\title{
Efficiency in Islamic vs. conventional banking: The role of capital and
}

\author{
liquidity \\ Mohammad Bitar ${ }^{\mathrm{a} \dagger}$, Kuntara Pukthuanthong ${ }^{\mathrm{b}}$, Thomas Walker ${ }^{\mathrm{c}}$

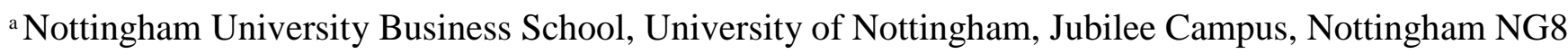 \\ 1BB, United Kingdom \\ ${ }^{\mathrm{b}}$ Department of Finance, University of Missouri, 419 Cornell Hall, Trulaske College of Business, \\ Columbia, MO 65211, United States. \\ ${ }^{\mathrm{c}}$ Department of Finance, Concordia University, 1455 Blvd. de Maisonneuve West, Montréal, QC H3G \\ 1M8, Canada. \\ ${ }^{\dagger}$ Corresponding author. Tel: +44 (0) 11574844 \\ E-mail addresses: mohammad.bitar@nottingham.ac.uk (M. Bitar), pukthuanthongk@missouri.edu (K. \\ Pukthuanthong), thomas.walker@ concordia.ca (T. Walker).
}

\begin{abstract}
We show that higher capital and liquidity ratios increase the efficiency of conventional and Islamic banks. Using conditional quantile regressions, we further show that the effect is stronger for highly efficient, small, highly liquid, and highly capitalized conventional banks. We also find that more capitalized and liquid banks were efficient during the 2008/2009 financial crisis and the Arab Spring. Our findings support the view that the constraints imposed by Shari'a law may widen the efficiency gap between the two bank types, at the expense of Islamic banks. Furthermore, our findings suggest that the efficiency of conventional banks not only depends on bank capital and liquidity, but also on the level of bank efficiency while the relationship is inconclusive for Islamic banks. These findings provide insight into how capital and liquidity can shape bank efficiency. They suggest that higher capital and liquidity buffers serve a constraint on policymakers and may function very differently depending on the level of bank efficiency.
\end{abstract}

JEL Classification: $\quad$ G21, G28, G29

Keywords: $\quad$ Capital, Liquidity, Efficiency, Conditional Quantile regressions 


\section{Introduction}

Although Shari' $a$-compliant banks ${ }^{1}$ account for only $1.5 \%$ of total assets in the worldwide banking sector (Abedifar et al., 2013; Bitar et al., 2017a), they have experienced tremendous growth over the last 30 years and currently account for US\$1.56 trillion of total assets of the worldwide banking sector (Islamic Financial Services Board (IFSB), 2018). Moreover, the total assets of Shari'a-compliant financial industry has reached a total of US\$2.05 trillion in 2017 (IFSB, 2018). The development of this sector can be explained by several factors including (i) the oil revenues of the Gulf countries, and (ii) the desire of the Muslim world to extend Shari'a laws to all economic activities. The global growth of the Islamic banking industry experienced a $4.3 \%$ expansion mainly located in Iran, Saudi Arabia, UAE, and Malaysia (IFSB, 2018). In addition, the Islamic banking market share has increased above $20 \%$ in several countries, reflecting its role as a promising new player along with conventional banks.

These features raise several concerns about the development of the Islamic banking industry. As a result, research has intensified to examine the effects of this sectoral development on bank risk (Zins and Weill, 2017), competition (Meslier et al. 2017), financial soundness (Bitar et al. 2017a, b), profitability (Mollah and Zaman, 2015; Mollah et al., 2016), and capital structure (Bitar et al., 2018; Bitar and Tarazi, 2019). Recent surveys (cf., Song and Oosthuizem, 2014; López-Mejía et al., 2014) show that although various countries are improving their legal, regulatory, and supervisory framework regarding Islamic banking activities, several challenges in terms of capital and liquidity persist and require further investigation. We focus on capital and liquidity because they represent the two main pillars suggested by the Basel III guidelines to create a more resilient banking system. While Ashraf et al. (2016) and Zins and Weill (2017) examine the effect of Basel II regulation and liquidity ratios on the stability of Islamic banks, we investigate the impact of holding higher capital and liquidity on their efficiency.

Empirical studies have reported mixed findings on the association between banking capital and the efficiency of conventional banks. Staub et al. (2010) find that when Brazilian banks hold more capital they are more cautious in terms of their risk behavior, which can be channeled into higher efficiency scores. Their findings are supported by Banker et al. (2010) and Hsiao et al. (2010) in Korean and Taiwanese

\footnotetext{
${ }^{1}$ This paper does not report the distinguishing characteristics of the Shari'a-compliant banking system. For detailed information on this topic, please refer to Khan (2010), Abedifar et al. (2013), and Beck et al. (2013).
} 
contexts, respectively. The authors argue that higher capital adequacy ratios reduce banks' portfolio risk, thus leading to safer and better credit risk practices and better performance of the banking system. Pessarossi and Weill (2015) also provide evidence of a positive association between capital and efficiency for banks operating in China, suggesting that shareholders require less incentive to take action against depositors if their stakes in the bank are larger. However, Berger and Di Patti (2006), Altunbas et al. (2007), and Lesanovska and Weill (2016) offer different views when examining banks in the US, in fifteen European countries, and in the Czech Republic, respectively. While Lesanovska and Weill (2016) find no association between capital and efficiency, the former two studies show that low capital ratios diminish agency costs and improve efficiency.

While the research cited above mainly focuses on the impact of capital on conventional bank efficiency, the effect of liquidity, which is considered a key novelty in Basel III, has rarely been discussed. Vazquez and Federico (2015) and Ashraf et al. (2016) provide evidence that shows that higher liquidity ratios improve bank stability in conventional and Islamic banks, respectively. However, the relationship between liquidity ratios and bank efficiency has not yet been examined in either bank type. In the conventional banking system, risk is channeled from lenders to borrowers while in the Islamic banking system, risk is shared between the two. Therefore, guidelines requiring banks to maintain higher liquid assets to reduce capital write-off and protect depositors are likely to be less of a concern for Islamic banks than for conventional banks.

Based on the studies reported above, we investigate whether capital and liquidity ratios affect the efficiency of conventional versus Islamic banks differently. To do this, we follow Barth et al. (2013) and employ two-stage data envelopment analysis (DEA). Specifically, we use an unbalanced panel of 4,123 bank-year observations over the 2005-2012 period. In a first step, we compute and compare the efficiency scores of conventional and Islamic banks following the methodology proposed by Johnes et al. (2014). Then, in a second step, we regress our efficiency scores on a series of proxies for capital and liquidity using conditional quantile regressions.

This paper provides empirical and operational contributions to the existing literature. At the methodological level, and in contrast to previous studies, we combine two nonparametric approaches, DEA and conditional quantile regressions, for two reasons. First, banking institutions are complex organizations 
and simple ratio analyses cannot capture the complete picture of efficiency for both bank types (Johnes et al., 2014; Bitar et al., 2017b). ${ }^{2}$ As a multifaceted concept, DEA is more effective in capturing bank efficiency as it computes efficiency scores by producing a range of outputs from a range of inputs. Second, while regulators produce a single set of capital and liquidity guidelines for the entire banking industry (including conventional and Islamic banks), we argue that banks need to consider their extant level of efficiency. Highly efficient banks may have adequate capital buffers to protect against liquidity stresses in the future. Thus, the marginal impact of increasing capital and liquidity on the efficiency of already highly efficient banks may be lower than it is for banks of low efficiency. Furthermore, highly efficient banks tend to be riskier and may have difficulties in raising capital on short notice. As such, they tend to hold higher capital and liquidity ratios than low-efficiency banks, which lowers the benefit of increasing their capital and liquidity. For Islamic banks, there are additional institutional factors that should be considered. Riskier activities on the asset side can increase liquidity mismatches between long-term investments (e.g. Mudharaba and Musharaka Profit Loss Sharing (PLS) contracts) and short term deposits (Zins and Weill, 2017). In addition, riskier activities are often based on PLS arrangements, which, in contrast to conventional banks' activities, do not require any surplus of capital. Thirdly, depositors or Investment Account Holders (IAHs) of Islamic banks agree to share profits and bear losses when they occur. As a result, any form of higher capital reserves to protect against liquidity shortages and gain depositors' confidence should be irrelevant under Shari'a law. For all these reasons, if highly efficient Islamic banks have riskier portfolios, then higher capital and liquidity ratios might have a different impact on their efficiency compared to conventional banks. Consequently, a conditional quantile regression approach is preferable over other approaches because it allows for the examination of a nonlinear efficiency relationship.

At the operational level, this study has important implications for the type of regulation that is appropriate for Islamic banks. Recent empirical studies have shown mixed results for the impact of regulation on bank risk. While Ashraf et al. (2016) report a positive association between liquidity and Islamic banks' stability, Weill and Zins (2017) find that Basel II penalizes the stability of Islamic banks

\footnotetext{
2 Another argument is provided by Johnes et al. (2014) who explain that accounting-based profitability and efficiency indicators, such as the return on assets, net interest margin, and cost-to-income ratio, are based on bank balance sheets and are often exposed to measurement errors due to differences in countries' accounting standards and on-/off-balance sheet issues. In this paper we do not criticize the use of financial ratios but rather argue that one financial indicator cannot capture the full picture of bank efficiency. Accordingly, an approach based on DEA is preferable.
} 
compared to conventional banks. In this study, we argue that if bank capital and liquidity influence the risk of Islamic banks, they will influence their efficiency as well (Lesanovska and Weill, 2016). Specifically, we extend previous studies comparing the efficiency of Islamic and conventional banks (Johnes et al., 2014; Bitar et al., 2017b) by examining (a) the dependence of efficiency on bank capital and liquidity and (b) how this dependence varies for banks with different extant levels of efficiency (using a quantile regression). If the higher capital and liquidity ratios imposed by conventional banking regulations are not compatible with the specificities of Islamic banks, such regulations might widen the efficiency gap between the two bank types at the expense of Islamic banks. This could have a negative effect on economic growth in countries where Islamic banks have a large market share.

The rest of this paper is organized as follows. Section 2 briefly reviews the literature, develops the hypotheses, and discusses the potentially nonlinear influence of capital and liquidity on bank efficiency. Section 3 discusses our methodology, presents the variables, and describes the data set. Section 4 discusses the quantitative results, including our descriptive statistics, conditional quantile regressions, and several robustness checks. Section 5 concludes.

\section{Background}

\subsection{Islamic banking and efficiency}

Prior literature on the efficiency of conventional and Islamic banks offers different views on whether Islamic banks are more or less efficient than conventional banks.

On one hand, several studies support the view that Islamic banks are likely to be more efficient based on four main arguments. First, Islamic banks' mark-up financing contracts are asset-backed and thus linked to the real economy, which makes them less exposed to losses related to speculative activities (derivatives and other conventional securities) that caused the 2008 financial crisis. Second, Islamic banks often face commercial pressure to pay competitive returns to IAHs to retain existing depositors and attract new ones. If return rates are not competitive enough, IAHs can withdraw funds and invest elsewhere. This pressure may discipline Islamic banks and make them more efficient (Farooq and Zaheer, 2015). Third, the managerial competency of Islamic banks has increased substantially to cover for disadvantages related to constraints imposed by Shari'a law. According to Johnes et al. (2014), in recent years, Islamic banks have 
increased their investment in staff training and in improving public knowledge of Islamic financial products. These measures have led to an enhanced reputation, a more positive bank experience, and greater demand for their products. Finally, Islamic banks may also be more efficient than conventional banks due to macroeconomic factors. For instance, Bitar et al. (2017b) suggest that oil revenues, the rapid economic development through the private banking sectors, the opening up of the banking sector to foreign competition, and the newly adopted financial reforms (in some countries) put pressure on Islamic banks. This pressure can be translated into new financial products and more spending on research and development, as well as on employee training to ensure efficiency in allocating resources and to enhance productivity.

On the other hand, various studies have argued that Islamic banks are less efficient than conventional banks for four main reasons. First, the reliance on the real economy can put Islamic banks at a disadvantage if financial distress hits the real economy (Bourkhis and Nabi, 2013). For instance, Nakheel. the property development arm of the investment company Dubai World, announced the rescheduling of more than $\$ 4$ billion of Islamic banks' Sukuks, which could have triggered a crisis for the Islamic banking system if Nakheel had faced bankruptcy. This incidence led Standard and Poor's “Islamic Finance Outlook” (2017) to question Islamic banks' dependency on real estate. Second, Shari'a law places constraints on investments and on several tools of risk management (Abedifaret al., 2013), and some Islamic banking products are not standardized (rather, they are tailor-made to fit specific clients). Johnes et al. (2014) argue that these factors generate greater administrative and operational costs. Furthermore, the development of Islamic banking products tends to be time consuming, as products require approval by the Shari'a board. Third, Islamic banks are often exposed to double regulatory standards. They not only need to comply with international regulations, such as the Basel Accords, but also with the Islamic Financial Services Board (IFSB) and the Accounting and Auditing Organization for Islamic Financial Institutions (AAOIFI) regulatory frameworks, which could increase the costs of their compliance at the expense of their efficiency scores (Bitar et al., 2017b). Finally, because they are smaller and less experienced, Islamic banks are less capable of benefiting from economies of scale than their conventional counterparts (Beck et al., 2013).

In the empirical literature, studies that compare the performance of conventional and Islamic banks often use profitability measures (Mollah and Zaman, 2015; Mollah et al., 2016) or efficiency measures 
(Beck et al., 2013; Johnes et al., 2014; Bitar et al., 2017b). In this review we focus on the three studies that examine the association between Islamic banks and efficiency, as they are more relevant to the present study.

Beck et al. (2013) employ various proxies of bank efficiency to compare 510 conventional and Islamic banks in 22 countries over the period 1999-2009. These indicators include the cost to income ratio, the overheads to assets ratio, and the loan loss reserves to gross loans ratio. Their findings vary substantially across countries. However, overall they show that Islamic banks are less cost-efficient and have higher intermediation costs than their conventional peers. They further show that large Islamic banks incur greater costs than large conventional banks. The authors interpret their findings based on the complexity of some Islamic banking products and on Islamic banks' young age compared to conventional banks.

While Beck et al. (2013) use accounting measures to proxy for bank efficiency, Johnes et al. (2014) use meta-frontier analysis to compute efficiency scores for conventional and Islamic banks. Their study covers 255 banks operating in countries where at least $60 \%$ of the population is Muslim. Their approach consists of computing a common efficiency frontier for the two bank types as well as two separate efficiency frontiers, one for each bank type. While the common frontier's results represent the operational business model, the specific frontiers' results represent the managerial competence of managers of the two bank types. Their results provide evidence that Islamic banks are less efficient than conventional banks when using a common frontier but more efficient when using specific efficiency frontiers. The authors explain this result by arguing that the operational business model puts Islamic banks at a disadvantage compared to conventional banks, but that the managers of Islamic banks make up for this disadvantage by improving their skills and enhancing public knowledge of their products.

Bitar et al. (2017b) use factors extracted from principal component analysis to assess the financial soundness of Islamic banks. They consider a sample of banks in 33 countries during the period 1999 to 2013. In comparison with the two previous studies, they construct an efficiency factor based on combinations of different efficiency measures to compare the two bank types. Their findings show that Islamic banks are more efficient than conventional banks. Specifically, they find that when banks are operating in a hybrid legal system or a more religious country, listed and mature Islamic banks are more efficient than their conventional counterparts. According to the authors, different factors can explain these 
findings. First, scale economies and activity diversification along with market discipline, strong monitoring, and supervision can explain the superior efficiency of mature and listed Islamic banks compared to conventional banks that meet these criteria. Second, in more religious countries and in countries with a hybrid legal system, Islamic banks are better recognized by the government and the general public (compared to how they are perceived in other countries). This recognition enables these banks to easily access the market, obtain resources, and sell Shari'a-compliant products. It also helps Islamic banks to avoid costs related to simultaneous compliance with different regulatory standards.

To summarize, the differences between the two bank types provide arguments in support of either higher or lower efficiency for Islamic banks compared to conventional banks. While Beck et al. (2013) find that Islamic banks are less efficient, Johnes et al. (2014) and Bitar et al. (2017b) show that Islamic banks are more efficient, due to internal factors, such as managerial skills, and external ones, such as market discipline and recognition by the government and general public.

\subsection{Tested hypotheses}

We propose four different hypotheses regarding the effect of higher capital and liquidity ratios on the efficiency of Islamic banks.

The first hypothesis (H.1) suggests that capital ratios negatively affect the efficiency of Islamic banks. The hypothesis relates to the fact that Islamic banks have to comply with Shari'a law and thus have a specific profile of deposits (Zins and Weill, 2017). For instance, Islamic banks use investment accounts in which depositors share profits with their banks but also bear losses when they occur. According to Shari'a law, IAHs are treated like investors, and thus protection of their initial capital and returns is not required. Such an arrangement can increase the moral hazard behavior of the managers of Islamic banks. These managers may seek more investment deposits, which provide them with leverage to engage in riskier activities - by relying on Mudharaba and Musharaka PLS contracts - and generate higher profits to satisfy shareholders at the expense of IAHs who bear any potential losses (Bitar et al., 2017b). This implicit agreement yields higher profits for shareholders while improving the reputation, salaries, and bonuses of the managers of Islamic banks. In other words, the investment accounts of Islamic banks may be used as leverage to maximize bank profits at the expense of bank IAHs and the bank's capital position. 
The second hypothesis (H.2) posits that capital ratios positively affect the efficiency of Islamic banks because at a practical level, Islamic banks often operate in dual banking systems and share the same market as conventional banks. Therefore, Islamic banks cannot always channel losses to IAHs because the latter might withdraw their funds, causing liquidity and solvency problems. To avoid potential losses and liquidity stress, they prefer to use mark-up based activities, such as Muraraba and Ijara contracts, instead of PLS contracts and tend to hold higher capital ratios (Zins and Weill, 2017). In addition, Islamic banks tend to compete with conventional banks by offering a competitive return on investments to IAHs, compared to the interest rates proposed by conventional banks, using their profit-smoothing reserves ${ }^{3}$ or by displacing their commercial risk. ${ }^{4}$ In so doing, Islamic banks can channel retained earnings from these reserves or capital to remunerate IAHs and thus maintain their confidence. There are two important implications for the efficiency of Islamic banks. First, increased returns on investment accounts attract more deposits and thus increase potential investments. Second, increased returns on Islamic bank investments (return on assets) can help the banks to build up additional reserves and capital, which can offset future losses. This practice can be used to attract more deposits by signaling a strong monitoring incentive to IAHs, since higher solvency ratios force banks to internalize the costs of their defaults. In addition, enhanced monitoring and screening of potential projects can be reflected in lower expectations of the projects' default, thus improving efficiency.

The subprime crisis shows that liquidity also plays a critical role in maintaining a resilient banking system, alongside capital requirements. Housa (2013) argues that liquidity buffers are likely to have an important impact on the funding structure and profitability of banks. Likewise, Altunbas et al. (2007) contend that liquidity is positively associated with the efficiency of conventional banks.

The third hypothesis (H.3) is that higher liquidity ratios negatively affect the efficiency of Islamic banks. Islamic banks face several challenges regarding their funding structure because of the Shari'a

\footnotetext{
${ }^{3}$ Profit Equalization Reserves (PER) are used to reduce or neutralize the profit payout fluctuations on investment deposits and by extension to create profit rates that are aligned with market rates of return on conventional deposits. Islamic banks can also use the Investment Risk Reserves (IRR) to cover losses that might occur from time to time and to grant a minimum level of return to their IAHs.

${ }^{4}$ Islamic banks can transfer the risk that arises from investments managed on behalf of IAHs to their own capital by adjusting the shareholders' share of profits. Such a situation often occurs when the IAHs' funds are invested in projects based on long term Murabaha or Ijara contracts at profit rates that no longer meet current market expectations. It could also occur due to market risk and credit risk where the Islamic bank intervenes to protect IAHs' returns from the poor performance of assets under its management (IFSB, 2005, p. 19).
} 
constraints imposed on their business model. For instance, Islamic banks lack a cross-border Islamic interbank money market (Abdullah, 2010) and short-term Shari'a-compliant liquidity instruments (Čihák and Hesse, 2010). They also cannot benefit from short-term financing provided by central banks (Beck et al., 2013) and cannot channel any liquidity surplus to conventional banks (Akhtar et al., 2011). Furthermore, Abdullah (2010) notes that "in some countries ... the legal framework for public debt and financing arrangements does not explicitly allow for the design and issuance of Islamic financial instruments" (p. 14). Therefore, Islamic banks possess higher liquidity buffers to protect against their weak liquidity infrastructure (Zins and Weill, 2017). In this respect, Hassan and Dridi (2010) argue that Islamic banks should be prudent when considering the Basel liquidity requirements, as the liquidity management of these banks is in its infancy. In addition, Rajhi (2013) explains that Islamic banks possess higher amounts of liquidity simply because they are inefficient at managing their own resources. Accordingly, Shari'a constraints may put Islamic banks at a disadvantage relative to their conventional counterparts and may have a negative effect on their efficiency.

Conversely, the fourth hypothesis (H.4) suggests that liquidity ratios are positively associated with the efficiency of Islamic banks. These banks may be advised to hold higher liquidity buffers and to engage in short term investments that reflect their liability side (Zins and Weill, 2017). Given that Shari'a law prohibits Islamic banks from relying on derivatives and hedging instruments, holding higher liquidity ratios can be important, especially in stress situations (to avoid liquidity problems) and even more so in cases where there is a high withdrawal risk. In addition, depositors as well as investors prefer to deal with banks that have a healthy ratio of liquid assets to deposits, as argued by Belanes and Hassiki (2012) and Johnes et al. (2014). Therefore, more efficient banks tend to hold higher liquidity ratios that can serve as a security mechanism to protect against capital write offs, expensive fire sales, and sudden needs to raise costly equity, which could negatively affect their efficiency scores.

Overall, the four hypotheses mirror the identity crisis faced by the Islamic banking industry. One might expect that under Shari'a law, PLS instruments — as the core of Islamic banking and finance — would dominate the activities of Islamic banks. However, non-PLS modes of finance, such as Murabaha and Ijara, predominate and these can require Islamic banks to hold higher capital and liquidity ratios instead of engaging in profitable activities. In addition, critics of Islamic banks argue that their practices raise doubts 
about their compliance with Shari'a law (Khan, 2010; Beck et al., 2013) and view their products simply as conventional products adapted or modified to be compliant with Islamic law. Having similar products to those of conventional banks places Islamic banks in competition with their conventional counterparts, forcing them to use smoothing reserves to reduce the risk of withdrawal and avoid liquidity stress. In addition, constraints imposed by Shari'a law may increase the opportunity cost of not using funds in projects that are more profitable. Finally, a different scenario to that described above may be expected for highly efficient Islamic banks that are more likely to engage in PLS activities. That scenario implies that higher capital and liquidity ratios would widen the efficiency gap between the two bank types. Table 1 presents a brief literature review and reports the four hypotheses on the impact of capital and liquidity on the efficiency of conventional and Islamic banks.

[Insert Table 1 around here]

\subsection{Capital, liquidity, and the level of bank efficiency}

Examining how the impact of capital and liquidity ratios on bank efficiency varies with the extant degree of bank efficiency has important policy implications. Regulators set capital and liquidity guidelines as a whole for the entire banking industry (including conventional and Islamic banks), without considering a bank's level of efficiency. Highly efficient banks may react differently to capital and liquidity ratios than less efficient ones for two reasons, resulting in two opposing hypotheses. First, highly efficient banks might hold less capital because being highly efficient provides them with the buffers needed to increase their capital in the future (Fiordelisi et al., 2011) and thus to avoid any liquidity problems (Zins and Weill, 2017), which could also explain why regulators may be more flexible with these banks in terms of capital requirements. Second, highly efficient banks may need to be highly capitalized and highly liquid because of their high risk (employed to maximize their profits), which may make it difficult for them to raise capital on short notice. In this case, regulators push banks to increase their capital with the amount of risk taken (Bitar et al., 2017b), while banks themselves prefer to hold additional capital ratios above the minimum capital requirements to avoid both regulatory sanctions and any costs associated with issuing fresh equity (Fiordelisi et al., 2011). In the case of Islamic banks, riskier activities in terms of investments in PLS contracts, such as Mudharaba and Musharaka, do not require any additional capital and liquidity to protect against liquidity exposures or to gain depositors' confidence. Therefore, if highly efficient Islamic banks 
have riskier portfolios, they may react differently to higher capital and liquidity than conventional banks. In the following sections, we explain the quantile regression methodology, which allows us to examine the potentially nonlinear effect of capital and liquidity on bank efficiency.

\section{Data and methodology}

\subsection{Data}

Our data derive from five main sources. First, we obtained bank-level financial characteristics for an unbalanced sample of 4,123 bank-year observations (3,380 bank-year observations for conventional banks and 743 bank-year observations for Islamic banks) for twenty-eight countries ${ }^{5}$ from 2005 to 2012 using the Bankscope database of Bureau Van Djik. For the sample construction, we followed the comparative literature on conventional and Islamic banks (Abedifar et al., 2013; Beck et al. 2013; Bitar et al. 2019). Our original sample includes 33 countries. We removed countries like Albania, Bosnia and Herzegovina, Cayman Islands, Oman, and Senegal because they do not have available information on at least two out of the three measures of capital, i.e., Tier 1 capital and capital adequacy. Banks without at least three continuous observations were excluded. In addition, we removed countries with data for fewer than four banks (Beck et al. 2013) as well as banks with negative regulatory ratios (Bitar et al. 2019). Second, we used the 2012 World Development Indicators database to control for macroeconomic conditions and financial development. Third, we manually collected information on capital adequacy and Tier 1 capital ratios from the annual reports and financial statements of Islamic banks (for which the information is not available in the Bankscope database). Fourth, we accessed the Pew Research Center and the World Fact Book to retrieve information about the legal system in each country. Finally, data on the Arab Spring were compiled from a previous study by Bitar et al. (2017b).

\subsection{Data envelopment analysis (DEA)}

We use DEA for several reasons. As discussed in the introduction, bank efficiency is a multifaceted concept and cannot easily be examined using simple ratio analyses (Johnes et al., 2014). Second, DEA is a nonparametric technique and does not require any distributional form of the error term, which makes it

\footnotetext{
${ }^{5}$ Specifically, our sample covers the following countries: Algeria, Bahrain, Bangladesh, Brunei, Egypt, Gambia, Indonesia, Iran, Iraq, Jordan, Kuwait, Lebanon, Malaysia, Mauritania, the Maldives, Pakistan, the Palestinian Territories, the Philippines, Qatar, Saudi Arabia, Singapore, Syria, Sudan, Tunisia, Turkey, the United Arab Emirates, the United Kingdom, and Yemen.
} 
more flexible than other performance measures employed in traditional regression analysis (Johnes et al., 2014; Mollah and Zaman, 2015). Finally, DEA frontiers allow banks to have different objectives, as each bank is compared only with banks of similar inputs and outputs.

We follow Johnes et al. (2014) and Bitar et al. (2017b) and compare conventional and Islamic banks with their own efficiency frontiers. ${ }^{6}$ The efficiency scores are estimated separately for each year (Johnes et al., 2014). Ceteris paribus, Sufian (2010) argues that polling data separately for each year is important in estimating efficiency scores for two reasons. First, in contrast to regressions, DEA efficiency scores reflect yearly observations for each bank and assume that each bank optimizes its own productivity. Second, because the banking environment is dynamic, a bank might be efficient in the first year but inefficient in the following year. Hence, a yearly best-practice frontier might reveal significant changes over time. Similar concerns may arise on a country level. However, we do not pool our data for each country because the rules under which Islamic banks (i.e., Shari'a principles) and conventional banks work are the same regardless of location. To construct the DEA efficiency frontier of conventional and Islamic banks, we consider an input-oriented technique rather than an output-oriented technique because banks are costminimizing institutions whose outputs are normally determined by external demand and other external factors that banking institutions cannot control. In addition, we use an input-oriented DEA with variable returns to scale, as proposed by Banker et al. (1984), to measure pure technical efficiency (PTE). While some of the empirical literature uses cost and profit efficiency to proxy for bank efficiency (Berger and Di Patti, 2006; Fiordelisi et al., 2011; Pessarossi and Weill, 2015), technical efficiency is often used when studying banking regulations (Barth et al. 2013, Ayadi et al. 2016) and when comparing conventional and Islamic banks (Johnes et al. 2014; Bitar et al. 2017b). Profit efficiency, which is a measure based on inputcost and output-revenue, might be more appropriate for studies that focus on conventional banks where the underlying objective is profit maximization. In contrast, the main objective of Islamic banks is unlikely to be cost minimization or profit maximization (Johnes et al. 2014; Bitar et al. 2017b).

\footnotetext{
${ }^{6}$ We argue that in contrast to conventional banks, Islamic banks are not only motivated by cost minimization and profit maximization, but rather that these banks endorse social values and ethical behaviour. Therefore, as long as Islamic banks are viewed to some extent as different in terms of their objectives and activities, a specific efficiency frontier for each bank type can be seen as more appropriate than a common efficiency frontier. More details about the distinguishing characteristics of specific versus common frontiers can be found in previous works, such as Johnes et al. (2014) and Bitar et al. (2017b).
} 


\subsection{DEA input-output definition}

The choice of inputs versus outputs is under debate in the efficiency literature. ${ }^{7}$ We employ a series of inputs and outputs as in previous studies. The inputs are: deposits and short-term funding (Hsiao et al., 2010; Belanes and Hassiki, 2012; Barth et al., 2013; Johnes et al., 2014), fixed assets (Sufian, 2010; Johnes et al., 2014), overhead as a proxy for general and administrative expenses, and loan loss provisions as a proxy of risk (Barth et al., 2013). With regards to the last input, we note that the efficiency literature is divided on the incorporation of loan loss provisions versus equity to control for a bank's risk exposure. On one hand, Johnes et al. (2014) propose using equity as an indicator of risk taking. They argue that data on loan loss provisions are more difficult to collect and may reduce the sample size because of data unavailability. On the other hand, Beck et al. (2013) point out that risk can be incorporated by including loan loss provisions in efficiency analyses. Ultimately, because of concerns about mixing flow and stock factors in bank inputs, we compute efficiency scores using three alternative input measures to control for bank risk. ${ }^{8}$ The outputs are: total loans (Hsiao et al., 2010; Staub et al., 2010; Barth et al., 2013; Johnes et al., 2014), other earning assets (Barth et al., 2013), and other operating income. Barth et al. (2013) argue that an important reason for including other operating income is to avoid penalizing banks that largely rely on nontraditional activities in their investment portfolio.

\subsection{Conditional quantile regressions}

Our sample covers 28 countries with heterogeneous characteristics. For example, small countries such as Lebanon and the Maldives are listed together with big countries such as the United Kingdom. Our sample is similar in its composition to the samples used by Andini and Andini (2014) in the sense that the sample countries have different levels of economic growth, legal systems, and degrees of oil dependence. Consequently, multiple linear regressions, such as OLS or GLS, that assume that standard errors are normally distributed do not hold in our study because our proxy for bank efficiency and many of our independent variables are not normally distributed (Andini and Andini, 2014). Looking at the unconditional distribution of bank efficiency scores in Figure 1 and the distribution of standard errors in Figure 2, there

\footnotetext{
7 Descriptive statistics for banks' inputs and outputs are available from the authors upon request.

${ }^{8}$ The three methods of controlling for bank risk among the inputs are: (i) including loan loss provisions, as mentioned above, (ii) replacing loan loss provisions with total equity, and (iii) not including any control for risk. The regression results are highly consistent across the three approaches.
} 
is clear evidence that our dependent variable does not follow a normal distribution. In Figure 1, the solid green line illustrates the normal distribution while the dashed red line represents the distribution of the efficiency proxy, which is not normally distributed. The Quantile-Quantile (Q-Q) plot (Figure 2) also shows significant deviation of the standard errors from the straight horizontal line, indicating that standard errors likewise do not follow a normal distribution. In addition to these two graphical illustrations, we perform a series of statistical tests. The Kolmogorov-Smirnov test for normality suggests that normality is rejected for our proxy of bank efficiency; the p-values for efficiency scores are less than 0.01. Cramer-von Mises and Anderson Darling tests report similar results. In addition, we compute the Jarque-Bera test for normality, which asymptotically approaches the $\chi^{2}$ distribution with two degrees of freedom and performs well with large data (number of observations $>2,000$ ). We find that our efficiency proxy has a critical value of $\chi_{0.05,2}^{2}=5.99$, thus confirming the graphical results that our efficiency scores are not normally distributed.

While previous studies focus on the mean value of the efficiency distribution, conditional quantile regressions estimate a whole set of quantile functions providing a richer description of the heterogeneous relationship among capital, liquidity, and bank efficiency (highly efficient versus less efficient). We follow Andini and Andini (2014) and use the quantile regression approach proposed by Koenker and Basset (1978). Conditional quantile regressions represent a generalization of median regression to other quantiles of the response variable (Koenker and Hallock, 2001). This approach is more robust to outliers and distributions with heavy tails. In addition, it helps avoid the restrictive assumption that the error terms are identically distributed at all points of the conditional distribution. The baseline quantile regression is given by:

$$
y_{i j t}=x_{i j t}^{\prime} \beta_{0}+\varepsilon \theta_{i j t} \text { with } \text { Quant }_{\theta}\left(y_{i j t}, x_{i j t}\right)=x_{i j t}^{\prime} \beta_{0}
$$

where $y_{i j t}$ is a measure of the pure technical efficiency of bank $i$ in country $j$ in year $t$. This variable is calculated by estimating the efficiency scores relative to each bank category's own efficiency frontier to ensure the robustness of our results (Johnes et al., 2014). In other words, Islamic (conventional) banks are 
compared to their own benchmark (i.e., the most efficient Islamic (conventional) banks in a given year). ${ }^{9}$ $x_{i j t}^{\prime}$ is a vector of exogenous variables, $\beta_{0}$ is the vector of coefficients to be estimated, and $\varepsilon$ is a vector of residuals. Quant $\theta\left(y_{i j t}, x_{i j t}\right)$ denotes the $\theta^{\text {th }}$ conditional quantile of $y_{i j t}$ given $x_{i j t}$. The $\theta$ th regression quantile, where $0<\theta<1$, solves the following problem:

$$
\begin{aligned}
& \min / \beta \frac{1}{n}\left\{\sum_{i, j, t: y_{i j t}>x_{i j t}^{\prime} \beta} \theta\left|y_{i j t}-x_{i j t}^{\prime} \beta\right|+\sum_{i, j, t: y_{i j t}<x_{i j t}^{\prime} \beta}(1-\theta)\left|y_{i j t}-x_{i j t}^{\prime} \beta\right|\right\} \\
& =\min / \beta \frac{1}{n} \sum_{j=1}^{n} \rho_{\theta} \varepsilon_{\theta i j t}
\end{aligned}
$$

where $\rho_{\theta}(\cdot)$, which is known as the 'check function', is defined as:

$\rho_{\theta}\left(\varepsilon_{i j t}\right)=\left\{\begin{array}{ll}\theta \varepsilon_{\theta i j t} & \text { if } \theta \varepsilon_{\theta i j t} \geq 0 \\ (\theta-1) \varepsilon_{\theta i j t} & \text { if } \varepsilon_{\theta i j t}<0\end{array}\right\}$

Accordingly, Equation (2) below is resolved using a linear programming approach. Following Buchinsky (1998), as one increases $\theta$ continuously from 0 to 1 , one marks the entire conditional distribution of $y_{i j t}$, conditional on $x_{i j t}{ }^{10}$

$$
Q\left(y_{i j t} \mid C A P_{-} L I Q_{i j t}\right)=x^{\prime}(\mathbf{C A P}, \mathbf{L I Q}, \mathbf{B C}, \mathbf{C C})_{i j t}+\varepsilon_{i j t}
$$

The exogenous vector $x_{i j t}^{\prime}$ include four groups: (i) capital and liquidity variables (CAP and LIQ), (ii) banklevel variables (BC), (iii) country-level variables including macroeconomic factors (CC), and (iv) interactions, cross-sectional, and time-series fixed-effect variables.

\subsection{Capital, liquidity, and other control variables}

As noted above, the vectors CAP and LIQ represent bank capital and liquidity ratios. The main methodological difference between our study and the prior literature on banking regulations is that we use

\footnotetext{
${ }^{9}$ Efficiency scores are also estimated relative to a common frontier that includes conventional and Islamic banks. The results are presented in section 4.3.4. However, this comparison gives an advantage to conventional banks as they are far more developed than Islamic banks (Johnes et al. 2014; Bitar et al. 2017b).

${ }^{10}$ We used the sqreq module of Stata 14.2 to run simultaneous conditional quantile regressions using a sample covering the period between 2005 and 2012 for a panel of 28 countries.
} 
bank-level variables instead of aggregate, country, and time-invariant measures of capital and liquidity. For instance, Barth et al. (2013) use time-invariant regulatory variables, which represent a critical limitation. Therefore, we collect bank-level data that cover 28 countries from 2005 to 2012. Our data set incorporates six main ratios to proxy for the impact of higher capital and liquidity on the efficiency of both bank types. We refer to the Bankscope database and consider the capital adequacy ratio, which is computed as Tier 1 capital plus Tier 2 capital divided by risk-weighted assets and off-balance-sheet exposures. We also consider the Tier 1 capital ratio, which is calculated as the sum of shareholders' funds and perpetual, noncumulative preference shares divided by risk-weighted assets and off-balance-sheet exposures. An important difference between the traditional (Basel) capital ratios and both capital adequacy and Tier 1 capital ratios is that Basel regulatory guidelines closely relate the level of bank capital to the underlying risk a bank faces, where the risk assessment is carried out by the bank itself. This self-assessment by banks may create incentives for banks to hide their real exposure to risk and to provide untruthful information about their capital adequacy position (Blum, 2008). In addition to the two capital risk-based measures mentioned above, we use the shareholders' equity ratio computed by dividing bank equity base by total assets (Abedifar et al., 2013; Vazquez and Federico, 2015). ${ }^{11}$ As for liquidity, we use three ratios. The first is the maturity match ratio computed by dividing a bank's liquid assets by its deposits and short-term funding. A higher value means a bank is more liquid. The second ratio is the ratio of liquid assets to assets. One important feature of this ratio is that it provides a quick picture of the proportion of liquidity available to pay for short-term obligations. Therefore, the ratio of liquid assets to assets is an indicator of bank liquidity. The third measure is the ratio of liquid assets to total deposits and short-term borrowing, which provides a general view of a bank's liquidity position by considering the amount of liquid assets available for borrowing in addition to deposits.

BC is the vector of bank portfolio characteristics. We control for bank size using the natural logarithm of total assets (Barth et al., 2013; Beck et al., 2013). We also use tangibility computed as the ratio of fixed assets to assets and activity diversification computed by dividing net loans by total earning assets (Abedifar et al., 2013; Beck et al., 2013). Finally, we investigate whether costs are positively or negatively associated

\footnotetext{
${ }^{11}$ Recent literature shows that the complexity of risk-weighted assets methodology could underestimate bank true risk exposure. To avoid any potential untruthful assessment related to the calculation of risk-weighted assets and by extension the bank's actual level of capital, we follow Bitar et al. (2016) and use a non-risk-based equity to assets ratio to further check the robustness of our results.
} 
with bank efficiency by employing the cost-to-income ratio, CIR. We anticipate that higher costs are negatively associated with bank efficiency (Beck et al., 2013).

$\mathbf{C C}$ is a vector of country-level variables used to control for macroeconomic conditions. We use the logarithm of GDP per capita and GDP growth to measure economic development. For instance, a higher value of GDP growth reflects higher financial stability (Anginer et al., 2014; Vasquez and Federico, 2015). We also use the inflation rate, Inflation. Kasman and Yildirim (2006) show that higher inflation may create incentives for banks to compete through excessive branch networks. Lee and Hsieh (2013) argue that with higher inflation rates, banks tend to charge customers more, resulting in higher interest rates and bank profits. However, such behavior might be followed by less demand for loans and more expensive loan reimbursement, leading to higher default rates (Koopman et al., 2009). Boyd et al. (2001) consider inflation a signal for an undeveloped market and banking system. Our last variable, following Abedifar et al. (2013) and Bitar et al. (2017b), is a measure of legal systems, Legal, which controls for the degree of religiosity.

In addition, we include country-year dummy variables to control for time and country heterogeneity. Finally, we follow Anginer et al. (2014) and Bitar et al. (2017b) and cluster at the bank level for two reasons. First, some countries have a much larger number of observations than other countries in the sample. Second, we only have twenty-eight countries. Therefore, clustering at the country level might create biased results. All explanatory variables are winsorized at the $1 \%$ and $99 \%$ levels to mitigate the effect of outliers. Definitions and data sources for all variables are provided in Table A1 in the Appendix.

\section{Empirical results}

\subsection{Descriptive statistics}

Table 2 Panel A shows that, on average, Islamic banks are more efficient than conventional banks thus confirming earlier findings by Johnes et al. (2014) and Bitar et al. (2017b). While the former explain the superiority of Islamic banks by a higher level of managerial competency, the latter attribute it to their greater involvement in low-risk governmental infrastructure projects. Table 2 Panel A also shows that Islamic banks are more capitalized and more liquid than conventional banks (although in the case of liquidity, this result does not hold true for all liquidity ratios). ${ }^{12}$ For example, the Tier 1 capital ratio differs

\footnotetext{
${ }^{12}$ See Table A2 in the Appendix for a correlation matrix for our variables.
} 
significantly with a mean value of $27.83 \%$ for Islamic banks and $16.92 \%$ for conventional banks. The maturity match ratio has a mean of $74.99 \%$ for Islamic banks and $49.47 \%$ for conventional banks. The higher capital and liquidity ratios for Islamic banks can be partly explained by the weak Islamic interbank money market, the prohibition of derivatives and debt instruments, and the absence of a lender of last resort, leading Islamic banks to hold larger capital and liquidity reserves (Zins and Weill, 2017). Another reason for holding higher capital ratios is the desire to smooth the profits of investment account holders to reduce the risk of withdrawals and avoid liquidity mismatches (Bitar et al., 2017a). Regardless of the bank type, we notice that the capital ratios of banks in our sample largely exceed the minimum capital requirements imposed by the Basel III Accord. Finally, the $t$-tests and Wilcoxon rank tests confirm the significant differences in capital and liquidity between the two bank types.

As for the control variables, the results show that conventional banks are larger but have lower tangible assets than Islamic banks, which is in line with previous studies (Beck et al., 2013; Bitar et al., 2017b; Zins and Weill, 2017). The ratio of net loans to total earning assets shows that Islamic banks engage in traditional financing activities to a greater extent than do conventional banks, reflecting the constraints imposed by Shari'a law regarding investments in other earning assets (Abedifar et al., 2013). The cost to income ratio shows that Islamic banks have higher costs than conventional banks because they are younger and less experienced and thus cannot benefit from economies of scale. Moreover, Islamic banks invest more in screening and monitoring of some of their PLS activities, such as Mudharaba and Musharaka, to reduce their clients' morally hazardous behavior. In addition, Shari'a law prohibits many of the facilities available to conventional banks, such as using derivatives, debt, and hedging instruments. Finally, Table 2, Panel B presents the number of conventional and Islamic banks across 28 countries.

[Insert Table 2 around here]

\subsection{Main results}

As shown in the previous section, our univariate tests suggest that there are significant differences in the efficiency, capital, and liquidity of conventional versus Islamic banks. In this section, ${ }^{13}$ we first compare

\footnotetext{
${ }^{13} \mathrm{We}$ also estimate the regression for the 5th, 10th, 90th, and 95th quantiles. We obtain similar results but do not present them here due to the relatively small number of observations in these quantiles.
} 
the efficiency of conventional and Islamic banks, after which we examine the impact of higher capital and liquidity ratios on the efficiency of the two bank types. To do this, we use an Islamic bank dummy variable, Islamic, which equals 1 for Islamic banks and 0 for conventional banks, to capture efficiency differences between the two bank types. We also interact Islamic with the capital and liquidity ratios to examine their effect on the efficiency of Islamic banks using the following equation:

$$
\begin{gathered}
Q\left(\text { Efficiency }_{i j t} \mid \text { CAP_LIQ }_{i j t}\right)=\alpha+\varphi \times \text { Islamic }_{i}+\vartheta \times \mathbf{C A P}_{-} \mathbf{L} \mathbf{I Q}_{\mathbf{i j t}}+\vartheta^{*} \times \mathbf{C A P}_{-} \mathbf{L I} \mathbf{Q}_{\mathbf{i j t}} \times \text { Islamic }_{i} \\
+\beta \times \mathbf{B C}_{\mathbf{i j t}}+\gamma \times \mathbf{C C}_{\mathbf{j t}}+\sum_{j=1}^{N} \delta_{j} \times \text { Country }_{j}+\sum_{t=1}^{T} \mu_{t} \times \text { Time }_{t}+\varepsilon_{i j t}
\end{gathered}
$$

First, we examine the relation between capital ratios and the efficiency of Islamic and conventional banks. Table 3, Panel A shows that, in the capital ratio model, Islamic banks are more efficient than conventional banks at the $1 \%$ significance level across all quantiles when using a specific efficiency frontier for each bank type. These results are similar to those obtained by Johnes et al. (2014) and Bitar et al. (2017b) but different from those provided by Beck et al. (2013). As for the impact of capital ratios on the efficiency of Islamic and conventional banks, our findings in Panel A show that higher capital ratios (both risk-based capital ratios and traditional capital ratios) have a significant positive effect on the efficiency of conventional banks ( $\vartheta_{\mathrm{CAP}}$ is positive and significant). This effect of capital is also positive (but less pronounced) for Islamic banks $\left(\left[\vartheta_{\mathrm{CAP}}+\vartheta_{\text {inter }}^{*}\right]\right.$ is positive and significant). The findings suggest that the capital effect is stronger for highly efficient conventional banks (Models 3, 6, and 9) while we observe no consistent trend in the capital effect across the efficiency quantiles of Islamic banks. A Wald test confirms the significant differences for the effect of capital ratios on the lower and upper quantile of the efficiency distribution of conventional banks but suggests no significant difference across quantiles for Islamic banks. $^{14}$

Overall, the findings in Panel A support our second hypothesis suggesting that, for Islamic banks, higher capital ratios reduce displaced commercial risk by affording banks the opportunity to offer competitive rates by smoothing IAHs' returns. In addition, higher capital ratios can be considered as a

\footnotetext{
${ }^{14}$ Some tests report non-available (N/A) results because Stata does not perform the Wald test and the linear combination test when the number of observations in the lower and the upper quantile of the efficiency distribution is not equal.
} 
credible monitoring incentive not only to assure IAHs, but also to attract new depositors. Furthermore, higher capital ratios can enable Islamic banks to build up additional reserves to deal with future default and to issue new equity at a lower cost. As for the stronger capital effect on highly efficient conventional banks, we interpret this finding as indicating that these banks may have riskier portfolios or are more likely in need of raising capital on short notice (which can be costly) and thus prefer to hold higher capital ratios to avoid equity costs and regulatory sanctions. For Islamic banks, a risky portfolio means greater reliance on Mudharaba and Musharaka PLS contracts, and thus the capital effect (and, by extension, the need to raise additional capital) is less important, as depositors share profits and losses with Islamic banks. Finally, despite the positive effect of capital on the efficiency scores of Islamic banks, this effect appears to be less prominent than it is for conventional banks. This implies that higher capital ratios enlarge the efficiency gap between the two systems, especially for highly efficient banks. The less pronounced effect may be related to the fact that holding higher capital ratios does not affect Islamic banks as strongly because they share profits and losses with depositors and thus capital is no longer essential to protect depositors. The weaker effect may also result from the way banks compute their capital ratios. Zins and Weill (2017) argue that Basel II may not influence Islamic banks because risk-weighted asset methodologies consider the risks of only conventional banks. Finally, in many countries Islamic banks may be exposed to double regulatory standards. For instance, they may have to comply with regulatory guidelines imposed by the Islamic Financial Services Board (IFSB) and the Accounting and Auditing Organization for Islamic Financial Institutions (AAOIFI) but also with Basel guidelines, which could increase their compliance costs at the expense of their efficiency scores relative to their conventional counterparts (Bitar et al., 2017b).

\section{[Insert Table 3 around here]}

Table 3, Panel B corroborates the results of Panel A in showing that Islamic banks are more efficient than conventional banks at the $1 \%$ significance level across all quantiles when using a specific efficiency frontier for each bank type. As for the effect of liquidity ratios on the efficiency of Islamic and conventional banks, Panel B shows that higher liquidity ratios have a significant, positive effect on the efficiency of conventional banks $\left(\vartheta_{\mathrm{LIQ}}\right.$ is positive and significant in six out of nine models) and a positive but less pronounced effect on the efficiency of Islamic banks ( $\left[\vartheta_{\mathrm{LIQ}}+\vartheta_{\text {inter }}^{*}\right]$ is positive and significant but only in models 1 to 3 ). In addition, we find that the liquidity effect is stronger for highly efficient conventional 
banks (Models 3, 6, and 9) but there is no consistent trend across the efficiency quantiles of Islamic banks. The Wald test shows a marginally significant difference between the effect of liquidity ratios on the lower and upper quantile of the efficiency distribution of conventional banks, but no difference for Islamic banks.

Overall, these findings lend support to the fourth hypothesis by showing that higher liquidity ratios help avoid liquidity mismatches especially since Shari'a law imposes a severe constraint on the liquidity risk management of Islamic banks. These banks lack a powerful Islamic interbank money market. They have limitations regarding the development of short-term financing instruments and are not allowed to deal with debt instruments and derivatives. In addition, Islamic banks suffer from a disparity in standards and accounting methods (IFSB and AAOIFI regulatory guidelines versus Basel guidelines). For these reasons, they are motivated to hold higher liquidity ratios, which can help them resist liquidity shortage and isolate them from the externalities of the financial crisis at the same time, which, in turn, can be translated into higher efficiency scores. However, the liquidity effect is less pronounced for Islamic banks than for conventional banks, suggesting that higher liquidity ratios widen the efficiency gap between the two bank types. While the constraints imposed by Islamic law on Islamic banks can explain their higher liquidity ratios, inefficiency in managing resources could be another reason for maintaining higher liquidity buffers. If Islamic banks are unable to engage in profitable long term projects because they rely on short term financing and cannot benefit from debt instruments, then the opportunity cost of holding liquidity buffers is higher and may have a penalizing effect on their efficiency scores.

As for the control variables, bank size shows that larger banks are more efficient, which is thought to result from economies of scale, experience, and reputation (Beck et al., 2013; Bitar et al., 2017b). We also find that tangible assets have a negative impact on bank efficiency. Therefore, a higher share of non-earning assets on bank balance sheets decreases efficiency scores because of the opportunity cost that arises from investing in fixed assets instead of loans, derivatives, and other types of securities. Moreover, we find that a higher proportion of net loans to total earning assets could harm the efficiency of a bank. This harm could be explained by these banks' weak credit risk management or their higher dependence on loan/financing activities instead of on investments in other types of earning assets. Finally, bank cost clearly shows that higher cost reduces bank efficiency at successive quantiles and for all models. Bitar et al. (2017a) explain that the inability to control operating expenses has a negative influence on bank efficiency. As for 
macroeconomic conditions, we find that GDP growth is positively associated with bank efficiency, whereas GDP per capita and inflation are rarely significant. In sum, economic growth improves banks' efficiency. Our results are consistent with the findings of Johnes et al. (2014) and Bitar et al. (2017b).

\subsection{Robustness checks}

\subsubsection{The role of bank size}

To provide some additional insight, we explore whether the impact of bank capital and liquidity differs between small and large banks. While Beck et al. (2013) and Bitar et al. (2017a) find that the financial soundness of Islamic banks can vary depending on bank size, Zins and Weill (2017) report no significant difference for the impact of Basel II on Islamic bank risk between small and large banks. To shed additional light on this issue, we split our sample of Islamic and conventional banks according to the median ${ }^{15}$ of the logarithm of total assets in each bank category. Similar to Eq. (5), we include the same bank $^{16}$ and country-level characteristics in addition to country-year fixed effects. Employing conditional quantile regressions, the results in Table 4, Panel A suggest that, in general, higher capital ratios have a significantly positive effect on the efficiency of small conventional banks ( $\vartheta_{C A P}$ is positive and significant) and a positive but less pronounced effect on the efficiency of small Islamic banks $\left(\left[\vartheta_{\mathrm{CAP}}+\vartheta_{\text {inter }}^{*}\right]\right.$ is positive and significant). We also observe a positive and significant effect on large Islamic banks, but only at the lowest efficiency quantile. Furthermore, the effect of capital on the efficiency of both bank types appears to be stronger for small banks than for large ones. Finally, for small banks, we find that the capital effect is stronger for highly efficient conventional banks than highly efficient Islamic banks (Model 6) but shows no consistent trend across the efficiency quantiles of Islamic banks. We explain these findings by the fact that small banks cannot benefit from governmental bailouts and from lenders of last resort in the same fashion as large and systemically important banks. Smaller banks hold higher capital ratios because they are less recognized and reputable and thus may experience difficulties in raising new equity during periods of financial stress (Zins and Weill, 2017). In addition, they cannot benefit from economies of scale and diversification (Abedifar et al., 2013). Small banks may also be more prudent in their investment

\footnotetext{
${ }^{15}$ Based on the median value of each bank category, Islamic banks are classified as small banks when LnTA $\leq 14.0650$ and as large banks when LnTA $>14.0650$. Likewise, conventional commercial banks are considered small when LnTA $\leq 14.4783$ and large when LnTA > 14.4783.

${ }^{16} \mathrm{We}$ split Islamic and conventional banks according to their asset size; thus, we no longer control for LnTA in Table 4.
} 
decisions because they tend to be younger and less experienced than large banks, which could explain the positive effect of capital on their efficiency scores. The same arguments also apply to small Islamic banks. In addition, Islamic banks engage in profit smoothing mechanisms to provide IAHs with competitive returns, which could explain the strong positive effect of capital on the lower and medium quantile of the efficiency distribution of capital (on the lower and medium efficiency quantiles of small Islamic banks and on the low efficiency quantile of large Islamic banks). In other words, less efficient Islamic banks are likely to use their capital reserves to smooth IAHs' returns to reduce the risk of withdrawal and to sustain competition with conventional banks, which could be translated into higher efficiency scores. As for the efficiency gap, it seems to be driven mainly by small conventional and Islamic banks. Small and highly efficient Islamic banks may decide to engage more in PLS activities. In addition, these banks cannot compute their own risk-weighted assets using internal rating (Zins and Weill, 2017). This methodology is often used by large banks, which can afford its costs and the complexity of its application. Finally, small Islamic banks are more exposed to the costs related to double regulatory standards than large Islamic banks, for which the regulatory authorities tend to be more flexible in terms of enforcing capital requirements.

[Insert Table 4 around here]

As for liquidity, Table 4, Panel B suggests that liquidity increases the efficiency of small conventional and Islamic banks, although this positive effect is only significant when using the maturity match ratio for Islamic banks. The findings also suggest that the liquidity effect is stronger for highly efficient, small conventional banks (Models 11 and 12). On one hand, small banks are often more exposed to liquidity mismatches, have less access to interbank money markets, and cannot benefit from lenders of last resort. Small Islamic banks, on the other hand, need to hold additional reserves to smooth IAH returns and prevent sudden withdrawals. Yet, holding higher liquidity ratios can also be interpreted as poor liquidity management and can increase the opportunity cost since holding higher liquidity buffers reduces opportunities for engaging in profitable investment projects. This can explain the insignificant effect of the remaining two liquidity ratios on the efficiency of small Islamic banks. It can also explain the efficiency gap resulting from small Islamic banks holding higher liquidity ratios. 
4.3.2. High liquidity versus low liquidity and high capitalization versus low capitalization banks

We split the sample into high liquidity and low liquidity banks according to the median of the maturity match ratio ${ }^{17}$ to examine whether the association between capital and efficiency of the two bank types is driven by either of these subgroups. Table 5, Panel A shows that at successive quantiles, capital ratios are positively associated with the efficiency of highly liquid conventional banks (Models 1-3). However, when we examine conventional banks with low liquidity, we observe a positive effect only for the upper quantile of the efficiency distribution (Model 6). As for Islamic banks, higher liquidity ratios show a positive effect on the efficiency of highly liquid Islamic banks, but this effect is only seen when using the shareholders' equity ratio and less pronounced than the equivalent effect for conventional banks. These findings are similar to those of Berger et al. (2016) who refer to a risk absorption theory where highly capitalized conventional banks are more liquid. In addition, Weill and Zins (2017) explain that Islamic banks tend to hold higher capital ratios to overcome liquidity stress and reduce withdrawal risk. This could partially explain the more pronounced effect of capital ratios on the efficiency of highly liquid conventional and Islamic banks along with the fact that capital is a credible monitoring incentive that serves not only to assure IAHs, but also to attract new depositors.

To check the robustness of the findings in Table 5, Panel A, we split the sample into banks of high and low capitalization according to the median of the shareholders' equity ratio ${ }^{18}$ and examine whether the association between the liquidity and efficiency of Islamic banks is driven by either of these subgroups. Panel B shows that liquidity is positively associated with the efficiency of highly capitalized conventional banks. The same result is obtained for highly capitalized Islamic banks, but the effect is less pronounced. In addition, the Wald test continues to provide evidence of significant differences between the effect of capital ratios on the lower and upper quantile of the efficiency distribution of conventional banks.

\footnotetext{
${ }^{17}$ Based on the median value of each bank category, Islamic banks are classified as having low liquidity when the maturity match ratio is $\leq 33.95$ and as being highly liquid when the maturity match ratio is $>33.95$. Likewise, conventional commercial banks are considered as having low liquidity when the maturity match ratio is $\leq 33.88$ and as being highly liquid when the maturity match ratio is $>33.88$.

${ }^{18}$ Islamic banks are classified as having low capitalization when the shareholders' equity ratio is $\leq 15.82$ and as highly capitalized when the shareholders' equity ratio is $>15.82$. Likewise, conventional commercial banks are considered as having low capitalization when the shareholders' equity ratio is $\leq 10.84$ and high capitalization when the shareholders' equity ratio is $>$ 33.88 .
} 
In brief, the findings in Panels A and B suggest that highly liquid and highly capitalized banks have a stronger effect on efficiency, although this effect tends to be less pronounced for Islamic banks.

[Insert Table 5 around here]

4.3.3. The effect of higher capital and liquidity on the efficiency of Islamic banks during the financial crisis and the Arab Spring

As further evidence, we now examine the effect of holding higher capital and liquidity ratios on the efficiency of Islamic banks during the global financial crisis and the Arab Spring distress period. To do this, we develop the following quantile regression model, shown in the first instance for the global financial crisis period:

$$
\begin{aligned}
& Q\left(\text { Efficiency }_{i j t} \mid C_{\text {f }} \text { PP_LIQ }_{i j t}\right) \\
& =\alpha+\varphi \times \text { Islamic }_{i}+\vartheta \times \mathbf{C A P} \_\mathbf{L I} \mathbf{Q}_{\mathrm{ijt}}+\vartheta^{*} \times \mathbf{C A P} \_\mathbf{L I Q}_{\mathrm{ijt}} \times \text { Islamic }_{i}+\emptyset^{*} \times G L O B A L \\
& +\emptyset^{* \prime} \times \text { Islamic }_{i} \times G L O B A L+\varphi^{*} \times \mathbf{C A P} \mathbf{P}_{-} \mathbf{L} \mathbf{Q}_{\mathrm{ijt}} \times G L O B A L+\varphi^{* \prime} \times \mathbf{C A P}_{-} \mathbf{L I} \mathbf{Q}_{\mathrm{ijt}} \\
& \times G L O B A L \times \text { Islamic }_{i}+\beta \times \mathbf{B C}_{\mathbf{i j t}}+\gamma \times \mathbf{C C}_{\mathbf{j t}}+\sum_{j=1}^{N} \delta_{j} \times \text { Country }_{j}+\varepsilon_{i j t}
\end{aligned}
$$

Anginer et al. (2014) use data from Laeven and Valencia (2008) to examine the relationship between bank capital and risk in the crisis period. However, after examining an updated version of Valencia and Laeven's (2012) data on banking crisis periods, we find only a small number of countries in our sample that were reported as being affected between 2005 and 2012. Therefore, we decide to follow Abedifar et al. (2013) and Beck et al. (2013) instead and consider 2008-2009 as the global financial crisis period. We add a crisis dummy, GLOBAL, which equals 1 for the period 2008-2009, and 0 otherwise. We interact GLOBAL with Islamic, with $C A P \_L I Q$, and with both variables simultaneously $\left(C A P \_L I Q \times G L O B A L \times I s l a m i c\right)$. We investigate whether Islamic banks were more efficient during the global financial crisis as well as whether the effect of holding higher capital and liquidity ratios on their efficiency scores remains the same. The results in Table 6, Panels A and B show that both Islamic and conventional banks were less efficient during the global crisis $\left(\varnothing^{*}\right.$ and $\emptyset^{*}+\emptyset^{* \prime}$ are negative and significant in both the capital and liquidity models). The two panels also respectively show that more capitalized and more liquid conventional banks were more efficient during the global subprime crisis $\left(\vartheta+\varphi^{*}\right.$ is positive and significant). The effect of 
capital and liquidity also appears to be positive and significant for Islamic banks during the crisis period, especially when using the shareholders' equity and the maturity match ratios $\left(\vartheta+\varphi^{*}+\varphi^{* \prime}\right.$ is positive and significant). It thus appears that higher capital and liquidity ratios helped both bank types to be more efficient during the subprime crisis, as also shown in other studies (Beck et al., 2013; Bitar et al., 2017a). Finally, we notice that the positive effect of bank capital is stronger for high-efficiency (as opposed to lowefficiency) conventional banks while the differential effect across efficiency quantiles for Islamic banks is inconclusive.

[Insert Table 6 around here]

In a second step, we examine whether the results persist during the Arab Spring. Following Ghosh (2016) and Bitar et al. (2016), we invoke a dummy variable, Arab spring, which equals 1 if a country was severely affected by the Arab Spring, and 0 otherwise. ${ }^{19}$ This variable replaces GLOBAL in Equation (6). The findings, reported in Table 7, Panels A and B, show that the Arab Spring does not have a significant effect on the efficiency of the two bank types $\left(\emptyset^{*}\right.$ and $\emptyset^{*}+\emptyset^{* \prime}$ are insignificant in both the capital and liquidity models). The results in both panels continue to show that more capitalized and more liquid conventional banks are more efficient when replacing the global subprime crisis with the Arab Spring $(\vartheta+$ $\varphi^{*}$ is positive and significant). The effect of capital and liquidity also appears to be positive and significant for Islamic banks during the Arab Spring when using the shareholders' equity and the maturity match ratios $\left(\vartheta+\varphi^{*}+\varphi^{* \prime}\right.$ is positive and significant). Therefore, banks with higher capital and liquidity ratios appear to be more efficient not only in periods of financial distress, but also in periods of political distress.

[Insert Table 7 around here]

\subsubsection{Alternative risk factors in bank inputs}

As an additional sensitivity test, we replace loan loss provisions with total equity to control for risk in bank inputs (Johnes et al., 2014; Bitar et al., 2017b). The results in Table 8 (Models 1-3) are consistent

\footnotetext{
${ }^{19}$ We define the Arab Spring as the period of political distress, revolutions, and armed rebellions that resulted in severe economic and financial instability in the Arab world.
} 
with those in prior tables. Capital ratios and liquidity ratios are positively associated with the efficiency of conventional banks. This effect is also positive (although less pronounced) for Islamic banks.

In a second step, we exclude total equity from the bank inputs because some may argue that equity is already considered part of bank capital and thus cannot be included in both the dependent and independent variables. As a result, we no longer control for the risk measure in the bank inputs. Employing conditional quantile regressions, Table 8 (Models 4-6) shows that the results remain significant. For instance, capital adequacy and shareholders' equity ratios have a positive effect on the efficiency of conventional banks. The effect of these variables on the efficiency of Islamic banks is also positive. As for liquidity, the three proxies show a positive effect on the efficiency of conventional banks at successive quantiles (Models 46). Liquidity ratios also have a positive effect on the efficiency of Islamic banks. While capital and liquidity ratios tend to have a stronger effect on high-efficiency (as opposed to low-efficiency) conventional banks, there is no consistent trend across the efficiency quantiles for Islamic banks. The Wald test confirms these findings, indicating a significantly different effect of some capital and liquidity ratios between the lower and upper quantile of the efficiency distribution of conventional banks, but there is no such difference for Islamic banks. The finding that the effects of capital and liquidity are weaker for highly efficient Islamic banks than for highly efficient conventional banks once again confirms the presence of an efficiency gap at the expense of Islamic banks, at least for banks in the highest efficiency quantile.

[Insert Table 8 around here]

\subsubsection{Excluding developed countries}

Another important concern is that our sample includes Islamic banks operating in advanced economies, such as the United Kingdom and Singapore. For instance, one may argue that the United Kingdom and Singapore are international financial centers and differ widely from the other countries in our sample. This difference is important given that DEA efficiency scores are sensitive to outliers. Accordingly, banks in these countries may be heterogeneous and different in terms of their business model, regulation, and supervision compared to banks in the rest of the developing world. Therefore, we first exclude the United Kingdom from our sample and re-compute efficiency scores for both conventional and Islamic banks. In a second step, in addition to the United Kingdom, we exclude Singapore and re-compute the 
efficiency scores. Our results are presented in Table 8 (Models 7-12) and show even more robust findings. Higher capital and liquidity ratios are positively associated with the efficiency of conventional banks, especially highly efficient ones. The effects of capital and liquidity are also positive for Islamic banks, although there is no conclusive evidence of a differential effect across the efficiency quantiles. ${ }^{20}$

\subsection{Other estimation techniques}

\subsubsection{Capital and liquidity changes}

Since we study the effect of capital and liquidity on the efficiency of Islamic banks, it would be interesting to examine how temporal changes in capital and liquidity can affect changes in Islamic banks' efficiency. For instance, Barth et al. (2013) suggest that a bank's efficiency level can be affected by changes in regulatory reforms. We refer to Barth et al. (2013) and study changes in capital and liquidity ratios because Islamic banks are often more capitalized and more liquid than their conventional counterparts. Therefore, it is important to study the effect of year-to-year changes in capital and liquidity buffers in addition to the effect of their absolute values on efficiency. We use first-difference estimation with yearto-year changes (corresponding to the sample period) for all dependent and independent variables. We delete 2005 from the sample because it lacks sufficient observations. We also lose several bank-year observations because of the first-difference estimation. As a result, the final sample contains observations for six of eight years.

The findings, presented in Table 9 (Models 1-3), provide several new insights. First, in almost all models, Islamic banks are not significantly different from their conventional counterparts in terms of yearto-year efficiency changes, suggesting that one bank type is actually following or mimicking the financial performance of the other type. Second, while changes in capital and liquidity ratios continue to show a positive effect on conventional bank efficiency changes, the same changes appear to have no significant effect on efficiency changes for Islamic banks. For conventional banks, the changes in capital requirements are likely to represent the passage from Basel I to Basel II and more recently to the Basel III capital guidelines. These changes appear to have a strong positive effect on the efficiency changes of conventional

\footnotetext{
${ }^{20}$ In comparison with the rest of our sample, where Islamic banks operate in a dual banking system, Iran and Sudan have a fully compliant Shari'a banking system. Therefore, in addition to excluding developed countries, we also excluded two developing countries, i.e., Iran and Sudan to further ensure the robustness of our findings. The results remain unchanged and further confirm our previous findings. This point has been brought to our attention thankfully by one of the referees.
} 
banks. For Islamic banks, however, changes in capital guidelines do not seem to have a significant effect on efficiency changes. While Basel capital guidelines are explicitly designed for conventional banks, Islamic banks often take time to adapt these guidelines to account for some of their specificities. In addition, the IFSB often publishes specific and adapted guidelines for Islamic banks following every new guideline published by the Basel Committee on Banking and Supervision (BCBS). These publications could explain the insignificant effect of capital changes on the efficiency changes of Islamic banks. Finally, changes in capital ratios appear to widen the efficiency gap between the two bank types by favoring conventional banks over Islamic ones.

As for liquidity ratios, we find little evidence that changes in liquidity ratios are associated with changes in efficiency scores. This lack of correlation can be explained as follows: (i) in contrast to the capital ratio reforms imposed by Basel I and Basel II, the regulatory authorities did not exert any mandatory guidelines that required banks to increase their liquidity ratios, ${ }^{21}$ thus, the liquidity ratios for both bank types remained constant during the studied period; and (ii) Basel III is the first guideline to require banks to hold liquidity buffers. However, these new liquidity buffers are being implemented in the period between 2015 and 2021, a period that we do not cover in this study.

[Insert Table 9 around here]

\subsubsection{Alternative regression analysis}

As additional sensitivity tests, Table 9 (Models 4-6) employs three alternative econometric specifications and standard error corrections. First, we use truncated regressions to address any biases related to the upper and lower distribution of observations for the dependent variable. We also correct for the heteroscedasticity of standard errors using a White procedure. Second, we employ a random effect, generalized least squares (GLS) regression and use two methods for correcting standard errors: i) a bootstrapping technique with a random resample of 100 banks from our main sample, and ii) clustering standard errors at the bank level. Importantly, the estimated coefficients on capital and liquidity load positively and significantly on the efficiency scores of the two bank types in almost all estimations and

\footnotetext{
${ }^{21}$ Basel III implemented the liquidity coverage ratio in January 2015 and the net stable funding ratio in January 2018 . As for Islamic banks, only a guidance principle on liquidity risk management was implemented in 2013.
} 
models; however, this positive effect is more pronounced for conventional banks than for Islamic ones, indicating that our main results are unaffected by the use of different estimation techniques.

\subsubsection{Additional and alternative control variables and instrumental variable approach}

We complement our analysis and address the issue of potentially omitted variables by including a series of macro variables in our models. We refer to Barth et al. (2013) and use regulatory requirements, capital stringency, overall supervisory power, average tenure of supervisors, and strength of external audit to control for regulation, supervision, and monitoring. In addition, we add two variables to represent (i) the total percentage banking share of the three largest banks in a country, and (ii) the Islamic banking share in a country. The results in Table 10 (Models 1-3) show that almost all explanatory variables maintain their signs and significance. Furthermore, the Wald test shows that the significant difference between the effect of capital and liquidity ratios on the lower and the upper quantiles of the efficiency distributions of conventional banks remains unchanged.

\section{[Insert Table 10 around here]}

We also control for possible endogeneity concerns by emphasizing the important role of the regulatory environment when examining the impact of capital and liquidity on the efficiency of Islamic banks. To address the endogeneity concern, we use: (i) lagged values of the capital and liquidity ratios, and (ii) an instrumental variables (IV) approach, which consists of two-stage regressions.

The literature reports mixed views regarding the use of lagged (Demirgüç-Kunt et al., 2013; Anginer and Demirgüç-Kunt, 2014) versus non-lagged (Banker et al., 2010; Hsiao et al., 2010; Barth et al., 2013) independent variables to examine the impact of banking regulation on bank risk and performance. In a first step, we hypothesize that capital and liquidity ratios may take one year to show their pronounced effect. In addition, a one-year lag of capital and liquidity reduces any concerns about endogeneity. Therefore, we lag our capital and liquidity ratios by one year to examine the robustness of our results. Table 10 (Models 46) reports similar results, thereby confirming our earlier findings.

The second method of dealing with endogeneity involves using an IV approach. First, IV regresses each of our six proxies of the capital and liquidity ratios on our instruments and on the other regressors reported in the baseline models. Second, the predicted values of the various capital and liquidity ratios 
replace these ratios in the baseline models. In this study, we use the Freedom House's economic environment for the media index and Djankov et al's (2007) creditor rights index as instruments for the three capital ratios. We use the Political Regime Characteristics and Transitions of Polity IV project's durability of political regimes measure and Ashraf et al.'s (2016) leverage ratio as instruments for the three liquidity ratios. We use these measures because they capture the institutional environment, which plays a key role in shaping the financial development of economies. Moreover, we argue that it is unlikely that any of these measures has a direct effect on banking efficiency today. Instead, they may affect bank performance through their impact on banking capital and liquidity.

We follow Barth et al. (2009) and conduct an $F$-test of the excluded exogenous variables in the firststage regressions. The null hypothesis of the test is that our instrument does not explain cross-sectional differences in regulatory capital guidelines and measures. We reject the null hypothesis at the $1 \%$ level in almost all models. The results of the first-stage regressions generally show that our instruments are good determinants of the capital and liquidity ratios. The results of the second-stage regressions are reported in Table 10. We use different estimation techniques. In Model 7 we use a two-stage least squares regression, and in Model 8 we use the generalized method of moments. Both the Sargan and Hansen's J tests of overidentifying restrictions are statistically insignificant, suggesting that the instruments are valid in both estimations. The second-stage regression results show clear evidence of a positive and significant association among capital, liquidity, and bank efficiency in almost all models and across different estimation techniques. The same effect is also positive but less pronounced for the efficiency of Islamic banks. These results provide additional support for our earlier findings and suggest that our findings are not driven by endogeneity.

\subsubsection{Computing efficiency scores based on a common frontier}

Johnes et al. (2014) and Bitar et al. (2017b) find that Islamic banks are more efficient than conventional banks only when each bank type is compared to its own specific efficiency frontier. In this subsection, we re-compute efficiency scores using a common frontier for the two bank types and examine whether Islamic banks are more efficient than conventional banks. ${ }^{22}$ Defenders of the common frontier

\footnotetext{
22 The results for the higher efficiency scores of one bank type over the other type can be affected by the choice of a common or a specific efficiency frontier. We are grateful to one of the referees for bringing this point to our attention.
} 
approach argue that Islamic banks compete with conventional banks and thus have similar customers. In addition, many conventional banks have recently opened Islamic windows or subsidiaries and offer some Islamic banking products, suggesting that both bank types are similar, especially in a competitive environment. The results are presented in Table 11 and show the following: Firstly, Islamic banks are not significantly more efficient than conventional banks, except at the upper quantile of the efficiency distribution. This finding is in line with Johnes et al. (2014) and Bitar et al. (2017b) who argue that a common frontier comparison cannot distinguish between managerial incompetence and the rules under which a bank operates (conventional or Shari'a) as sources of inefficiency, which could explain the insignificant results. A specific frontier comparison, however, makes it possible to distinguish between the effects of managerial competence and the operational business model on bank efficiency. Accordingly, the fact that the result changes from being insignificant (with a common frontier) to being in favor of Islamic banks (with specific frontiers), suggest that the managers of Islamic banks are particularly efficient, in terms of skills and knowledge mobilization of their products, given the rules by which they are constrained. Secondly, capital and liquidity ratios are positively associated with the efficiency of conventional banks, especially highly efficient ones. Thirdly, capital and liquidity are positively associated with the efficiency of Islamic banks. Fourthly, the capital effect appears to be most pronounced for the lower quantile of the efficiency distribution of Islamic banks, while for conventional banks, it is most pronounced for the upper quantile of the efficiency distribution. Finally, the results remain unchanged after excluding the UK and Singapore from the sample.

\section{[Insert Table 11 around here]}

\section{Conclusions}

We have explored the effect of holding higher capital and liquidity ratios on the efficiency of conventional and Islamic banks, as well as whether this effect differs between less efficient and more efficient banks using conditional quantile regressions. Our results suggest that capital and liquidity ratios are positively associated with the extant efficiency of the two bank types. However, this positive effect appears to be less pronounced for Islamic banks, indicating that higher capital and liquidity ratios widen the efficiency gap between the two bank types in favor of conventional banks. Furthermore, a quantile regression approach suggests a nonlinear effect of capital and liquidity on bank efficiency; the efficiency 
gap tends to widen at the upper tail of the efficiency distribution. We consequently support the view that the effect of capital and liquidity depends not only on the bank type, but also on the level of bank efficiency. Finally, our results suggest that more capitalized and more liquid banks were also more efficient during the global financial crisis and the Arab Spring. Our results are robust when using first-difference conditional quantile regressions, an IV approach, and other estimation techniques.

Our findings reflect the nature of Islamic banks' business model and their novelty as a new player in the banking industry. Islamic banks can benefit from depositors' investment accounts to engage in risky PLS or mark-up financing activities. As a result, they prefer to hold higher capital ratios in addition to smoothing reserves in case of project default. They also tend to hold higher liquidity ratios to avoid liquidity mismatches between long-term investments and weak short-term debt (financing) infrastructure due to constraints imposed by Shari'a law. These specific features can be translated into more prudent investment decisions and greater monitoring incentives to reduce the risk of withdrawal and assure competitive returns to investment account holders, which could explain the positive effect on their efficiency. This conclusion stands for small, highly liquid, and highly capitalized Islamic banks. While Zins and Weill (2017) conclude that Basel II widened the risk gap between conventional and Islamic banks in favor of the former, our findings add to the debate by showing that higher capital and liquidity ratios extend the efficiency gap between the two bank types. It appears that the tendency for Islamic banks to hold significant buffers of capital and liquidity results from their specificities in term of PLS activities and constraints imposed by Shari'a law. These constraints can enlarge the efficiency gap with respect to their conventional peers due to the opportunity cost that arises from not using their funds in projects that are more profitable.

This study has three important implications for the ongoing debate between regulators and policy makers on the development of the Islamic banking industry. First, higher capital and liquidity ratios increase the efficiency of conventional banks more than they increase the efficiency of Islamic banks, especially when both bank types are already highly efficient. This situation could put Islamic banks at a disadvantage in countries with a strong reliance on Basel capital and liquidity requirements. Second, imposing higher capital and liquidity ratios could reduce the overall bank efficiency and economic growth in countries where the Islamic banking sector is considered too big to be ignored. Third, capital and liquidity effects are more pronounced for highly efficient banks, which imply a complex relationship between capital and liquidity 
on one hand and the level of bank efficiency on the other. Finally, while the literature argues that banking regulations improve conventional banks' efficiency, Islamic regulatory organizations should use Islamic financial principles and concepts to create their own set of ratios rather than following the traditional banking regulations. However, we do not call upon Islamic banks to escape existent regulations; rather we believe that adapted capital and liquidity guidelines proposed by the IFSB are welcomed and can serve as a cornerstone for more detailed guidelines that not only consider the particularities of Islamic banks, but also the nonlinear relationship between capital/liquidity and bank efficiency. 


\section{References}

Abdullah, D.V., 2010. Liquidity management in institutions offering Islamic financial services. Second Islamic Financial Stability Forum.

Abedifar, P., Molyneux, P., Tarazi, A., 2013. Risk in Islamic banking. Review of Finance 17, 2035-2096.

Akhtar, M.F., Ali, K., Sadaqat, S., 2011. Factors influencing the profitability of Islamic banks of Pakistan, International Research Journal of Finance and Economics 66, 125-132.

Altunbas, Y., Carbo, S., Gardner, E., Molyneux, P., 2007. Examining the relationship between capital, risk and efficiency in European banking. European Financial Management 13, 49-70.

Andini, M., Andini, C., 2014. Finance, growth and quantile parameter heterogeneity. Journal of Macroeconomics 40, 308-322.

Anginer, D., Demirgüç-Kunt, A., 2014. Bank capital and systemic stability. Policy Research Working Paper No. 6948, The World Bank, Washington, DC.

Anginer, D., Demirgüç-Kunt, A., Zhu, M., 2014. How does bank competition affect systemic stability? Journal of Financial Intermediation 23, 1-26.

Ashraf, D., Rizwan, M.S., L'Huillier, B., 2016. A net stable funding ratio for Islamic banks and its impact on financial stability: An international investigation. Journal of Financial Stability 25, 47-57.

Ayadi, R., Ben Naceur, S., Casu, B., Quinn, B., 2016. Does Basel compliance matter for bank performance? Journal of Financial Stability 23, 15-32.

Bank for International Settlements, 2013. Basel III: the liquidity coverage ratio and liquidity risk monitoring tools. Basel Committee on Banking Supervision.

Bank for International Settlements, 2014. Basel III: the net stable funding ratio. Basel Committee on Banking Supervision.

Banker, R.D., Chang, H., Lee, S., 2010. Differential impact of Korean banking system reforms on bank productivity. Journal of Banking \& Finance 34, 1450-1460.

Banker, R.D., Charnes, A., Cooper, W.W., 1984. Some models for estimating technical and scale efficiencies in data envelopment analysis. Management Science 30, 1078-1092.

Barth, J.R., Lin, C., Lin, P., Song, F., 2009. Corruption in banking lending to firms: Cross-country micro evidence on the beneficial role of competition and information sharing. Journal of Financial Economics 91, 361-388.

Barth, J.R., Lin, C., Ma, Y., Seade, J., Song, F., 2013. Do bank regulation, supervision and monitoring enhance or impede bank efficiency? Journal of Banking \& Finance 37, 2879-2892.

Beck, T., Demirgüç-Kunt, A., Merrouche, O., 2013. Islamic vs. conventional banking: business model, efficiency and stability. Journal of Banking \& Finance 37, 433-447.

Belanes, A.N., Hassiki, S., 2012. Efficiency in Islamic and conventional banks: A comparison analysis in the MENA region. Bankers, Markets \& Investors 120, 36-49.

Berger, A.N., Bouwman, C.H.S., Kick, T.K., Schaeck, K., 2016, Bank liquidity creation following regulatory interventions and capital support. Journal of Financial Intermediation 26, 115-141.

Berger, A.N., Di Patti, E., 2006. Capital structure and firm performance: a new approach to testing agency theory and an application to the banking industry. Journal of Banking \& Finance 30, 1065-1102.

Bitar, M., Madiès, P., Taramasco, O., 2017a. What makes Islamic banks different? A multivariate approach. Economic Systems 41, 215-235.

Bitar, M., Hassan, M.K., Hippler, W.J., 2018. The determinants of Islamic bank capital decisions. Emerging Markets Review 35, 48-68.

Bitar, M., Tarazi, A., 2019. Creditor rights and bank capital decisions: Conventional vs. Islamic banking. Journal of Corporate Finance 55, 69-104. 
Bitar, M., Hassan, M.K., Walker, T., 2017b. Political systems and the financial soundness of Islamic banks. Journal of Financial Stability 31, 18-44.

Bitar, M., Saad, W., Benlemlih, M., 2016. Bank risk and performance in the MENA region: The importance of capital requirements, Economic Systems 40, 398-421.

Blum, J.M., 2008. Why Basel II may need a leverage ratio restriction. Journal of Banking \& Finance 32, 16991707.

Bourkhis, K., Nabi, M., 2013. Islamic and conventional banks' soundness during the 2007-2008 financial crisis. Review of Financial Economics 22, 68-77.

Boyd, J.H., Levine, R., Smith, B.D., 2001. The impact of inflation on financial sector performance. Journal of Monetary Economics 47, 221-248.

Čihák, M., Hesse, H., 2010. Islamic banks and financial stability: An empirical analysis, Journal of Financial Services Research 38, 95-113.

Demirgüç-Kunt, A., Detragiache, E., Merrouche, O., 2013. Bank capital: lessons from the financial crisis. Journal of Money, Credit and Banking 45, 1147-1164.

Djankov, S., McLiesh, C., Shleifer, A., 2007. Private credit in 129 countries. Journal of Financial Economics 84, 299-329.

Farooq, M., Zaheer, S., 2015. Are Islamic banks more resilient during financial panics? IMF Working Paper, WP/15/41.

Fiordelisi, F., Marques-Ibanez, D., Molyneux, P., 2011. Efficiency and risk in European banking. Journal of Banking \& Finance 35, 1315-1326.

Ghosh, S. 2016. Political transition and bank performance: How important was the Arab Spring? Journal of Comparative Economics 44, 372-382.

Global financial development report (GFDR), 2014. Financial inclusion. International Bank for Reconstruction and Development, The World Bank., Washington, DC.

Hassan, M., Dridi, J., 2010. The effects of the global crisis on Islamic and conventional banks: a comparative study. IMF Working Paper, WP/10/201.

Housa, F., 2013. Basel III and the introduction of global liquidity standards. www.deloitte.com.

Hsiao, H., Chang, H., Cianci, A.M., Huang, L., 2010. First financial restructuring and operating efficiency: evidence from Taiwanese commercial banks. Journal of Banking \& Finance 34, 1461-1471.

Islamic Financial Services Board (IFSB), 2005. Capital adequacy standard for Institutions (other than Insurance Institutions) offering only Islamic Financial Services, Islamic Financial Services Board, Malaysia.

Islamic Financial Services Board (IFSB), 2018. Islamic Financial Services Industry Stability Report, Kuala Lumpur, Malaysia: Islamic Financial Services Board.

Johnes, J., Izzeldin, M., Pappas, V., 2014. A comparison of the performance of Islamic and conventional banks 2004 to 2009. Journal of Economic Behavior \& Organization 103, S93-S107.

Kasman, A., Yildirim, C., 2006. Cost and profit efficiencies in transition banking: the case of new EU members. Applied Economics 38, 1079-1090.

Khan, F., 2010. How Islamic is Islamic banking? Journal of Economic Behavior \& Organization 76, 805-820.

Koenker, R., Basset, G., 1978. Regression quantiles, Econometrica 46, 33-50.

Koenker, R., Hallock, K., 2001. Quantile regression. Journal of Economic Perspectives 15, 143-156.

Koopman, S.J., Kraussl, R., Lucas, A., Monteiro, A.B., 2009. Credit cycles and macro fundamentals. Journal of Empirical Finance 16, 42-54.

Laeven, L., Valencia, F., 2008. Systemic banking crises: A new database. IMF Working Paper, WP/08/224.

Lee, C., Hsieh, M., 2013. The impact of capital on profitability and risk in Asian banking. Journal of International Money and Finance 32, 1-31. 
Lesanovska, J., Weill, L., 2016. Does greater capital hamper the cost efficiency of banks? A bi-causal analysis. Comparative Economic Studies 58, 409-429.

López-Mejía, A., Aljabrin, S., Awad, R., Norat, M., Song, I., 2014. Regulation and supervision of Islamic banks. IMF Working Paper, WP/14/219.

Meslier, C., Risfandy, T., and Tarazi, A., 2017. Dual market competition and deposit rate setting in Islamic and conventional banks, Economic Modelling 63, 318-333.

Mollah, S., Hassan, K., Al-Farooque, O., and Mobarek, A., 2016. The governance, risk-taking, and performance of Islamic banks. Journal of Financial Services Research 51, 195-219.

Mollah, S., Zaman, M., 2015. Shari'ah supervision, corporate governance, and performance: conventional vs. Islamic banks. Journal of Banking \& Finance 58, 418-435.

Pessarossi, P., Weill, L., 2015. Do capital requirements affect bank efficiency? Evidence from China. Journal of Financial Stability 19, 119-127.

Rajhi, W., 2013 Islamic banks and financial stability: A comparative empirical analysis between MENA and Southeast Asian countries, Région et Développement 37, 150-177.

Song, I., Oosthuizem, C., 2014. Islamic banking regulation and supervision: survey results and challenges. IMF Working Paper, WP/14/220.

Standard \& Poor's (2017) Islamic finance outlook 2017.

Staub, R.B., Da Silva e Souza, G., Tabak, B.M., 2010. Evolution of bank efficiency in Brazil: a DEA approach. European Journal of Operational Research 202, 204-213.

Sufian, F., 2010. The impact of risk on technical and scale efficiency: empirical evidence from the China banking sector. International Journal Business Performance Management 12, 37-71.

Valencia, F., Laeven, L., 2012. Systemic banking crises database: An update. IMF Working Paper, WP/12/163.

Vazquez, F., Federico, P., 2015. Bank funding structures and risk: evidence from the global financial crisis. Journal of Banking \& Finance 61, 1-14.

Zins, A., Weill, L., 2017. Islamic banking and risk: The impact of Basel II. Economic Modelling 64, 626-637. 


\section{Tables}

Table 1

$\underline{\text { Brief literature review (and hypotheses) on the effect of capital and liquidity on bank efficiency }}$

Reported empirical literature on conventional banks (and prediction on Islamic banks)

Results (expected)

Panel A: Capital ratios and bank efficiency

Berger and Di Patti (2006); Altunbas et al. (2007); Goddard et al. (2010)

Capital ratios negatively affect the efficiency of conventional banks

Fiordelisi et al. (2011); Chortareasa et al. (2012); Staub et al. (2010); Banker et al. (2010); Barth et al. (2013); Pasiouras et al. (2015)

Islamic banks need to comply with the Shari'a law; they have a specific target of depositors; managers benefit from PLS arrangements; they engage in riskier activities; they prefer higher leverage (less capital) to increase efficiency

Islamic banks use mark-up activities instead of PLS activities; they possess reserves to smooth profits and provide competitive profit rates to their customers; they build-up additional capital buffers to improve their efficiency

Panel B: Liquidity ratios and bank efficiency

Altunbas et al. (2007); Johnes et al. (2014); Belans and Hassiki, 2012; Chortareasa et al. (2012)

Islamic banks face liquidity challenges related to constraints imposed by the Shari'a law; they have weak liquidity instruments and weak interbank money market which could be negatively associated with their efficiency

Islamic banks are advised to hold higher liquidity buffers and to engage in short-term investments; they are prohibited from dealing with debt and derivative instruments; liquidity buffers serve as a security mechanism and an indicator of a healthy liquidity Capital ratios positively affect the efficiency of conventional banks H.1: Capital ratios negatively affect the efficiency of Islamic banks

H.2: Capital ratios positively affect the efficiency of Islamic banks

Liquidity ratios positively affect the efficiency of conventional banks

H.3: Liquidity ratios negatively affect the efficiency of Islamic banks

H.4: Liquidity ratios positively affect the efficiency of Islamic banks 
Table 2

General descriptive statistics for commercial and Islamic banks

Panel A. Descriptive statistics for bank- and country-level control variables

\begin{tabular}{|c|c|c|c|c|c|c|c|c|c|c|c|c|c|c|c|c|}
\hline \multirow{2}{*}{ Variables } & & \multicolumn{7}{|c|}{ Conventional banks } & \multicolumn{6}{|c|}{ Islamic banks } & \multirow{2}{*}{$\begin{array}{l}\text { t-test } \\
\text { (p-value) }\end{array}$} & \multirow{2}{*}{$\begin{array}{l}\text { Wilc-test } \\
\text { (p-value) }\end{array}$} \\
\hline & & \multicolumn{2}{|l|}{$\mathrm{N}$} & \multirow{2}{*}{$\begin{array}{l}\text { Mean } \\
5712\end{array}$} & Median & STD & $10^{\text {th }}$ & $90^{\text {th }}$ & \multicolumn{2}{|c|}{$\mathrm{N} \quad$ Mean } & Median & STD & $10^{\text {th }}$ & $90^{\text {th }}$ & & \\
\hline \multicolumn{2}{|c|}{ Efficiency (loan loss provision) } & \multicolumn{2}{|c|}{3048} & & 52.34 & 23.64 & 30.03 & 100 & 583 & 76.36 & 86.15 & 26.17 & 36.54 & 100 & $0.00 * * *$ & $0.00 * * *$ \\
\hline \multicolumn{2}{|c|}{ Efficiency (no control for risk) } & \multicolumn{2}{|c|}{3334} & 50.19 & 44.65 & 23.9 & 23.74 & 93.73 & 743 & 70.54 & 73.35 & 28.37 & 27.25 & 100 & $0.00 * * *$ & $0.00 * * *$ \\
\hline \multicolumn{2}{|c|}{ Efficiency (shareholders' equity) } & \multicolumn{2}{|c|}{3334} & 58.61 & 54.61 & 22.6 & 32.04 & 100 & 743 & 85.11 & 96.41 & 19.45 & 52.76 & 100 & $0.00 * * *$ & $0.00 * * *$ \\
\hline \multicolumn{2}{|c|}{$\begin{array}{l}\text { Tier1 capital } \\
\text { The }\end{array}$} & \multicolumn{2}{|c|}{1763} & 16.91 & 13.8 & 11.96 & 8.5 & 26.7 & 526 & 27.83 & 18.11 & 28.16 & 9.71 & 60.5 & $0.00 * * *$ & $0.00 * * *$ \\
\hline Capital adequacy & & 225 & & 20.23 & 16.45 & 13.26 & 11.26 & 31.29 & 583 & 29.95 & 19 & 31.96 & 11.63 & 61.9 & $0.00 * * *$ & $0.00^{* * * *}$ \\
\hline Shareholders' equity & & 354 & & 14.58 & 10.84 & 13.04 & 5.25 & 26.63 & 869 & 26.75 & 15.82 & 25.78 & 6.07 & 73.7 & $0.00 * * *$ & $0.00 * * *$ \\
\hline Maturity match & & 348 & & 49.47 & 33.88 & 58.04 & 13.03 & 92.98 & 818 & 74.99 & 33.95 & 139.36 & 11.12 & 155. & $0.00 * * *$ & 0.7 \\
\hline Liquid assets to assets & & 353 & & 32.12 & 26.00 & 21.76 & 9.76 & 65.24 & 868 & 27.79 & 22.27 & 20.19 & 6.78 & 56.4 & $0.00 * * *$ & $0.00 * * *$ \\
\hline Liquid assets to total $\mathrm{d}$ & osits & 251 & & 37.67 & 29.46 & 30.04 & 11.64 & 70.7 & 401 & 42.72 & 28.1 & 55.58 & 6.89 & 76.5 & $0.07 *$ & $0.05^{*}$ \\
\hline Size & & 354 & & 14.57 & 14.45 & 2.03 & 12.08 & 17.25 & 869 & 13.85 & 14.07 & 1.98 & 11.32 & 16.3 & $0.00 * * *$ & $0.00 * * *$ \\
\hline Tangibility & & 343 & & 1.64 & 1.05 & 1.93 & 0.15 & 3.64 & 838 & 3.45 & 1.71 & 6.19 & 0.11 & 7.39 & $0.00 * * *$ & $0.00 * * *$ \\
\hline Activity diversification & & 345 & & 55.11 & 57.33 & 23.75 & 20.93 & 84.24 & 815 & 56.7 & 65.04 & 29 & 6.93 & 88.8 & 0.15 & $0.00 * * *$ \\
\hline ROAA & & 353 & & 1.2 & 1.14 & 2.14 & -0.08 & 3.02 & 862 & 1.18 & 1.16 & 6.66 & -3.01 & 5.3 & 0.93 & 0.47 \\
\hline CIR & & 346 & & 58.15 & 51.82 & 35.3 & 27.76 & 88.23 & 793 & 71.69 & 51.7 & 81.35 & 27.44 & 98.9 & $0.00 * * *$ & $0.08^{*}$ \\
\hline OVERTA & & 350 & & 2.44 & 2.03 & 1.56 & 0.83 & 4.75 & 857 & 3.35 & 2.4 & 2.59 & 1.01 & 6.95 & $0.00 * * *$ & $0.00 * * *$ \\
\hline Legal system & & 27 & & 0.49 & 0 & 0.53 & 0 & 1 & 27 & 1.02 & 1 & 0.5 & 0 & 2 & & \\
\hline GDP per capita & & 27 & & 8.82 & 8.62 & 1.44 & 7.05 & 10.64 & 27 & 8.79 & 8.83 & 1.41 & 6.86 & 10.6 & & \\
\hline GDP growth & & 27 & & 4.02 & 4.63 & 3.58 & 0.12 & 7.5 & 27 & 4.54 & 5.1 & 4.08 & -1.51 & 8.34 & & \\
\hline Inflation & & 27 & & 5.84 & 4.65 & 5.15 & 2.03 & 10.7 & 27 & 7.87 & 5.44 & 7.88 & 1.65 & 17.2 & & \\
\hline Panel B. Break & own of the & umbe & $\mathrm{ro}$ & onventi & and is & c banks a & $28 \mathrm{co}$ & s, over & the 200 & 12 peri & iod. & & & & & \\
\hline Country & $\begin{array}{l}\text { Conventi } \\
\text { banks (\# }\end{array}$ & & & $\begin{array}{l}\text { nic banks } \\
\text { 3s) }\end{array}$ & Countr & & $\begin{array}{l}\text { Conven } \\
\text { banks ( }\end{array}$ & $\begin{array}{l}\text { nal } \\
\text { (Bs) } \\
\end{array}$ & $\begin{array}{l}\text { Islamic } \\
\text { (\# IBs) }\end{array}$ & & Country & & $\begin{array}{l}\text { Convent } \\
\text { banks (\# }\end{array}$ & & $\begin{array}{l}\text { Islamic banks } \\
\text { (\# IBs) }\end{array}$ & \\
\hline Algeria & 13 & & 1 & & Kuwait & & 6 & & 7 & & Singapore & & 11 & & 1 & \\
\hline Bahrain & 10 & & 17 & & Lebano & & 27 & & 3 & & Sudan & & & & 11 & \\
\hline Bangladesh & 20 & & 3 & & Malays & & 24 & & 15 & & Syria & & 5 & & 2 & \\
\hline Brunei & 3 & & 1 & & Maldiv & & 3 & & 1 & & Tunisia & & 14 & & 2 & \\
\hline Egypt & 21 & & 2 & & Maurit: & & 6 & & 1 & & Turkey & & 23 & & 3 & \\
\hline Gambia & 5 & & 1 & & Pakista & & 21 & & 6 & & United Arab E & nirates & 16 & & 10 & \\
\hline Indonesia & 62 & & 2 & & Palestir & an territories & 3 & & 1 & & United Kingdo & & 126 & & 4 & \\
\hline Iraq & 4 & & 2 & & Philipp & & 25 & & 1 & & Yemen & & 4 & & 3 & \\
\hline Iran & & & 10 & & Qatar & & 5 & & 3 & & Total (banks) & & 477 & & 119 & \\
\hline Jordan & 11 & & 3 & & Saudi $A$ & rabia & 9 & & 3 & & & & & & & \\
\hline
\end{tabular}

Notes: This table presents descriptive statistics on the efficiency of commercial and Islamic banks, a series of capital and liquidity ratios, and various bank- and country-level variables. Our sample contains 4,123 bank-year observations for the period from 2005 to 2012. Efficiency (loan loss provision) denotes efficiency scores calculated relative to each bank's specific efficiency frontier where loan loss provisions are used as a risk factor; Efficiency (no control for risk) denotes banks' efficiency scores calculated relative to each bank's specific efficiency frontier where the risk factor is excluded from the efficiency inputs; Efficiency (total equity) denotes efficiency scores calculated relative to each bank's specific efficiency frontier where total equity are is used as a risk factor; Tierl capital represents the Basel II Tier1 regulatory ratio. This ratio is calculated by dividing a bank's Tier1 capital ratio by its risk weighted assets; Capital adequacy is the total capital ratio, also called the capital adequacy ratio. This ratio is calculated by dividing a bank's Tier1 and Tier2 capital ratio by its risk weighted assets; Shareholders' equity is the equity to assets traditional non-risk based capital ratio; Maturity match is the ratio of liquid assets to deposits and short term funding. It represents the liquidity of a banking institution; Liquid assets to assets is the ratio of liquid assets to assets. It reports the amount of liquid assets available and therefore the liquidity position of a banking institution; Liquid assets to total deposits is similar to Maturity match and is computed by dividing a bank's liquid assets by its total deposits and borrowing; Size is the logarithm of total assets; Tangibility is the ratio of fixed assets over total assets; Activity diversification is the ratio of net loans over total earning assets; ROAA is the return on average assets ratio; CIR is the cost to income ratio; OVERTA is the overhead to assets ratio. We perform a series of t-tests of the null hypothesis that the means derived for our Islamic and conventional bank sample are equal (specifically, we use Satterthwaite tests because they allow subsample variances to be different). Wilc-test represents a Wilcoxon rank test which tests the null hypothesis that the two samples are derived from different distributions (where normality is not assumed). *,**, and $* * *$ represent significance at the $10 \%, 5 \%$, and $1 \%$ level, respectively. 
Table 3

The effect of higher capital and liquidity on bank efficiency: Islamic vs. conventional banks

\begin{tabular}{|c|c|c|c|c|c|c|c|c|c|}
\hline \multicolumn{10}{|c|}{ Panel A: The impact of capital ratios on bank efficiency } \\
\hline Model \# & (1) & (2) & (3) & (4) & (5) & (6) & (7) & $(8)$ & (9) \\
\hline Quantile & 0.25 & 0.50 & 0.75 & 0.25 & 0.50 & 0.75 & 0.25 & 0.50 & 0.75 \\
\hline Islamic & $11.79 * * *$ & $22.98 * * *$ & $27.31 * * *$ & $11.71 * * *$ & $23.86^{* * * *}$ & $30.16^{* * *}$ & $16.19^{* * *}$ & $31.40 * * *$ & $34.07 * * *$ \\
\hline & $(3.681)$ & $(5.705)$ & $(3.697)$ & $(3.354)$ & $(5.577)$ & $(5.548)$ & $(2.925)$ & $(4.366)$ & $(4.233)$ \\
\hline Tier1 capital $\left[\vartheta_{\mathrm{CAP}}\right]$ & $\begin{array}{l}0.057 \\
(0.100)\end{array}$ & $\begin{array}{l}0.314 * * \\
(0.128)\end{array}$ & $\begin{array}{l}0.422 * * * \\
(0.161)\end{array}$ & & & & & & \\
\hline Tier1 capital & 0.176 & -0.018 & -0.207 & & & & & & \\
\hline$\times$ Islamic $\left[\vartheta_{\text {inter }}^{*}\right]$ & $(0.128)$ & $(0.223)$ & $(0.158)$ & & & & & & \\
\hline Capital adequacy $\left[\vartheta_{\mathrm{CAP}}\right]$ & & & & $\begin{array}{l}0.076 \\
(0.093)\end{array}$ & $\begin{array}{l}0.343 * * \\
(0.139)\end{array}$ & $\begin{array}{l}0.513 * \\
(0.273)\end{array}$ & & & \\
\hline Capital adequacy & & & & 0.166 & -0.075 & -0.301 & & & \\
\hline$\times$ Islamic $\left[\vartheta_{\text {inter }}^{*}\right]$ & & & & $(0.122)$ & $(0.199)$ & $(0.257)$ & & & \\
\hline Shareholders' equity $\left[\vartheta_{\mathrm{CAP}}\right]$ & & & & & & & $\begin{array}{l}0.59 * * * \\
(0.095)\end{array}$ & $\begin{array}{l}0.86^{* * * *} \\
(0.076)\end{array}$ & $\begin{array}{l}1.164 * * * \\
(0.128)\end{array}$ \\
\hline $\begin{array}{l}\text { Shareholders' equity } \\
\times \text { Islamic }\left[\vartheta_{i n t e r}^{*}\right]\end{array}$ & & & & & & & $\begin{array}{l}-0.16 \\
(0.152)\end{array}$ & $\begin{array}{l}-0.481 * * * \\
(0.133)\end{array}$ & $\begin{array}{l}-0.668 * * * \\
(0.254)\end{array}$ \\
\hline Size & $\begin{array}{l}5.092 * * * \\
(0.668)\end{array}$ & $\begin{array}{l}5.374 * * * \\
(0.644)\end{array}$ & $\begin{array}{l}3.884 * * * \\
(0.732)\end{array}$ & $\begin{array}{l}4.367 * * * \\
(0.629)\end{array}$ & $\begin{array}{l}4.856^{* * *} \\
(0.557)\end{array}$ & $\begin{array}{l}3.526^{* * * *} \\
(0.589)\end{array}$ & $\begin{array}{l}4.654 * * * \\
(0.596)\end{array}$ & $\begin{array}{l}5.481 * * * \\
(0.532)\end{array}$ & $\begin{array}{l}4.254 * * * \\
(0.463)\end{array}$ \\
\hline Tangibility & $\begin{array}{l}-0.804 \\
(0.497)\end{array}$ & $\begin{array}{l}-1.478^{*} \\
(0.764)\end{array}$ & $\begin{array}{l}-1.327 * * * \\
(0.437)\end{array}$ & $\begin{array}{l}-0.498 \\
(0.443)\end{array}$ & $\begin{array}{l}-1.351 * * \\
(0.651)\end{array}$ & $\begin{array}{l}-1.43 * * \\
(0.591)\end{array}$ & $\begin{array}{l}-1.227 * * * \\
(0.395)\end{array}$ & $\begin{array}{l}-1.671 * * * \\
(0.590)\end{array}$ & $\begin{array}{l}-1.628 * * * \\
(0.493)\end{array}$ \\
\hline Activity diversification & $\begin{array}{l}-0.227 * * * \\
(0.056)\end{array}$ & $\begin{array}{l}-0.154 * * * \\
(0.053)\end{array}$ & $\begin{array}{l}-0.114^{* *} \\
(0.056)\end{array}$ & $\begin{array}{l}-0.161 * * * \\
(0.050)\end{array}$ & $\begin{array}{l}-0.096^{*} \\
(0.050)\end{array}$ & $\begin{array}{l}-0.062 \\
(0.054)\end{array}$ & $\begin{array}{l}-0.127 * * * \\
(0.031)\end{array}$ & $\begin{array}{l}-0.137 * * * \\
(0.035)\end{array}$ & $\begin{array}{l}-0.122 * * * \\
(0.038)\end{array}$ \\
\hline Cost to income & $\begin{array}{l}-0.104 * * * \\
(0.016)\end{array}$ & $\begin{array}{l}-0.075 * * * \\
(0.026)\end{array}$ & $\begin{array}{l}-0.070 \text { *** } \\
(0.025)\end{array}$ & $\begin{array}{l}-0.117 \text { *** } \\
(0.036)\end{array}$ & $\begin{array}{l}-0.092 * * \\
(0.043)\end{array}$ & $\begin{array}{l}-0.079 * * * \\
(0.027)\end{array}$ & $\begin{array}{l}-0.098 * * * \\
(0.020)\end{array}$ & $\begin{array}{l}-0.068^{* * *} \\
(0.021)\end{array}$ & $\begin{array}{l}-0.057 * * * \\
(0.017)\end{array}$ \\
\hline Legal & $\begin{array}{l}7.496 \\
(9.252)\end{array}$ & $\begin{array}{l}4.753 \\
(7.784)\end{array}$ & $\begin{array}{l}6.159 \\
(10.73)\end{array}$ & $\begin{array}{l}0.527 \\
(8.680)\end{array}$ & $\begin{array}{l}-1.281 \\
(8.246)\end{array}$ & $\begin{array}{l}9.003 \\
(11.91)\end{array}$ & $\begin{array}{l}-2.878 \\
(7.620)\end{array}$ & $\begin{array}{l}-2.841 \\
(5.779)\end{array}$ & $\begin{array}{l}0.226 \\
(11.60)\end{array}$ \\
\hline GDP per capita & $\begin{array}{l}7.937 \\
(5.019)\end{array}$ & $\begin{array}{l}6.904 * \\
(4.102)\end{array}$ & $\begin{array}{l}7.999 \\
(5.917)\end{array}$ & $\begin{array}{l}3.186 \\
(4.380)\end{array}$ & $\begin{array}{l}2.407 \\
(4.413)\end{array}$ & $\begin{array}{l}9.113^{*} \\
(5.438)\end{array}$ & $\begin{array}{l}-0.707 \\
(2.995)\end{array}$ & $\begin{array}{l}-0.948 \\
(3.080)\end{array}$ & $\begin{array}{l}1.941 \\
(3.925)\end{array}$ \\
\hline GDP growth & $\begin{array}{l}0.616^{* * *} \\
(0.187)\end{array}$ & $\begin{array}{l}0.786^{* * *} \\
(0.178)\end{array}$ & $\begin{array}{l}0.599 * * * \\
(0.223)\end{array}$ & $\begin{array}{l}0.562 * * * \\
(0.160)\end{array}$ & $\begin{array}{l}0.776^{* * * *} \\
(0.156)\end{array}$ & $\begin{array}{l}0.587 * * \\
(0.246)\end{array}$ & $\begin{array}{l}0.448 * * * \\
(0.130)\end{array}$ & $\begin{array}{l}0.627 \text { *** } \\
(0.141)\end{array}$ & $\begin{array}{l}0.545^{* * * *} \\
(0.183)\end{array}$ \\
\hline Inflation & $\begin{array}{l}0.075 \\
(0.142)\end{array}$ & $\begin{array}{l}-0.028 \\
(0.191)\end{array}$ & $\begin{array}{l}-0.122 \\
(0.191)\end{array}$ & $\begin{array}{l}0.27^{*} \\
(0.140)\end{array}$ & $\begin{array}{l}0.108 \\
(0.133)\end{array}$ & $\begin{array}{l}0.004 \\
(0.163)\end{array}$ & $\begin{array}{l}0.172 \\
(0.145)\end{array}$ & $\begin{array}{l}0.076 \\
(0.115)\end{array}$ & $\begin{array}{l}0.045 \\
(0.161)\end{array}$ \\
\hline Intercept & $\begin{array}{l}-76.55^{*} \\
(42.11)\end{array}$ & $\begin{array}{l}-70.15^{*} \\
(36.14)\end{array}$ & $\begin{array}{l}-54.62 \\
(51.10)\end{array}$ & $\begin{array}{l}-33.86 \\
(37.55)\end{array}$ & $\begin{array}{l}-34.10 \\
(38.22)\end{array}$ & $\begin{array}{l}-68.15 \\
(46.41)\end{array}$ & $\begin{array}{l}-8.794 \\
(26.15)\end{array}$ & $\begin{array}{l}-14.57 \\
(25.45)\end{array}$ & $\begin{array}{l}-14.42 \\
(32.02)\end{array}$ \\
\hline Obs. & 2071 & 2071 & 2071 & 2550 & 2550 & 2550 & 3583 & 3583 & 3583 \\
\hline CFE \& YFE & Yes & Yes & Yes & Yes & Yes & Yes & Yes & Yes & Yes \\
\hline $\mathrm{R} 2$ & 0.479 & 0.507 & 0.488 & 0.434 & 0.47 & 0.453 & 0.408 & 0.435 & 0.416 \\
\hline$\vartheta_{\text {CAP }}:$ Wald test (F-stat.): Q $[0.2$ & ]$=Q[0.75]$ & & N/A & & & $18.52 * * *$ & & & $28.59 * * *$ \\
\hline The impact of capital on Islami & banks' effic & ncy $\left[\vartheta_{\mathrm{CAP}}+\right.$ & $\left.\theta_{\text {inter }}^{*}\right]$ comp & to conventi & l banks' e & iency $\left[\vartheta_{\mathrm{CAP}}\right]$ & & & \\
\hline & $\begin{array}{l}0.233^{* *} \\
(0.081)\end{array}$ & $\begin{array}{l}0.295 \\
(0.194)\end{array}$ & $\begin{array}{l}0.215^{* * *} \\
(0.051)\end{array}$ & $\begin{array}{l}0.242 * * * \\
(0.067)\end{array}$ & $\begin{array}{l}0.267^{*} \\
(0.155)\end{array}$ & $\begin{array}{l}0.212 * * * \\
(0.055)\end{array}$ & $\begin{array}{l}0.43 * * * \\
(0.126)\end{array}$ & $\begin{array}{l}0.379 * * * \\
(0.110)\end{array}$ & $\begin{array}{l}0.495 * * \\
(0.229)\end{array}$ \\
\hline$\vartheta_{\mathrm{CAP}}+\vartheta_{\text {inter }}^{*}:$ Wald test (F-sta & .): $\mathrm{Q}[0.25]=$ & {$[0.75]$} & N/A & & & 0.05 & & & 0.19 \\
\hline Panel B: The impact of liquidi & y ratios on $b$ & $\mathrm{k}$ efficiency & & & & & & & \\
\hline Model \# & (1) & (2) & (3) & (4) & (5) & (6) & (7) & (8) & (9) \\
\hline Quantile & 0.25 & 0.50 & 0.75 & 0.25 & 0.50 & 0.75 & 0.25 & 0.50 & 0.75 \\
\hline Islamic & $\begin{array}{l}16.8^{* * * *} \\
(3.047)\end{array}$ & $\begin{array}{l}28.11^{* * * *} \\
(4.225)\end{array}$ & $\begin{array}{l}27.79 * * * \\
(3.680)\end{array}$ & $\begin{array}{l}15.13 * * * \\
(4.919)\end{array}$ & $\begin{array}{l}26.01 * * * \\
(6.935)\end{array}$ & $\begin{array}{l}24.43^{* * *} \\
(4.185)\end{array}$ & $\begin{array}{l}22.33^{* * * *} \\
(5.008)\end{array}$ & $\begin{array}{l}33.11 * * * * \\
(4.715)\end{array}$ & $\begin{array}{l}30.21 * * * \\
(5.632)\end{array}$ \\
\hline $\begin{array}{l}\text { Liquid assets to deposits } \\
{\left[\vartheta_{\text {LIQ }}\right]}\end{array}$ & $\begin{array}{l}0.114 * * * \\
(0.020)\end{array}$ & $\begin{array}{l}0.14 * * * \\
(0.013)\end{array}$ & $\begin{array}{l}0.145^{* * * *} \\
(0.042)\end{array}$ & & & & & & \\
\hline $\begin{array}{l}\text { Liquid assets to deposits } \times \\
\text { Islamic }\left[\vartheta_{\text {inter }}^{*}\right]\end{array}$ & $\begin{array}{l}-0.056^{*} \\
(0.031)\end{array}$ & $\begin{array}{l}-0.085 * * * \\
(0.027)\end{array}$ & $\begin{array}{l}-0.091 * * \\
(0.045)\end{array}$ & & & & & & \\
\hline Liquid assets to assets $\left[\vartheta_{\mathrm{LIQ}}\right]$ & & & & $\begin{array}{l}0.016 \\
(0.037)\end{array}$ & $\begin{array}{l}0.031 \\
(0.047)\end{array}$ & $\begin{array}{l}0.079 \\
(0.068)\end{array}$ & & & \\
\hline Liquid assets to assets $x$ & & & & 0.027 & 0.001 & -0.053 & & & \\
\hline Islamic $\left[\vartheta_{\text {inter }}^{*}\right]$ & & & & $(0.130)$ & $(0.196)$ & $(0.096)$ & & & \\
\hline $\begin{array}{l}\text { Liquid assets to total deposits } \\
{\left[\vartheta_{\text {LIO }}\right]}\end{array}$ & & & & & & & $\begin{array}{l}0.046^{*} \\
(0.025)\end{array}$ & $\begin{array}{l}0.105^{* *} \\
(0.048)\end{array}$ & $\begin{array}{l}0.129 * * * \\
(0.048)\end{array}$ \\
\hline $\begin{array}{l}\text { Liquid assets to total deposits } \\
\times \text { Islamic }\left[\vartheta_{\text {inter }}^{*}\right]\end{array}$ & & & & & & & $\begin{array}{l}-0.012 \\
(0.074)\end{array}$ & $\begin{array}{l}-0.065 \\
(0.071)\end{array}$ & $\begin{array}{l}-0.121 * * \\
(0.061)\end{array}$ \\
\hline Size & $\begin{array}{l}3.882 * * * \\
(0.476)\end{array}$ & $\begin{array}{l}4.1 * * * \\
(0.517)\end{array}$ & $\begin{array}{l}2.580 * * * \\
(0.542)\end{array}$ & $\begin{array}{l}3.66 * * * \\
(0.500)\end{array}$ & $\begin{array}{l}3.429 * * * \\
(0.679)\end{array}$ & $\begin{array}{l}1.504 * * \\
(0.675)\end{array}$ & $\begin{array}{l}4.273 * * * \\
(0.645)\end{array}$ & $\begin{array}{l}4.571 * * * \\
(0.614)\end{array}$ & $\begin{array}{l}3.074 * * * \\
(0.700)\end{array}$ \\
\hline Tangibility & $\begin{array}{l}-0.864 * * \\
(0.378)\end{array}$ & $\begin{array}{l}-0.826 \\
(0.539)\end{array}$ & $\begin{array}{l}-0.871 \\
(0.660)\end{array}$ & $\begin{array}{l}-0.805 \\
(0.499)\end{array}$ & $\begin{array}{l}-0.981 \\
(0.622)\end{array}$ & $\begin{array}{l}-0.986 \\
(0.630)\end{array}$ & $\begin{array}{l}-0.297 \\
(0.608)\end{array}$ & $\begin{array}{l}-0.877 \\
(0.669)\end{array}$ & $\begin{array}{l}-1.191 \\
(1.289)\end{array}$ \\
\hline Cost to income & $\begin{array}{l}-0.102 * * * \\
(0.021)\end{array}$ & $\begin{array}{l}-0.097 * * * \\
(0.028)\end{array}$ & $\begin{array}{l}-0.084 * * * \\
(0.030)\end{array}$ & $\begin{array}{l}-0.103 * * * \\
(0.022)\end{array}$ & $\begin{array}{l}-0.1 * * * \\
(0.030)\end{array}$ & $\begin{array}{l}-0.079 * * * \\
(0.026)\end{array}$ & $\begin{array}{l}-0.153 * * * \\
(0.033)\end{array}$ & $\begin{array}{l}-0.15 * * * \\
(0.040)\end{array}$ & $\begin{array}{l}-0.129 * * * \\
(0.024)\end{array}$ \\
\hline Legal & $\begin{array}{l}-2.689 \\
(6.693)\end{array}$ & $\begin{array}{l}3.457 \\
(6.448)\end{array}$ & $\begin{array}{l}12.26 \\
(11.85)\end{array}$ & $\begin{array}{l}-6.348 \\
(7.960)\end{array}$ & $\begin{array}{l}0.437 \\
(7.397)\end{array}$ & $\begin{array}{l}10.08 \\
(11.91)\end{array}$ & $\begin{array}{l}-6.733 \\
(7.891)\end{array}$ & $\begin{array}{l}-4.286 \\
(7.956)\end{array}$ & $\begin{array}{l}4.918 \\
(10.39)\end{array}$ \\
\hline GDP per capita & $\begin{array}{l}1.648 \\
(2.862)\end{array}$ & $\begin{array}{l}3.649 \\
(3.416)\end{array}$ & $\begin{array}{l}8.411 * * \\
(4.002)\end{array}$ & $\begin{array}{l}-0.995 \\
(3.460)\end{array}$ & $\begin{array}{l}0.659 \\
(3.800)\end{array}$ & $\begin{array}{l}6.674 * \\
(3.655)\end{array}$ & $\begin{array}{l}-3.666 \\
(3.741)\end{array}$ & $\begin{array}{l}-3.318 \\
(4.098)\end{array}$ & $\begin{array}{l}4.478 \\
(4.797)\end{array}$ \\
\hline GDP growth & $\begin{array}{l}0.432 * * * \\
(0.129)\end{array}$ & $\begin{array}{l}0.55 * * * \\
(0.151)\end{array}$ & $\begin{array}{l}0.455^{* * *} * \\
(0.168)\end{array}$ & $\begin{array}{l}0.55 * * * \\
(0.141)\end{array}$ & $\begin{array}{l}0.675^{* * *} \\
(0.156)\end{array}$ & $\begin{array}{l}0.527 * * * \\
(0.188)\end{array}$ & $\begin{array}{l}0.721 * * * \\
(0.179)\end{array}$ & $\begin{array}{l}0.776^{* * * *} \\
(0.197)\end{array}$ & $\begin{array}{l}0.861 * * * \\
(0.214)\end{array}$ \\
\hline Inflation & $\begin{array}{l}0.038 \\
(0.131)\end{array}$ & $\begin{array}{l}0.098 \\
(0.115)\end{array}$ & $\begin{array}{l}-0.169 \\
(0.137)\end{array}$ & $\begin{array}{l}0.096 \\
(0.142)\end{array}$ & $\begin{array}{l}0.155 \\
(0.127)\end{array}$ & $\begin{array}{l}-0.147 \\
(0.126)\end{array}$ & $\begin{array}{l}0.142 \\
(0.132)\end{array}$ & $\begin{array}{l}0.179 \\
(0.188)\end{array}$ & $\begin{array}{l}-0.011 \\
(0.215)\end{array}$ \\
\hline
\end{tabular}




\begin{tabular}{|c|c|c|c|c|c|c|c|c|c|}
\hline Intercept & $\begin{array}{l}-17.23 \\
(26.08)\end{array}$ & $\begin{array}{l}-37.11 \\
(27.41)\end{array}$ & $\begin{array}{l}-47.6 \\
(35.63)\end{array}$ & $\begin{array}{l}9.814 \\
(30.55)\end{array}$ & $\begin{array}{l}-0.757 \\
(33.43)\end{array}$ & $\begin{array}{l}-15.04 \\
(33.06)\end{array}$ & $\begin{array}{l}17.73 \\
(34.49)\end{array}$ & $\begin{array}{l}17.60 \\
(35.17)\end{array}$ & $\begin{array}{l}-1.022 \\
(38.76)\end{array}$ \\
\hline Obs. & 3576 & 3576 & 3576 & 3577 & 3577 & 3577 & 2560 & 2560 & 2560 \\
\hline CFE \& YFE & Yes & Yes & Yes & Yes & Yes & Yes & Yes & Yes & Yes \\
\hline R2 & 0.384 & 0.406 & 0.394 & 0.331 & 0.358 & 0.34 & 0.389 & 0.408 & 0.393 \\
\hline \multicolumn{10}{|c|}{ The impact of liquidity on Islamic banks' efficiency $\left[\vartheta_{\mathrm{LIQ}}+\vartheta_{\text {inter }}^{*}\right]$ compared to conventional banks' efficiency [ $\left.\vartheta_{\mathrm{LIQ}}\right]$} \\
\hline & $\begin{array}{l}0.057 * * \\
(0.024)\end{array}$ & $\begin{array}{l}0.056^{* * *} \\
(0.042)\end{array}$ & $\begin{array}{l}0.054 * * * \\
(0.009)\end{array}$ & $\begin{array}{l}0.043 \\
(0.134)\end{array}$ & $\begin{array}{l}0.031 \\
(0.020)\end{array}$ & $\begin{array}{l}0.025 \\
(0.073)\end{array}$ & $\begin{array}{l}0.035 \\
(0.073)\end{array}$ & $\begin{array}{l}0.04 \\
(0.051)\end{array}$ & $\begin{array}{l}0.008 \\
(0.037)\end{array}$ \\
\hline \multicolumn{3}{|c|}{$\vartheta_{\text {LIO }}+\vartheta_{\text {inter }}^{*}:$ Wald test (F-stat.): Q[0.25] = Q $[0.75]$} & 0.03 & & & 0.03 & & & N/A \\
\hline
\end{tabular}

Note: This table documents the capital and liquidity determinants of efficiency by comparing Islamic and conventional banks using conditional quantile regressions for the period from 2005 to 2012. The dependent variable is pure technical efficiency (loan loss provision). It is computed by comparing banks to their own efficiency frontier. BC and CC represent bank level and country level characteristics. CFE and YFE represent country and year fixed effect dummy variables. In addition, we include interaction terms between Islamic and the capital and liquidity ratios. We present the $25^{\text {th }}, 50^{\text {th }}$, and $75^{\text {th }}$ quantile of our dependent variable. Standard errors are clustered at the bank level and are reported in parentheses below their coefficient estimates. *,**, and *** represent significance at the $10 \%, 5 \%$, and $1 \%$ level, respectively. 
Table 4

The effect of capital and liquidity on bank efficiency: Classification by bank size

\begin{tabular}{|c|c|c|c|c|c|c|c|c|c|c|c|c|c|}
\hline \multirow{2}{*}{\multicolumn{7}{|c|}{ Panel A: The impact of capital ratios on bank efficiency }} & \multicolumn{7}{|c|}{ Panel B: The impact of liquidity ratios on bank efficiency } \\
\hline & & \multicolumn{2}{|c|}{ Large banks } & \multicolumn{3}{|c|}{ Small banks } & \multicolumn{4}{|c|}{ Large banks } & \multicolumn{3}{|c|}{ Small banks } \\
\hline Model \# & (1) & (2) & (3) & (4) & (5) & (6) & Model \# & (7) & (8) & (9) & (10) & (11) & (12) \\
\hline Quantile & 0.25 & 0.50 & 0.75 & 0.25 & 0.50 & 0.75 & Quantile & 0.25 & 0.50 & 0.75 & 0.25 & 0.50 & 0.75 \\
\hline Islamic & $\begin{array}{l}16.61 * * * \\
(4.855)\end{array}$ & $\begin{array}{l}21.83 * * * \\
(8.069)\end{array}$ & $\begin{array}{l}29.96^{* * *} \\
(10.40)\end{array}$ & $\begin{array}{l}3.746 \\
(4.360)\end{array}$ & $\begin{array}{l}12.34 * \\
(6.394)\end{array}$ & $\begin{array}{l}26.19^{* * * *} \\
(10.13)\end{array}$ & Islamic & $\begin{array}{l}21.21 * * * \\
(3.378)\end{array}$ & $\begin{array}{l}29.07 * * * * \\
(2.644)\end{array}$ & $\begin{array}{l}26.91 * * * \\
(4.040)\end{array}$ & $\begin{array}{l}8.978 * * * \\
(2.781)\end{array}$ & $\begin{array}{l}22.42 * * * * \\
(5.746)\end{array}$ & $\begin{array}{l}33.75 * * * \\
(5.402)\end{array}$ \\
\hline Tier1 capital $\left[\vartheta_{\mathrm{CAP}}\right]$ & $\begin{array}{l}-0.041 \\
(0.226)\end{array}$ & $\begin{array}{l}0.059 \\
(0.217)\end{array}$ & $\begin{array}{l}0.463 * * \\
(0.229)\end{array}$ & $\begin{array}{l}0.002 \\
(0.078)\end{array}$ & $\begin{array}{l}0.068 \\
(0.130)\end{array}$ & $\begin{array}{l}0.315^{*} \\
(0.191)\end{array}$ & $\begin{array}{l}\text { Liquid assets to deposits } \\
{\left[\vartheta_{\text {LIQ }}\right]}\end{array}$ & $\begin{array}{l}0.069 * * * \\
(0.017)\end{array}$ & $\begin{array}{l}0.089 * * * \\
(0.022)\end{array}$ & $\begin{array}{l}0.077 * * * \\
(0.021)\end{array}$ & $\begin{array}{l}0.098 * * * \\
(0.019)\end{array}$ & $\begin{array}{l}0.125^{* * * *} \\
(0.014)\end{array}$ & $\begin{array}{l}0.143^{* * *} \\
(0.029)\end{array}$ \\
\hline $\begin{array}{l}\text { Tier1 capital } \times \text { Islamic } \\
{\left[\vartheta_{\text {inter }}^{*}\right]}\end{array}$ & $\begin{array}{l}0.315 \\
(0.218)\end{array}$ & $\begin{array}{l}0.227 \\
(0.505)\end{array}$ & $\begin{array}{l}-0.241 \\
(0.641)\end{array}$ & $\begin{array}{l}0.189 * * \\
(0.093)\end{array}$ & $\begin{array}{l}0.203 \\
(0.136)\end{array}$ & $\begin{array}{l}-0.206 \\
(0.202)\end{array}$ & $\begin{array}{l}\text { Liquid assets to deposits } \times \\
\text { Islamic }\left[\vartheta_{\text {inter }}^{*}\right]\end{array}$ & $\begin{array}{l}-0.016 \\
(0.023)\end{array}$ & $\begin{array}{l}-0.053^{*} \\
(0.030)\end{array}$ & $\begin{array}{l}-0.042 \\
(0.085)\end{array}$ & $\begin{array}{l}-0.039 * \\
(0.021)\end{array}$ & $\begin{array}{l}-0.086 * * * \\
(0.017)\end{array}$ & $\begin{array}{l}-0.125 * * * \\
(0.034)\end{array}$ \\
\hline Intercept & $\begin{array}{l}-137.7^{* * * *} \\
(51.08)\end{array}$ & $\begin{array}{l}-104.3 * * \\
(45.67)\end{array}$ & $\begin{array}{l}-110.8^{* *} \\
(55.51)\end{array}$ & $\begin{array}{l}161.7^{*} \\
(88.62)\end{array}$ & $\begin{array}{l}66.62 \\
(136.8)\end{array}$ & $\begin{array}{l}43.1 \\
(236.3)\end{array}$ & Intercept & $\begin{array}{l}-106.9 * * * \\
(35.68)\end{array}$ & $\begin{array}{l}-65.78^{* *} \\
(28.94)\end{array}$ & $\begin{array}{l}-71.92 \\
(48.36)\end{array}$ & $\begin{array}{l}43.33^{*} \\
(25.91)\end{array}$ & $\begin{array}{l}45.50 \\
(29.41)\end{array}$ & $\begin{array}{l}140.2 * * * \\
(49.29)\end{array}$ \\
\hline Obs. & 1404 & 1404 & 1404 & 667 & 667 & 667 & Obs. & 2006 & 2006 & 2006 & 1570 & 1570 & 1570 \\
\hline $\mathrm{BC} \& \mathrm{CC}$ & Yes & Yes & Yes & Yes & Yes & Yes & $\mathrm{BC} \& \mathrm{CC}$ & Yes & Yes & Yes & Yes & Yes & Yes \\
\hline CFE \& YFE & Yes & Yes & Yes & Yes & Yes & Yes & CFE \& YFE & Yes & Yes & Yes & Yes & Yes & Yes \\
\hline R2 & 0.567 & 0.589 & 0.572 & 0.367 & 0.403 & 0.376 & R2 & 0.486 & 0.515 & 0.494 & 0.339 & 0.374 & 0.349 \\
\hline \multicolumn{7}{|c|}{$\vartheta_{\mathrm{CAP}}:$ Wald test (F-stat.): Q[0.25] = Q $[0.75]$} & \multicolumn{4}{|c|}{$\vartheta_{\text {LIQ }}:$ Wald test (F-stat.): Q $[0.25]=\mathrm{Q}[0.75]$} & & & $2.74 *$ \\
\hline \multicolumn{7}{|c|}{$\begin{array}{l}\text { The impact of capital on Islamic banks' efficiency }\left[\vartheta_{\mathrm{CAP}}+\vartheta_{\text {inter }}^{*}\right] \text { compared to conventional banks' efficiency } \\
{\left[\vartheta_{\mathrm{CAP}}\right]}\end{array}$} & \multicolumn{7}{|c|}{$\begin{array}{l}\text { The impact of liquidity on Islamic banks' efficiency }\left[\vartheta_{\text {LIQ }}+\vartheta_{\text {inter }}^{*}\right] \text { compared to conventional banks' efficiency } \\
{\left[\vartheta_{\text {LIQ }}\right]}\end{array}$} \\
\hline & $\begin{array}{l}0.274 * * \\
(0.133)\end{array}$ & $\begin{array}{l}0.286 \\
(0.477)\end{array}$ & $\begin{array}{l}0.222 \\
(0.611)\end{array}$ & $\begin{array}{l}0.191 * * \\
(0.078)\end{array}$ & $\begin{array}{l}0.271 * * * \\
(0.076)\end{array}$ & $\begin{array}{l}0.109 \\
(0.089)\end{array}$ & & $\begin{array}{l}0.053 * * * \\
(0.013)\end{array}$ & $\begin{array}{l}0.036^{*} \\
(0.019)\end{array}$ & $\begin{array}{l}0.035 \\
(0.086)\end{array}$ & $\begin{array}{l}0.059 * * * \\
(0.008)\end{array}$ & $\begin{array}{l}0.039 * * * \\
(0.010)\end{array}$ & $\begin{array}{l}0.017 \\
(0.015)\end{array}$ \\
\hline \multicolumn{3}{|c|}{$\vartheta_{\mathrm{CAP}}+\vartheta_{\text {inter }}^{*}:$ Wald test (F-stat.): Q[0.25] $=\mathrm{Q}[0.75]$} & N/A & & & N/A & \multicolumn{3}{|c|}{$\vartheta_{\text {LIQ }}+\vartheta_{\text {inter }}^{*}:$ Wald test (F-stat.): Q $[0.25]=\mathrm{Q}[0.75]$} & 0.12 & & & $5.03 * *$ \\
\hline$\frac{\vartheta_{\text {CAP }}+\vartheta_{\text {inter }}^{*}: \text { Wald test }}{\text { Islamic }}$ & $\begin{array}{l}14.36^{* * * *} \\
(4.454)\end{array}$ & $\begin{array}{l}24.00 * * * \\
(7.588)\end{array}$ & $\begin{array}{l}25.76^{* * * *} \\
(5.161)\end{array}$ & $\begin{array}{l}3.709 \\
(3.473)\end{array}$ & $\begin{array}{l}13.62 * * \\
(6.826)\end{array}$ & $\begin{array}{l}28.93 * * * \\
(9.254)\end{array}$ & \multirow{4}{*}{$\begin{array}{l}\text { Islamic } \\
\text { Liquid assets to assets } \\
{\left[\vartheta_{\text {LiQ }}\right]} \\
\text { Liquid assets to assets } \times \\
\text { Islamic }\left[\vartheta_{\text {inter }}^{*}\right] \\
\text { Intercept }\end{array}$} & $\begin{array}{l}26.0 * * * \\
(7.408)\end{array}$ & $\begin{array}{l}22.86 * * * \\
(5.001)\end{array}$ & $\begin{array}{l}23.38 * * * \\
(4.139)\end{array}$ & $\begin{array}{l}3.744 \\
(3.935)\end{array}$ & $\begin{array}{l}16.07 \\
(10.80)\end{array}$ & $\begin{array}{l}28.72 * * * \\
(7.899)\end{array}$ \\
\hline $\begin{array}{l}\text { Capital adequacy } \\
{\left[\vartheta_{\text {CAP }}\right]}\end{array}$ & $\begin{array}{l}-0.162 \\
(0.137)\end{array}$ & $\begin{array}{l}0.07 \\
(0.164)\end{array}$ & $\begin{array}{l}0.327 * \\
(0.198)\end{array}$ & $\begin{array}{l}0.075 \\
(0.068)\end{array}$ & $\begin{array}{l}0.222 * * \\
(0.097)\end{array}$ & $\begin{array}{l}0.438^{* * *} \\
(0.148)\end{array}$ & & $\begin{array}{l}-0.034 \\
(0.085)\end{array}$ & $\begin{array}{l}-0.008 \\
(0.058)\end{array}$ & $\begin{array}{l}-0.002 \\
(0.068)\end{array}$ & $\begin{array}{l}0.054 \\
(0.315)\end{array}$ & $\begin{array}{l}0.097^{*} \\
(0.054)\end{array}$ & $\begin{array}{l}0.13^{*} \\
(0.074)\end{array}$ \\
\hline $\begin{array}{l}\text { Capital adequacy } \\
\times \text { Islamic }\left[\vartheta_{\text {inter }}^{*}\right]\end{array}$ & $\begin{array}{l}0.444 * * \\
(0.173)\end{array}$ & $\begin{array}{l}0.173 \\
(0.399)\end{array}$ & $\begin{array}{l}0.154 \\
(0.210)\end{array}$ & $\begin{array}{l}0.187 * * \\
(0.081)\end{array}$ & $\begin{array}{l}0.079 \\
(0.111)\end{array}$ & $\begin{array}{l}-0.29^{*} \\
(0.152)\end{array}$ & & $\begin{array}{l}-0.186 \\
(0.375)\end{array}$ & $\begin{array}{l}0.242 \\
(0.205)\end{array}$ & $\begin{array}{l}0.099 \\
(0.109)\end{array}$ & $\begin{array}{l}0.114 \\
(0.107)\end{array}$ & $\begin{array}{l}-0.059 \\
(0.260)\end{array}$ & $\begin{array}{l}-0.071 \\
(0.145)\end{array}$ \\
\hline Intercept & $\begin{array}{l}-146.5^{* * * *} \\
(53.80)\end{array}$ & $\begin{array}{l}-88.51 * * \\
(39.00)\end{array}$ & $\begin{array}{l}-128.6^{* * * *} \\
(44.74)\end{array}$ & $\begin{array}{l}135.1^{*} \\
(70.59)\end{array}$ & $\begin{array}{l}170.2^{* *} \\
(80.50)\end{array}$ & $\begin{array}{l}120.1 \\
(91.19)\end{array}$ & & $\begin{array}{l}-86.35 * * \\
(39.89)\end{array}$ & $\begin{array}{l}-71.58^{* *} \\
(33.75)\end{array}$ & $\begin{array}{l}-76.61 * \\
(45.57)\end{array}$ & $\begin{array}{l}116.5^{* * * *} \\
(41.58)\end{array}$ & $\begin{array}{l}148.1 * * \\
(59.61)\end{array}$ & $\begin{array}{l}297.4 * * * \\
(94.14)\end{array}$ \\
\hline Obs. & 1599 & 1599 & 1599 & 951 & 951 & 951 & Obs. & 2006 & 2006 & 2006 & 1571 & 1571 & 1571 \\
\hline $\mathrm{BC} \& \mathrm{CC}$ & Yes & Yes & Yes & Yes & Yes & Yes & $\mathrm{BC} \& \mathrm{CC}$ & Yes & Yes & Yes & Yes & Yes & Yes \\
\hline CFE \& YFE & Yes & Yes & Yes & Yes & Yes & Yes & CFE \& YFE & Yes & Yes & Yes & Yes & Yes & Yes \\
\hline R2 & 0.539 & 0.566 & 0.548 & 0.32 & 0.369 & 0.34 & R2 & 0.474 & 0.504 & 0.485 & 0.275 & 0.318 & 0.302 \\
\hline \multicolumn{3}{|c|}{ F-stat.): Q $[0.25]=Q[0.75]$} & $6.65^{* *}$ & & & $13.61 * * *$ & $\vartheta_{\mathrm{LIQ}}:$ Wald test (F-stat.): $\mathrm{Q}[0$ & $25]=\mathrm{Q}[0.7$ & & 0.34 & & & 0.02 \\
\hline \multicolumn{7}{|c|}{$\begin{array}{l}\text { The impact of capital on Islamic banks' efficiency }\left[\vartheta_{\text {CAP }}+\vartheta_{\text {inter }}^{*}\right] \text { compared to conventional banks' efficiency } \\
{\left[\vartheta_{\text {CAP }}\right]}\end{array}$} & \multicolumn{7}{|c|}{$\begin{array}{l}\text { The impact of liquidity on Islamic banks' efficiency }\left[\vartheta_{\text {LIQ }}+\vartheta_{\text {inter }}^{*}\right] \text { compared to conventional banks' efficiency } \\
{\left[\vartheta_{\text {LIQ }}\right]}\end{array}$} \\
\hline & $\begin{array}{l}0.282^{* *} \\
(0.121)\end{array}$ & $\begin{array}{l}0.244 \\
(0.381)\end{array}$ & $\begin{array}{l}0.173 \\
(0.153)\end{array}$ & $\begin{array}{l}0.263 * * * \\
(0.070)\end{array}$ & $\begin{array}{l}0.301 * * * \\
(0.074)\end{array}$ & $\begin{array}{l}0.148^{*} \\
(0.083)\end{array}$ & & $\begin{array}{l}-0.219 \\
(0.366)\end{array}$ & $\begin{array}{l}0.234 \\
(0.197)\end{array}$ & $\begin{array}{l}0.097 \\
(0.083)\end{array}$ & $\begin{array}{l}0.168 \\
(0.104)\end{array}$ & $\begin{array}{l}0.038 \\
(0.206)\end{array}$ & $\begin{array}{l}-0.059 \\
(0.113)\end{array}$ \\
\hline \multicolumn{3}{|c|}{$\vartheta_{\mathrm{CAP}}+\vartheta_{\text {inter }}^{*}:$ Wald test (F-stat.): $\mathrm{Q}[0.25]=\mathrm{Q}[0.75]$} & 0.07 & & & 0.78 & \multicolumn{3}{|c|}{$\vartheta_{\text {LIQ }}+\vartheta_{\text {inter }}^{*}:$ Wald test (F-stat.): Q $[0.25]=\mathrm{Q}[0.75]$} & 1.76 & & & 1.61 \\
\hline Islamic & $\begin{array}{l}17.03^{* * * *} \\
(4.845)\end{array}$ & $\begin{array}{l}27.89 * * * \\
(5.043)\end{array}$ & $\begin{array}{l}30.54 * * * \\
(5.326)\end{array}$ & $\begin{array}{l}8.901 * * \\
(3.779)\end{array}$ & $\begin{array}{l}21.16^{* * * *} \\
(8.023)\end{array}$ & $\begin{array}{l}35.75^{* * * *} \\
(5.550)\end{array}$ & Islamic & $\begin{array}{l}26.78^{* *} \\
(11.58)\end{array}$ & $\begin{array}{l}28.3^{* * * *} \\
(3.451)\end{array}$ & $\begin{array}{l}27.82 * * * \\
(3.939)\end{array}$ & $\begin{array}{l}28.52^{*} \\
(14.97)\end{array}$ & $\begin{array}{l}39.87^{* * *} \\
(13.61)\end{array}$ & $\begin{array}{l}32.77 * * \\
(15.62)\end{array}$ \\
\hline $\begin{array}{l}\text { Shareholders' equity } \\
{\left[\vartheta_{\text {CAP }}\right]}\end{array}$ & $\begin{array}{l}0.037 \\
(0.215)\end{array}$ & $\begin{array}{l}0.313 \\
(0.220)\end{array}$ & $\begin{array}{l}0.554 \\
(0.351)\end{array}$ & $\begin{array}{l}0.51 * * * \\
(0.097)\end{array}$ & $\begin{array}{l}0.777 * * * \\
(0.120)\end{array}$ & $\begin{array}{l}1.03^{* * * *} \\
(0.175)\end{array}$ & $\begin{array}{l}\text { Liquid assets to total } \\
\text { deposits }\left[\vartheta_{\text {LIQ }}\right]\end{array}$ & $\begin{array}{l}-0.003 \\
(0.070)\end{array}$ & $\begin{array}{l}0.009 \\
(0.058)\end{array}$ & $\begin{array}{l}0.032 \\
(0.062)\end{array}$ & $\begin{array}{l}0.012 \\
(0.032)\end{array}$ & $\begin{array}{l}0.101^{*} \\
(0.059)\end{array}$ & $\begin{array}{l}0.14 * * \\
(0.060)\end{array}$ \\
\hline $\begin{array}{l}\text { Shareholders' equity } \times \\
\text { Islamic }\left[\vartheta_{\text {ing }}^{*}\right]\end{array}$ & $\begin{array}{l}0.407 * \\
(0.238)\end{array}$ & $\begin{array}{l}-0.019 \\
(0.340)\end{array}$ & $\begin{array}{l}-0.35 \\
(0.401)\end{array}$ & $\begin{array}{l}0.004 \\
(0.127)\end{array}$ & $\begin{array}{l}-0.318 \\
(0.258)\end{array}$ & $\begin{array}{l}-0.685^{* * *} \\
(0.207)\end{array}$ & $\begin{array}{l}\text { Liquid assets to total } \\
\text { deposits } \times \text { Islamic }\left[\vartheta_{i}^{*}\right]\end{array}$ & $\begin{array}{l}-0.015 \\
(0.609)\end{array}$ & $\begin{array}{l}0.064 \\
(0.073)\end{array}$ & $\begin{array}{l}-0.007 \\
(0.065)\end{array}$ & $\begin{array}{l}-0.103 \\
(0.140)\end{array}$ & $\begin{array}{l}-0.081 \\
(0.139)\end{array}$ & $\begin{array}{l}-0.068 \\
(0.114)\end{array}$ \\
\hline $\mathrm{BC} \& \mathrm{CC}$ & Yes & Yes & Yes & Yes & Yes & Yes & $\mathrm{BC} \& \mathrm{CC}$ & Yes & Yes & Yes & Yes & Yes & Yes \\
\hline
\end{tabular}




\begin{tabular}{|c|c|c|c|c|c|c|c|c|c|c|c|c|c|}
\hline CFE \& YFE & Yes & Yes & Yes & Yes & Yes & Yes & CFE \& YFE & Yes & Yes & Yes & Yes & Yes & Yes \\
\hline R2 & 0.5 & 0.537 & 0.518 & 0.37 & 0.398 & 0.383 & R2 & 0.508 & 0.523 & 0.501 & 0.331 & 0.358 & 0.348 \\
\hline$\vartheta_{\mathrm{CAP}}$ : Wald te & $\mathrm{Q}[0.25]=$ & 75] & $12.05 * * *$ & & & $17.79 * * *$ & $\vartheta_{\text {LIQ }}$ : Wald tes & $25]=\mathrm{Q}[$ & & N/A & & & $12.18 * * *$ \\
\hline \multicolumn{7}{|c|}{$\begin{array}{l}\text { The impact of capital on Islamic banks' efficiency }\left[\vartheta_{\text {CAP }}+\vartheta_{\text {inter }}^{*}\right] \text { compared to conventional banks' efficiency } \\
{\left[\vartheta_{\text {CAP }}\right]}\end{array}$} & \multicolumn{7}{|c|}{$\begin{array}{l}\text { The impact of liquidity on Islamic banks' efficiency }\left[\vartheta_{\mathrm{LIQ}}+\vartheta_{\text {inter }}^{*}\right] \text { compared to conventional banks' efficiency } \\
{\left[\vartheta_{\mathrm{LIO}}\right]}\end{array}$} \\
\hline & $\begin{array}{l}0.444 * * * \\
(0.127)\end{array}$ & $\begin{array}{l}0.294 \\
(0.271)\end{array}$ & $\begin{array}{l}0.204 \\
(0.185)\end{array}$ & $\begin{array}{l}0.515 * * * \\
(0.107)\end{array}$ & $\begin{array}{l}0.459^{* *} \\
(0.224)\end{array}$ & $\begin{array}{l}0.345^{* *} \\
(0.170)\end{array}$ & & $\begin{array}{l}-0.018 \\
(0.606)\end{array}$ & $\begin{array}{l}0.074 * \\
(0.041)\end{array}$ & $\begin{array}{l}0.025 \\
(0.022)\end{array}$ & $\begin{array}{l}-0.091 \\
(0.129)\end{array}$ & $\begin{array}{l}0.02 \\
(0.121)\end{array}$ & $\begin{array}{l}0.072 \\
(0.088)\end{array}$ \\
\hline \multicolumn{3}{|c|}{$\vartheta_{\text {CAP }}+\vartheta_{\text {inter }}^{*}:$ Wald test (F-stat.): $\mathrm{Q}[0.25]=\mathrm{Q}[0.75]$} & 0.1 & & & 1.18 & $\vartheta_{\mathrm{LIQ}}+\vartheta_{\text {inter }}^{*}:$ & t.): Q[0 & {$[0.75]$} & N/A & & & 0.55 \\
\hline
\end{tabular}

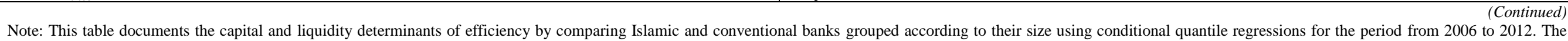

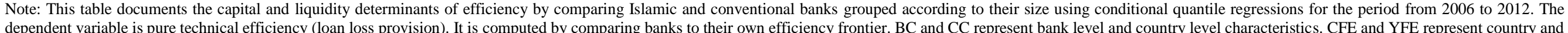

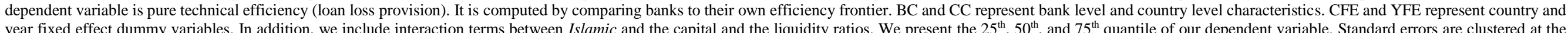
bank level and are reported in parentheses below their coefficient estimates. *, **, and *** represent significance at the $10 \%, 5 \%$, and $1 \%$ level, respectively. 
Table 5

The effect of capital and liquidity on bank efficiency: high liquidity vs. low liquidity and high capitalization vs. low capitalization banks

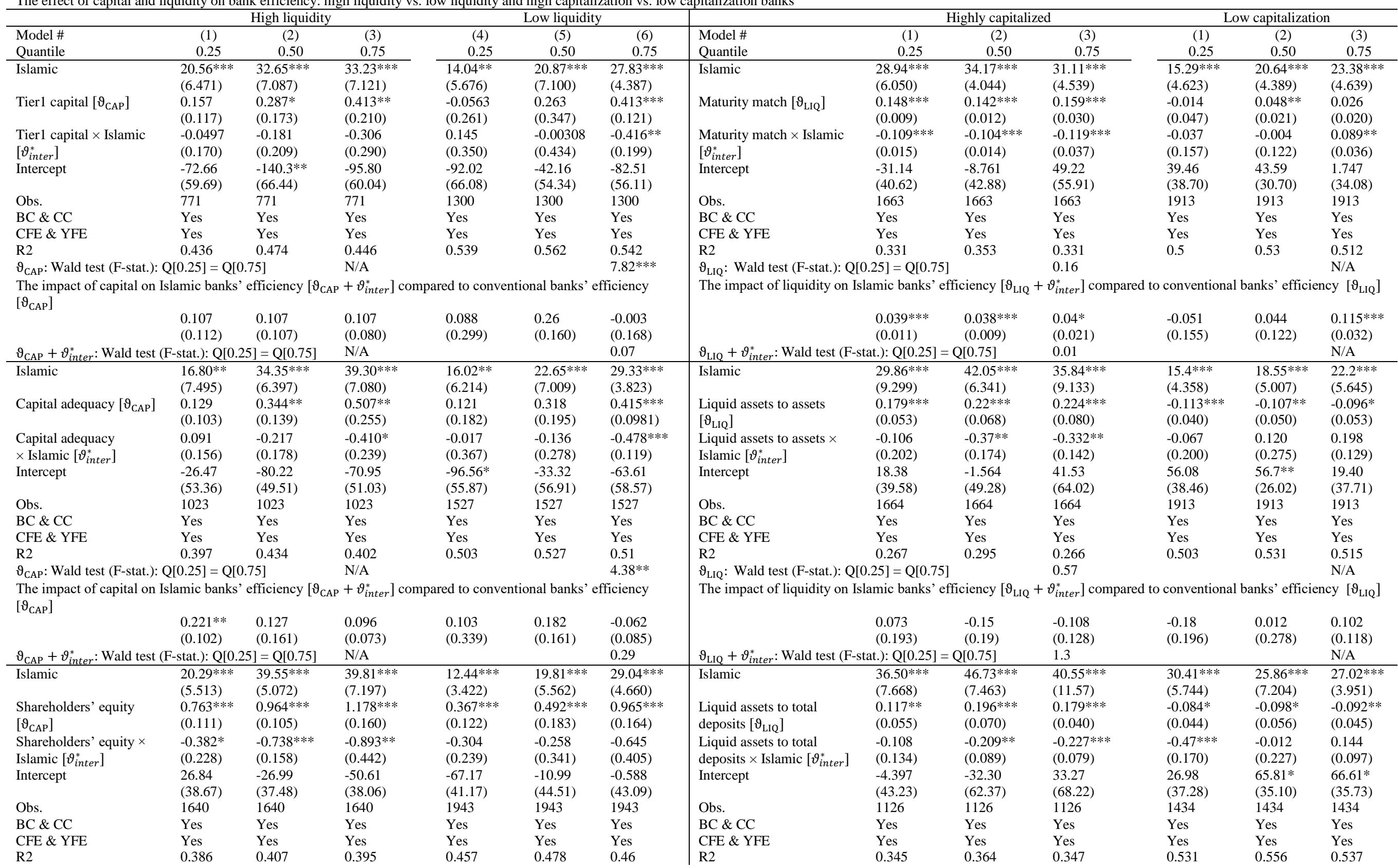




$\begin{array}{llllll}0.381^{* *} & 0.227^{*} & 0.285 & 0.063 & 0.234 & 0.32 \\ (0.191) & (0.121) & (0.419) & (0.182) & (0.158) & (0.241)\end{array}$

The impact of liquidity on Islamic banks' efficiency [

$\left.+\vartheta_{\text {inter }}^{*}\right]$

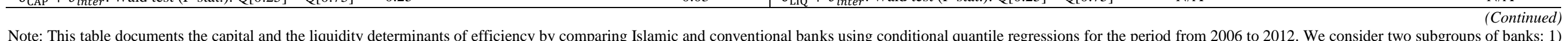

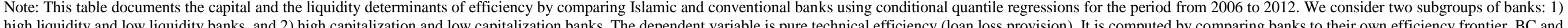

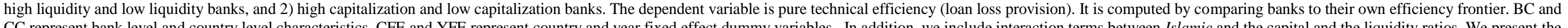

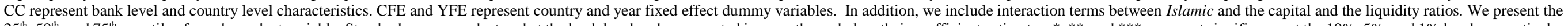

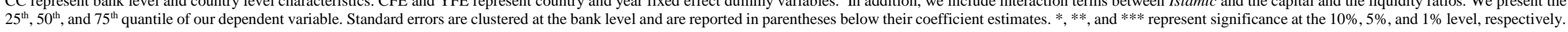


Table 6

The effect of capital and liquidity on bank efficiency during the subprime crisis

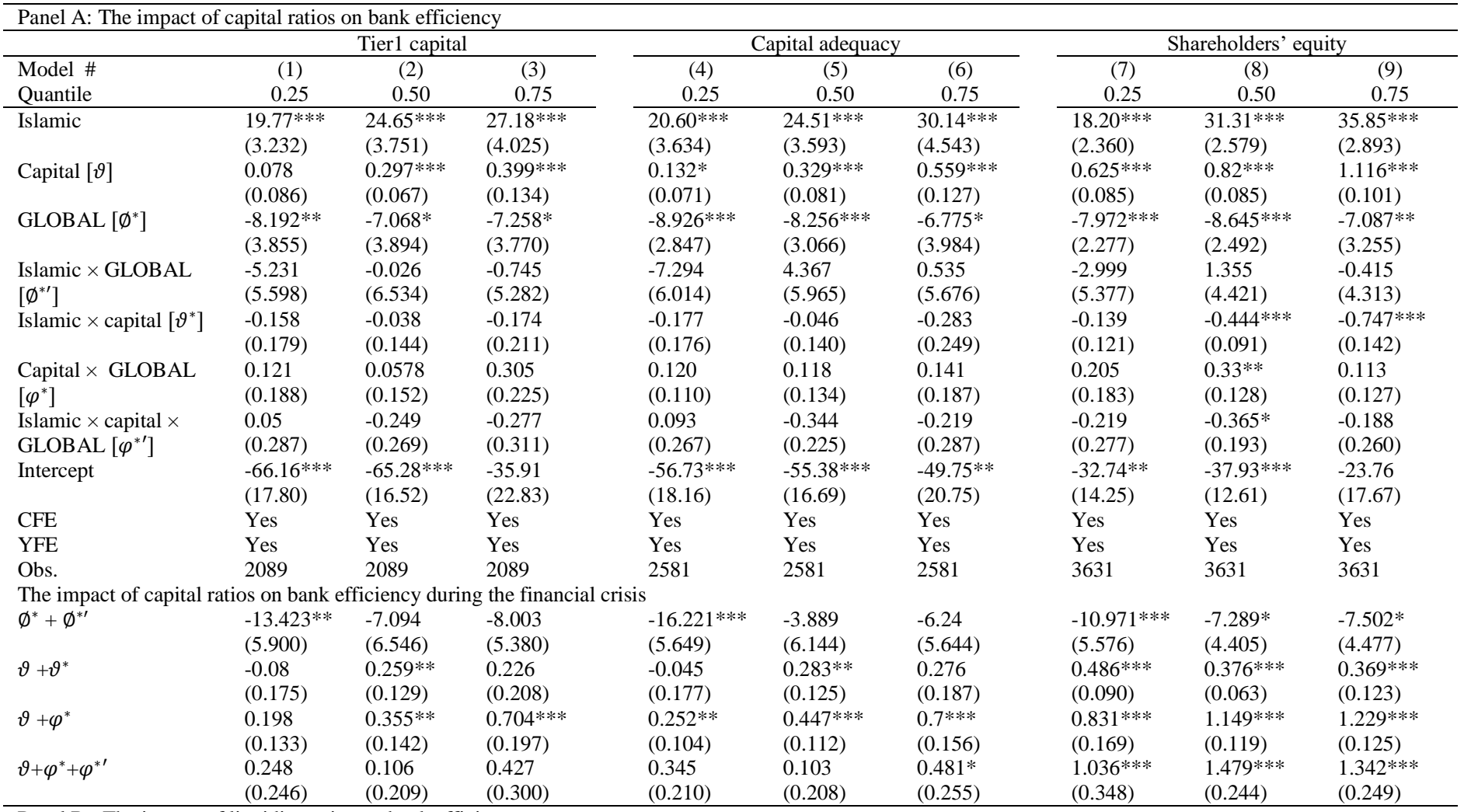

Panel B: The impact of liquidity ratios on bank efficiency

\begin{tabular}{|c|c|c|c|c|c|c|c|c|c|}
\hline \multirow[b]{2}{*}{ Model \# } & \multicolumn{3}{|c|}{ Maturity match } & \multicolumn{3}{|c|}{ Liquid assets to assets } & \multicolumn{3}{|c|}{ Liquid assets to total deposits } \\
\hline & (1) & (2) & (3) & (4) & (5) & (6) & (7) & (8) & (9) \\
\hline Quantile & 0.25 & 0.50 & 0.75 & 0.25 & 0.50 & 0.75 & 0.25 & 0.50 & 0.75 \\
\hline Islamic & $\begin{array}{l}19.27 * * * \\
(2.092)\end{array}$ & $\begin{array}{l}28.10^{* * * *} \\
(2.795)\end{array}$ & $\begin{array}{l}28.10 * * * \\
(2.795)\end{array}$ & $\begin{array}{l}22.28 * * * \\
(3.963)\end{array}$ & $\begin{array}{l}30.03 * * * \\
(4.501)\end{array}$ & $\begin{array}{l}26.96 * * * \\
(2.473)\end{array}$ & $\begin{array}{l}25.12 * * * \\
(7.879)\end{array}$ & $\begin{array}{l}33.76 * * * \\
(3.734)\end{array}$ & $\begin{array}{l}31.61 * * * \\
(3.645)\end{array}$ \\
\hline 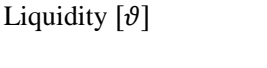 & $\begin{array}{l}0.103 * * * \\
(0.016)\end{array}$ & $\begin{array}{l}0.143 * * * \\
(0.012)\end{array}$ & $\begin{array}{l}0.128 * * * \\
(0.016)\end{array}$ & $\begin{array}{l}-0.006 \\
(0.027)\end{array}$ & $\begin{array}{l}0.049 \\
(0.035)\end{array}$ & $\begin{array}{l}0.055 \\
(0.048)\end{array}$ & $\begin{array}{l}0.032 \\
(0.032)\end{array}$ & $\begin{array}{l}0.098 * * \\
(0.038)\end{array}$ & $\begin{array}{l}0.11 * * * \\
(0.035)\end{array}$ \\
\hline GLOBAL $\left[\emptyset^{*}\right]$ & $\begin{array}{l}-7.388 * * * \\
(1.748)\end{array}$ & $\begin{array}{l}-5.321 * * \\
(2.091)\end{array}$ & $\begin{array}{l}-3.131 \\
(2.988)\end{array}$ & $\begin{array}{l}-8.594 * * * \\
(2.122)\end{array}$ & $\begin{array}{l}-6.186 * * \\
(2.605)\end{array}$ & $\begin{array}{l}-0.468 \\
(2.862)\end{array}$ & $\begin{array}{l}-10.02 * * * \\
(2.523)\end{array}$ & $\begin{array}{l}-8.047 * * * \\
(2.265)\end{array}$ & $\begin{array}{l}-3.738 \\
(3.281)\end{array}$ \\
\hline $\begin{array}{l}\text { Islamic } \times \text { GLOBAL } \\
{\left[\emptyset^{*^{\prime}}\right]}\end{array}$ & $\begin{array}{l}-6.292 * \\
(3.267)\end{array}$ & $\begin{array}{l}-2.204 \\
(4.035)\end{array}$ & $\begin{array}{l}-3.302 \\
(2.683)\end{array}$ & $\begin{array}{l}-22.05 * * * \\
(7.379)\end{array}$ & $\begin{array}{l}-9.817 \\
(6.297)\end{array}$ & $\begin{array}{l}-4.114 \\
(3.174)\end{array}$ & $\begin{array}{l}-1.039 \\
(10.17)\end{array}$ & $\begin{array}{l}-2.217 \\
(5.441)\end{array}$ & $\begin{array}{l}-1.89 \\
(3.839)\end{array}$ \\
\hline $\begin{array}{l}\text { Islamic } \times \text { Liquidity } \\
{\left[\vartheta^{*}\right]}\end{array}$ & $\begin{array}{l}-0.054 * \\
(0.028)\end{array}$ & $\begin{array}{l}-0.086^{* * * *} \\
(0.022)\end{array}$ & $\begin{array}{l}-0.077 * * * \\
(0.025)\end{array}$ & $\begin{array}{l}-0.218^{*} \\
(0.126)\end{array}$ & $\begin{array}{l}-0.131 \\
(0.152)\end{array}$ & $\begin{array}{l}-0.084 \\
(0.079)\end{array}$ & $\begin{array}{l}-0.028 \\
(0.253)\end{array}$ & $\begin{array}{l}-0.063 \\
(0.103)\end{array}$ & $\begin{array}{l}-0.107 * \\
(0.060)\end{array}$ \\
\hline $\begin{array}{l}\text { Liquidity } \times \text { GLOBAL } \\
{\left[\varphi^{*}\right]}\end{array}$ & $\begin{array}{l}0.027 \\
(0.027)\end{array}$ & $\begin{array}{l}0.013 \\
(0.024)\end{array}$ & $\begin{array}{l}0.012 \\
(0.030)\end{array}$ & $\begin{array}{l}0.096 * * \\
(0.047)\end{array}$ & $\begin{array}{l}0.023 \\
(0.055)\end{array}$ & $\begin{array}{l}0.009 \\
(0.078)\end{array}$ & $\begin{array}{l}0.074 \\
(0.050)\end{array}$ & $\begin{array}{l}0.05 \\
(0.055)\end{array}$ & $\begin{array}{l}0.027 \\
(0.066)\end{array}$ \\
\hline $\begin{array}{l}\text { Islamic } \times \text { Liquidity } \times \\
\text { GLOBAL }\left[\varphi^{* \prime}\right]\end{array}$ & $\begin{array}{l}-0.013 \\
(0.052)\end{array}$ & $\begin{array}{l}-0.021 \\
(0.057)\end{array}$ & $\begin{array}{l}-0.032 \\
(0.045)\end{array}$ & $\begin{array}{l}0.62 * * \\
(0.253)\end{array}$ & $\begin{array}{l}0.259 \\
(0.195)\end{array}$ & $\begin{array}{l}-0.018 \\
(0.130)\end{array}$ & $\begin{array}{l}0.033 \\
(0.273)\end{array}$ & $\begin{array}{l}-0.027 \\
(0.126)\end{array}$ & $\begin{array}{l}-0.027 \\
(0.091)\end{array}$ \\
\hline Intercept & $\begin{array}{l}-42.79 * * * \\
(12.29)\end{array}$ & $\begin{array}{l}-29.20 * * \\
(13.03)\end{array}$ & $\begin{array}{l}-8.217 \\
(20.06)\end{array}$ & $\begin{array}{l}-19.02 \\
(14.59)\end{array}$ & $\begin{array}{l}-22.23 \\
(14.78)\end{array}$ & $\begin{array}{l}15.15 \\
(20.90)\end{array}$ & $\begin{array}{l}-33.78 \\
(23.26)\end{array}$ & $\begin{array}{l}-16.99 \\
(15.72)\end{array}$ & $\begin{array}{l}12.14 \\
(22.19)\end{array}$ \\
\hline CFE & Yes & Yes & Yes & Yes & Yes & Yes & Yes & Yes & Yes \\
\hline YFE & Yes & Yes & Yes & Yes & Yes & Yes & Yes & Yes & Yes \\
\hline Obs. & 3623 & 3623 & 3623 & 3625 & 3625 & 3625 & 2585 & 2585 & 2585 \\
\hline The impact of liquidity & tios on bank & fficiency du & ng the finan & & & & & & \\
\hline$\emptyset^{*}+\emptyset^{* \prime}$ & $\begin{array}{l}-13.68 * * * \\
(3.978)\end{array}$ & $\begin{array}{l}-7.525 * \\
(4.009)\end{array}$ & $\begin{array}{l}-6.433 * * \\
(3.106)\end{array}$ & $\begin{array}{l}-30.645^{* * * *} \\
(7.459)\end{array}$ & $\begin{array}{l}-16.004 * * * \\
(5.492)\end{array}$ & $\begin{array}{l}-4.581 \\
(3.541)\end{array}$ & $\begin{array}{l}-11.06 \\
(8.100)\end{array}$ & $\begin{array}{l}-10.264 * \\
(5.285)\end{array}$ & $\begin{array}{l}-5.628 \\
(3.899)\end{array}$ \\
\hline$\vartheta+\vartheta^{*}$ & $\begin{array}{l}0.049 * * \\
(0.021)\end{array}$ & $\begin{array}{l}0.057 * * * \\
(0.017)\end{array}$ & $\begin{array}{l}0.051 * * * \\
(0.016)\end{array}$ & $\begin{array}{l}-0.224 * \\
(0.122)\end{array}$ & $\begin{array}{l}-0.082 \\
(0.151)\end{array}$ & $\begin{array}{l}-0.029 \\
(0.065)\end{array}$ & $\begin{array}{l}0.004 \\
(0.248)\end{array}$ & $\begin{array}{l}0.035 \\
(0.099)\end{array}$ & $\begin{array}{l}0.002 \\
(0.048)\end{array}$ \\
\hline$\vartheta+\varphi^{*}$ & $\begin{array}{l}0.139 * * * \\
(0.020)\end{array}$ & $\begin{array}{l}0.156 * * * \\
(0.023)\end{array}$ & $\begin{array}{l}0.141 * * * \\
(0.029)\end{array}$ & $\begin{array}{l}0.09 * * \\
(0.045)\end{array}$ & $\begin{array}{l}0.072 \\
(0.050)\end{array}$ & $\begin{array}{l}0.064 \\
(0.077)\end{array}$ & $\begin{array}{l}0.105 * * \\
(0.042)\end{array}$ & $\begin{array}{l}0.148 * * * \\
(0.047)\end{array}$ & $\begin{array}{l}0.137 * * \\
(0.067)\end{array}$ \\
\hline$\vartheta+\varphi^{*}+\varphi^{* \prime}$ & $\begin{array}{l}0.117 * * \\
(0.049)\end{array}$ & $\begin{array}{l}0.136 * * \\
(0.055)\end{array}$ & $\begin{array}{l}0.109 * * * \\
(0.035)\end{array}$ & $\begin{array}{l}0.71 * * * \\
(0.253)\end{array}$ & $\begin{array}{l}0.331 * \\
(0.196)\end{array}$ & $\begin{array}{l}0.045 \\
(0.114)\end{array}$ & $\begin{array}{l}0.138 \\
(0.268)\end{array}$ & $\begin{array}{l}0.121 \\
(0.123)\end{array}$ & $\begin{array}{l}0.109 * \\
(0.065)\end{array}$ \\
\hline
\end{tabular}

Note: This table documents the capital and the liquidity determinants of efficiency by comparing Islamic and conventional banks using conditional quantile regressions for the period from 2005 to 2012. The dependent variable is pure technical efficiency (loan loss provision). It is computed by comparing banks to their own efficiency frontier. GLOBAL is a dummy variable that equals 1 for the years 2008-2009 and zero otherwise. BC and CC represent bank level and country level characteristics. CFE and YFE represent country and year fixed effect dummy variables. We present the $25^{\text {th }}, 50^{\text {th }}$, and $75^{\text {th }}$ quantile of our dependent variable. Standard errors are clustered at the bank level and are reported in parentheses below their coefficient estimates. *, **, and *** represent significance at the $10 \%, 5 \%$, and $1 \%$ level, respectively. 
Table 7

The effect of capital and liquidity on bank efficiency during the Arab spring

\begin{tabular}{|c|c|c|c|c|c|c|c|c|c|}
\hline \multicolumn{10}{|c|}{ Panel A: The impact of capital ratios on bank efficiency } \\
\hline Model \# & (1) & (2) & (3) & (4) & (5) & (6) & (7) & $(8)$ & (9) \\
\hline Quantile & 0.25 & 0.50 & 0.75 & 0.25 & 0.50 & 0.75 & 0.25 & 0.50 & 0.75 \\
\hline Islamic & $\begin{array}{l}17.76 * * * \\
(2.678)\end{array}$ & $\begin{array}{l}24.74 * * * \\
(3.154)\end{array}$ & $\begin{array}{l}26.38 * * * \\
(3.493)\end{array}$ & $\begin{array}{l}18.0 * * * \\
(3.027)\end{array}$ & $\begin{array}{l}27.27 * * * \\
(3.417)\end{array}$ & $\begin{array}{l}31.49 * * * \\
(3.217)\end{array}$ & $\begin{array}{l}16.71 * * * \\
(2.362)\end{array}$ & $\begin{array}{l}31.6 * * * \\
(2.402)\end{array}$ & $\begin{array}{l}35.17 * * * \\
(2.962)\end{array}$ \\
\hline 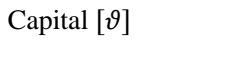 & $\begin{array}{l}0.086 \\
(0.072)\end{array}$ & $\begin{array}{l}0.295 * * * \\
(0.061)\end{array}$ & $\begin{array}{l}0.454 * * * \\
(0.143)\end{array}$ & $\begin{array}{l}0.195 * * \\
(0.079)\end{array}$ & $\begin{array}{l}0.347 * * * \\
(0.068)\end{array}$ & $\begin{array}{l}0.674 * * * \\
(0.117)\end{array}$ & $\begin{array}{l}0.658 * * * \\
(0.082)\end{array}$ & $\begin{array}{l}0.927 * * * \\
(0.065)\end{array}$ & $\begin{array}{l}1.164 * * * \\
(0.090)\end{array}$ \\
\hline Arab spring $\left[\emptyset^{*}\right]$ & $\begin{array}{l}-8.008 \\
(6.481)\end{array}$ & $\begin{array}{l}-5.670 \\
(5.218)\end{array}$ & $\begin{array}{l}-7.127 \\
(6.928)\end{array}$ & $\begin{array}{l}4.06 \\
(3.137)\end{array}$ & $\begin{array}{l}1.604 \\
(3.706)\end{array}$ & $\begin{array}{l}2.83 \\
(5.753)\end{array}$ & $\begin{array}{l}1.052 \\
(2.761)\end{array}$ & $\begin{array}{l}2.591 \\
(3.322)\end{array}$ & $\begin{array}{l}1.258 \\
(3.959)\end{array}$ \\
\hline $\begin{array}{l}\text { Islamic } \times \text { Arab } \\
\text { spring }\left[\emptyset^{*^{\prime}}\right]\end{array}$ & $\begin{array}{l}-4.339 \\
(14.90)\end{array}$ & $\begin{array}{l}9.004 \\
(14.01)\end{array}$ & $\begin{array}{l}14.87 \\
(14.24)\end{array}$ & $\begin{array}{l}-9.22 \\
(14.06)\end{array}$ & $\begin{array}{l}-8.297 \\
(12.42)\end{array}$ & $\begin{array}{l}5.82 \\
(9.149)\end{array}$ & $\begin{array}{l}-2.645 \\
(8.361)\end{array}$ & $\begin{array}{l}-4.772 \\
(9.605)\end{array}$ & $\begin{array}{l}5.608 \\
(9.843)\end{array}$ \\
\hline $\begin{array}{l}\text { Islamic } \times \text { capital } \\
{\left[\vartheta^{*}\right]}\end{array}$ & $\begin{array}{l}-0.096 \\
(0.112)\end{array}$ & $\begin{array}{l}-0.119 \\
(0.138)\end{array}$ & $\begin{array}{l}-0.213 \\
(0.177)\end{array}$ & $\begin{array}{l}-0.16 \\
(0.134)\end{array}$ & $\begin{array}{l}-0.216^{*} \\
(0.130)\end{array}$ & $\begin{array}{l}-0.449 * * * \\
(0.145)\end{array}$ & $\begin{array}{l}-0.168 \\
(0.134)\end{array}$ & $\begin{array}{l}-0.547 * * * \\
(0.092)\end{array}$ & $\begin{array}{l}-0.785^{* * * *} \\
(0.143)\end{array}$ \\
\hline $\begin{array}{l}\text { Capital } \times \text { Arab } \\
\text { spring }\left[\varphi^{*}\right]\end{array}$ & $\begin{array}{l}0.619 \\
(0.390)\end{array}$ & $\begin{array}{l}0.413 \\
(0.322)\end{array}$ & $\begin{array}{l}0.169 \\
(0.430)\end{array}$ & $\begin{array}{l}-0.138 \\
(0.161)\end{array}$ & $\begin{array}{l}-0.063 \\
(0.180)\end{array}$ & $\begin{array}{l}-0.344 \\
(0.270)\end{array}$ & $\begin{array}{l}-0.025 \\
(0.219)\end{array}$ & $\begin{array}{l}-0.262 \\
(0.286)\end{array}$ & $\begin{array}{l}-0.267 \\
(0.323)\end{array}$ \\
\hline Islamic $\times$ capital $\times$ & -0.229 & -0.245 & -0.361 & 0.473 & 0.373 & 0.214 & 0.178 & 0.409 & 0.072 \\
\hline Arab spring $\left[\varphi^{* \prime}\right]$ & $(0.609)$ & $(0.572)$ & $(0.686)$ & $(0.510)$ & $(0.436)$ & $(0.411)$ & $(0.413)$ & $(0.465)$ & $(0.521)$ \\
\hline Intercept & $\begin{array}{l}-63.68 * * * \\
(19.13)\end{array}$ & $\begin{array}{l}-60.47 * * * \\
(18.37)\end{array}$ & $\begin{array}{l}-33.28 \\
(22.44)\end{array}$ & $\begin{array}{l}-53.50 * * * \\
(19.99)\end{array}$ & $\begin{array}{l}-55.10 * * * \\
(15.20)\end{array}$ & $\begin{array}{l}-50.18 * * \\
(20.30)\end{array}$ & $\begin{array}{l}-38.33 * * \\
(15.00)\end{array}$ & $\begin{array}{l}-42.01 * * * \\
(10.85)\end{array}$ & $\begin{array}{l}-30.14 * \\
(16.32)\end{array}$ \\
\hline CFE & Yes & Yes & Yes & Yes & Yes & Yes & Yes & Yes & Yes \\
\hline YFE & Yes & Yes & Yes & Yes & Yes & Yes & Yes & Yes & Yes \\
\hline Obs. & 2089 & 2089 & 2089 & 2581 & 2581 & 2581 & 3631 & 3631 & 3631 \\
\hline The impact of capit & atios on ban & efficiency d & ig the Arab & & & & & & \\
\hline$\emptyset^{*}+\emptyset^{* \prime}$ & $\begin{array}{l}-12.347 \\
(12.808)\end{array}$ & $\begin{array}{l}3.333 \\
(12.951)\end{array}$ & $\begin{array}{l}7.745 \\
(11.772)\end{array}$ & $\begin{array}{l}-5.16 \\
(11.581)\end{array}$ & $\begin{array}{l}-6.693 \\
(13.643)\end{array}$ & $\begin{array}{l}8.649 \\
(10.498)\end{array}$ & $\begin{array}{l}-1.592 \\
(7.280)\end{array}$ & $\begin{array}{l}-2.181 \\
(9.639)\end{array}$ & $\begin{array}{l}6.865 \\
(8.352)\end{array}$ \\
\hline$\vartheta+\vartheta^{*}$ & $\begin{array}{c}0.01 \\
(0.102)\end{array}$ & $\begin{array}{l}0.176 \\
(0.126)\end{array}$ & $\begin{array}{l}0.24 * \\
(0.144)\end{array}$ & $\begin{array}{l}0.035 \\
(0.106)\end{array}$ & $\begin{array}{l}0.131 \\
(0.103)\end{array}$ & $\begin{array}{l}0.224 * * \\
(0.107)\end{array}$ & $\begin{array}{l}0.49 * * * \\
(0.105)\end{array}$ & $\begin{array}{l}0.38 * * * \\
(0.064)\end{array}$ & $\begin{array}{l}0.379 * * * \\
(0.123)\end{array}$ \\
\hline$\vartheta+\varphi^{*}$ & $\begin{array}{l}0.705^{*} \\
(0.402)\end{array}$ & $\begin{array}{l}0.708 * * \\
(0.311)\end{array}$ & $\begin{array}{l}0.623 \\
(0.410)\end{array}$ & $\begin{array}{l}0.057 \\
(0.155)\end{array}$ & $\begin{array}{l}0.284 \\
(0.174)\end{array}$ & $\begin{array}{l}0.329 \\
(0.250)\end{array}$ & $\begin{array}{l}0.633 * * * \\
(0.199)\end{array}$ & $\begin{array}{l}0.666^{* *} \\
(0.277)\end{array}$ & $\begin{array}{l}0.897 \text { *** } \\
(0.320)\end{array}$ \\
\hline$\vartheta+\varphi^{*}+\varphi^{* \prime}$ & $\begin{array}{c}0.476 \\
(0.481)\end{array}$ & $\begin{array}{l}0.463 \\
(0.503)\end{array}$ & $\begin{array}{l}0.262 \\
(0.562)\end{array}$ & $\begin{array}{l}0.53 \\
(0.487)\end{array}$ & $\begin{array}{l}0.656 \\
(0.426)\end{array}$ & $\begin{array}{l}0.543 \\
(0.348)\end{array}$ & $\begin{array}{l}0.811 * * \\
(0.389)\end{array}$ & $\begin{array}{l}1.075^{* * * *} \\
(0.346)\end{array}$ & $\begin{array}{l}0.969 * * \\
(0.447)\end{array}$ \\
\hline
\end{tabular}

Panel B: The impact of liquidity ratios on bank efficiency

\begin{tabular}{|c|c|c|c|c|c|c|c|c|c|}
\hline \multirow{3}{*}{$\begin{array}{l}\text { Model \# } \\
\text { Quantile }\end{array}$} & \multicolumn{3}{|c|}{ Maturity match } & \multicolumn{3}{|c|}{ Liquid assets to assets } & \multicolumn{3}{|c|}{ Liquid assets to total deposits } \\
\hline & (1) & $(2)$ & (3) & (4) & $(5)$ & (6) & (7) & $(8)$ & (9) \\
\hline & 0.25 & 0.50 & 0.75 & 0.25 & 0.50 & 0.75 & 0.25 & 0.50 & 0.75 \\
\hline \multirow[t]{2}{*}{ Islamic } & $16.29 * * *$ & $27.64 * * *$ & $26.00 * * *$ & $17.37 * * *$ & $23.10 * * *$ & $24.05 * * *$ & $23.45 * * *$ & $33.02 * * *$ & $31.19 * * *$ \\
\hline & $(1.797)$ & $(2.059)$ & $(2.070)$ & $(3.320)$ & $(4.203)$ & $(2.411)$ & $(4.721)$ & $(2.965)$ & $(2.703)$ \\
\hline \multirow[t]{2}{*}{ Liquidity $[\vartheta]$} & $0.109 * * *$ & $0.142 * * *$ & $0.132 * * *$ & 0.014 & $0.05^{*}$ & 0.032 & $0.057 * * *$ & $0.106 * * *$ & $0.11 * * *$ \\
\hline & $(0.014)$ & $(0.010)$ & $(0.014)$ & $(0.030)$ & $(0.029)$ & $(0.046)$ & $(0.021)$ & $(0.033)$ & $(0.038)$ \\
\hline \multirow{2}{*}{ Arab spring $\left[\varnothing^{*}\right]$} & 0.997 & -0.337 & -4.871 & 0.327 & -2.88 & $-8.279 * *$ & 2.731 & -0.512 & -5.708 \\
\hline & $(2.227)$ & (2.195) & (3.329) & $(2.442)$ & (3.010) & $(3.545)$ & $(4.775)$ & (3.543) & (4.203) \\
\hline \multirow{4}{*}{$\begin{array}{l}\text { Islamic } \times \text { Arab } \\
\text { spring }\left[\emptyset^{*^{\prime}}\right] \\
\text { Islamic } \times \text { Liquidity } \\
{\left[\vartheta^{*}\right]}\end{array}$} & 8.15 & 4.221 & $11.40 *$ & 5.455 & 12.77 & 10.31 & -13.56 & 5.404 & -2.844 \\
\hline & (7.368) & $(8.326)$ & (6.104) & $(16.22)$ & (15.28) & (8.874) & $(37.11)$ & (17.48) & (15.38) \\
\hline & $-0.055 * * *$ & $-0.095 * * *$ & $-0.078 * * *$ & -0.107 & 0.055 & -0.068 & 0.05 & -0.054 & $-0.11 * * *$ \\
\hline & $(0.017)$ & $(0.014)$ & $(0.021)$ & $(0.115)$ & $(0.130)$ & $(0.071)$ & $(0.138)$ & $(0.051)$ & $(0.038)$ \\
\hline \multirow{2}{*}{$\begin{array}{l}\text { Liquidity } \times \text { Arab } \\
\text { spring }\left[\varphi^{*}\right]\end{array}$} & 0.012 & -0.008 & 0.037 & 0.015 & 0.075 & 0.176 & -0.042 & -0.057 & -0.054 \\
\hline & $(0.038)$ & $(0.047)$ & (0.069) & $(0.076)$ & $(0.093)$ & (0.109) & $(0.145)$ & $(0.091)$ & $(0.113)$ \\
\hline \multirow{4}{*}{$\begin{array}{l}\text { Islamic } \times \text { Liquidity } \\
\times \text { Arab spring }\left[\varphi^{* \prime}\right] \\
\text { Intercept }\end{array}$} & -0.087 & -0.012 & -0.088 & -0.031 & -0.208 & -0.109 & 0.126 & -0.092 & 0.148 \\
\hline & $(0.097)$ & $(0.079)$ & $(0.081)$ & $(0.518)$ & $(0.474)$ & $(0.260)$ & $(0.868)$ & $(0.374)$ & $(0.439)$ \\
\hline & $-41.46 * * *$ & $-30.58 * *$ & -5.396 & -18.25 & -24.76 & 17.84 & -29.85 & -23.74 & -4.055 \\
\hline & (14.77) & $(12.45)$ & (20.24) & (13.96) & (15.71) & (18.68) & (24.49) & (18.89) & (21.68) \\
\hline \multirow{3}{*}{$\begin{array}{l}\text { CFE } \\
\text { YFE } \\
\text { Obs. }\end{array}$} & Yes & Yes & Yes & Yes & Yes & Yes & Yes & Yes & Yes \\
\hline & Yes & Yes & Yes & Yes & Yes & Yes & Yes & Yes & Yes \\
\hline & 3623 & 3623 & 3623 & 3625 & 3625 & 3625 & 2585 & 2585 & 2585 \\
\hline \multicolumn{10}{|c|}{ The impact of liquidity ratios on bank efficiency during the Arab Spring } \\
\hline \multirow[t]{2}{*}{$\emptyset^{*}+\emptyset^{* \prime}$} & 9.147 & 3.884 & 6.523 & 5.782 & 9.887 & 2.2026 & -10.824 & -8.552 & -8.552 \\
\hline & $(7.858)$ & $(8.589)$ & $(5.388)$ & $(15.367)$ & $(12.473)$ & $(7.677)$ & $(33.751)$ & $(12.028)$ & $(17.275)$ \\
\hline \multirow[t]{2}{*}{$\vartheta+\vartheta^{*}$} & $0.054 * * *$ & $0.046 * * *$ & $0.054 * * *$ & -0.092 & 0.105 & -0.035 & 0.107 & 0.052 & -0.000 \\
\hline & $(0.011)$ & $(0.013)$ & $(0.016)$ & $(0.112)$ & $(0.134)$ & $(0.053)$ & $(0.137)$ & $(0.039)$ & $(0.016)$ \\
\hline \multirow[t]{2}{*}{$\vartheta+\varphi^{*}$} & $0.121 * * *$ & $0.134 * * *$ & $0.169 * *$ & 0.03 & 0.125 & $0.208 * *$ & 0.016 & 0.049 & 0.055 \\
\hline & $(0.035)$ & $(0.046)$ & $(0.068)$ & $(0.072)$ & $(0.090)$ & $(0.102)$ & $(0.143)$ & $(0.085)$ & $(0.114)$ \\
\hline \multirow[t]{2}{*}{$\vartheta+\varphi^{*}+\varphi^{* \prime}$} & 0.034 & $0.122 *$ & $0.081 *$ & -0.001 & -0.082 & 0.099 & 0.142 & -0.043 & 0.204 \\
\hline & $(0.094)$ & $(0.063)$ & $(0.045)$ & $(0.503)$ & $(0.467)$ & $(0.244)$ & $(0.831)$ & $(0.372)$ & $(0.434)$ \\
\hline
\end{tabular}

Note: This table documents the capital and the liquidity determinants of efficiency by comparing Islamic and conventional banks using conditional quantile regressions for the period from 2005 to 2012 . The dependent variable is pure technical efficiency (loan loss provision). It is computed by comparing banks to their own efficiency frontier. Arab spring is a variable that equals 1 if a country is severely affected by the Arab spring and 0 otherwise. BC and CC represent bank level and country level characteristics. CFE and YFE represent country and year fixed effect dummy variables. We present the $25^{\text {th }}, 50^{\text {th }}$, and $75^{\text {th }}$ quantile of our dependent variable. Standard errors are clustered at the bank level and are reported in parentheses below their coefficient estimates. *, **, and *** represent significance at the $10 \%, 5 \%$, and $1 \%$ level, respectively. 
Other combinations of bank inputs (Models 1-6) and other subsamples (Models 7-12).

\begin{tabular}{|c|c|c|c|c|c|c|c|c|c|c|c|c|c|c|c|c|}
\hline & \multicolumn{3}{|c|}{$\begin{array}{l}\text { Technical efficiency (shareholders' } \\
\text { equity) }\end{array}$} & & \multicolumn{3}{|c|}{ Technical efficiency (no control for risk) } & \multirow[b]{4}{*}{$\mathrm{N}$} & \multicolumn{8}{|c|}{ Technical efficiency (loan loss provision) } \\
\hline & Full sample & & & \multirow[b]{3}{*}{$\mathrm{N}$} & \multicolumn{3}{|c|}{ Full sample } & & \multirow{2}{*}{\multicolumn{3}{|c|}{ Excluding UK }} & \multirow[b]{3}{*}{$\mathrm{N}$} & \multicolumn{3}{|c|}{ Excluding the UK and Singapore } & \multirow[b]{3}{*}{$\mathrm{N}$} \\
\hline Model \# & (1) & (2) & (3) & & (4) & (5) & (6) & & (7) & & & & \multirow{2}{*}{$\begin{array}{l}(10) \\
0.25\end{array}$} & \multirow{2}{*}{$\begin{array}{l}(11) \\
0.50\end{array}$} & \multirow{2}{*}{$\begin{array}{l}(12) \\
0.75 \\
\end{array}$} & \\
\hline Quantile & 0.25 & 0.50 & 0.75 & & 0.25 & 0.50 & 0.75 & & 0.25 & 0.50 & 0.75 & & & & & \\
\hline Islamic & $\begin{array}{l}33.5^{* * * *} \\
(4.364)\end{array}$ & $\begin{array}{l}39.88^{* * * *} \\
(3.548)\end{array}$ & $\begin{array}{l}37.49 * * * \\
(3.751)\end{array}$ & & $\begin{array}{l}14.43 * * * \\
(3.805)\end{array}$ & $\begin{array}{l}24.20 * * * \\
(6.229)\end{array}$ & $\begin{array}{l}35.21 * * * \\
(4.527)\end{array}$ & & $\begin{array}{l}-0.158 \\
(6.888)\end{array}$ & $\begin{array}{l}5.182 \\
(5.208)\end{array}$ & $\begin{array}{l}8.966^{* * *} \\
(3.618)\end{array}$ & & $\begin{array}{l}-2.68 \\
(-0.78)\end{array}$ & $\begin{array}{l}3.516 \\
(1.02)\end{array}$ & $\begin{array}{l}9.819^{*} \\
(2.14)\end{array}$ & \\
\hline Tier1 capital & $\begin{array}{l}-0.153 \\
(0.157)\end{array}$ & $\begin{array}{l}0.038 \\
(0.140)\end{array}$ & $\begin{array}{l}0.251 \\
(0.180)\end{array}$ & & $\begin{array}{l}0.101 \\
(0.134)\end{array}$ & $\begin{array}{l}0.286 * * * \\
(0.104)\end{array}$ & $\begin{array}{l}0.411^{* *} \\
(0.203)\end{array}$ & & $\begin{array}{l}0.053 \\
(0.158)\end{array}$ & $\begin{array}{l}0.331 * * * \\
(0.127)\end{array}$ & $\begin{array}{l}0.308^{*} \\
(0.163)\end{array}$ & & $\begin{array}{l}0.217 \\
(1.55)\end{array}$ & $\begin{array}{l}0.352 * * * \\
(3.43)\end{array}$ & $\begin{array}{l}0.510^{* * * *} \\
(4.07)\end{array}$ & \\
\hline Tier1 capital $\times$ Islamic & $\begin{array}{l}0.008 \\
(0.178)\end{array}$ & $\begin{array}{l}-0.12 \\
(0.185)\end{array}$ & $\begin{array}{l}-0.149 \\
(0.223)\end{array}$ & 2140 & $\begin{array}{l}0.091 \\
(0.197)\end{array}$ & $\begin{array}{l}-0.013 \\
(0.274)\end{array}$ & $\begin{array}{l}-0.15 \\
(0.201)\end{array}$ & 2140 & $\begin{array}{l}0.147 \\
(0.388)\end{array}$ & $\begin{array}{l}0.006 \\
(0.264)\end{array}$ & $\begin{array}{l}-0.044 \\
(0.161)\end{array}$ & 1879 & $\begin{array}{l}0.061 \\
(0.34)\end{array}$ & $\begin{array}{l}-0.022 \\
(-0.19)\end{array}$ & $\begin{array}{l}-0.158 \\
(-0.56)\end{array}$ & 1829 \\
\hline \multicolumn{3}{|c|}{$\vartheta_{\mathrm{CAP}}:$ Wald test (F-stat.): Q[0.25] = Q $[0.75]$} & N/A & & & & N/A & & & & $10.73 * *$ & & & & N/A & \\
\hline \multicolumn{16}{|c|}{ The impact of capital on Islamic banks' efficiency $\left[\vartheta_{\mathrm{CAP}}+\vartheta_{\text {inter }}^{*}\right]$ compared to conventional banks $\left[\vartheta_{\text {CAP }}\right]$} & \\
\hline & $\begin{array}{l}-0.145 \\
(0.140)\end{array}$ & $\begin{array}{l}-0.081 \\
(0.135)\end{array}$ & $\begin{array}{l}0.102 \\
(0.139)\end{array}$ & & $\begin{array}{l}0.192 \\
(0.141)\end{array}$ & $\begin{array}{l}0.273 \\
(0.273)\end{array}$ & $\begin{array}{l}0.26^{* * * *} \\
(0.060)\end{array}$ & & $\begin{array}{l}0.199 \\
(0.373)\end{array}$ & $\begin{array}{l}0.337 \\
(0.242)\end{array}$ & $\begin{array}{l}0.264 * * * \\
(0.040)\end{array}$ & & $0.277 * * *$ & $\begin{array}{l}0.329 * * * \\
(0059)\end{array}$ & $\begin{array}{l}0.352 \\
(0276)\end{array}$ & \\
\hline \multicolumn{3}{|c|}{$\vartheta_{\text {CAP }}+\vartheta_{\text {inter }}^{*}:$ Wald test (F-stat.): Q $[0.25]=\mathrm{Q}[0.75]$} & N/A & & & & N/A & & & & 0.01 & & & & N/A & \\
\hline Islamic & $\begin{array}{l}31.83^{* * * *} \\
(5.432)\end{array}$ & $\begin{array}{l}37.41 * * * \\
(3.183)\end{array}$ & $\begin{array}{l}36.41 * * * \\
(2.649)\end{array}$ & & $\begin{array}{l}14.03 * * * * \\
(4.512)\end{array}$ & $\begin{array}{l}23.44 * * * * \\
(4.498)\end{array}$ & $\begin{array}{l}33.76 * * * \\
(3.901)\end{array}$ & & $\begin{array}{l}3.138 \\
(4.775)\end{array}$ & $\begin{array}{l}8.491^{* *} \\
(3.840)\end{array}$ & $\begin{array}{l}14.12 * \\
(7.353)\end{array}$ & & $\begin{array}{l}-0.106 \\
(-0.03)\end{array}$ & $\begin{array}{l}8.299 * \\
(2.19)\end{array}$ & $\begin{array}{l}11.78^{*} \\
(2.54)\end{array}$ & \\
\hline Capital adequacy & $\begin{array}{l}-0.092 \\
(0.147)\end{array}$ & $\begin{array}{l}0.106 \\
(0.075)\end{array}$ & $\begin{array}{l}0.293 * * * \\
(0.106)\end{array}$ & & $\begin{array}{l}0.09 \\
(0.060)\end{array}$ & $\begin{array}{l}0.287 * * * \\
(0.080)\end{array}$ & $\begin{array}{l}0.403 * * * \\
(0.153)\end{array}$ & & $\begin{array}{l}0.191 \\
(0.126)\end{array}$ & $\begin{array}{l}0.396^{* * * *} \\
(0.08)\end{array}$ & $\begin{array}{l}0.508 * * * \\
(0.093)\end{array}$ & & $\begin{array}{l}0.302^{*} \\
(2.35)\end{array}$ & $\begin{array}{l}0.501 * * * \\
(6.52)\end{array}$ & $\begin{array}{l}0.524 * * * \\
(4.54)\end{array}$ & \\
\hline \multirow{2}{*}{$\begin{array}{l}\text { Capital adequacy } \times \\
\text { Islamic }\end{array}$} & 0.072 & -0.075 & -0.146 & 2645 & 0.123 & 0.088 & -0.091 & 2645 & -0.021 & -0.116 & -0.194 & 2345 & -0.037 & -0.163 & -0.118 & 2295 \\
\hline & $\begin{array}{c}(0.267) \\
0[0.25]=0[0\end{array}$ & $\begin{array}{l}(0.122) \\
75]\end{array}$ & $\begin{array}{l}(0.108) \\
\text { N/A }\end{array}$ & & $(0.204)$ & $(0.106)$ & $\begin{array}{l}(0.150) \\
\text { N/A }\end{array}$ & & & $(0.132)$ & $\begin{array}{l}(0.377) \\
\text { N/A }\end{array}$ & & $(-0.24)$ & $(-1.81)$ & $(-0.52)$ & \\
\hline $\begin{array}{l}\vartheta_{\text {CAP }}: \text { Wald test (F-stat.): } \\
\text { The impact of capital on }\end{array}$ & $\begin{array}{l}\mathrm{Q} \\
\mathrm{s} \text { slamic banks' }\end{array}$ & $\begin{array}{l}.75] \\
\text { efficiency [ } \vartheta\end{array}$ & $\begin{array}{l}\text { N/A } \\
\left.+\vartheta_{i n t e r}^{*}\right] \mathrm{cc}\end{array}$ & & & banks [9 & N/A & & & & N/A & & & & N/A & \\
\hline & & & & sared to & conventional & & & & & & & & & & & \\
\hline & -0.019 & 0.03 & $0.147 * * *$ & & 0.213 & $0.375 * * *$ & $0.312 * * *$ & & 0.171 & $0.279 * * *$ & 0.313 & & $0.264 * * *$ & $0.337 * * *$ & $0.406^{* *}$ & \\
\hline & & $(0.097)$ & $(0.037)$ & & $(0.192)$ & $(0.068)$ & $(0.035)$ & & $(0.275)$ & $(0.105)$ & $(0.363)$ & & $(0.077)$ & $(0.048)$ & $(0.197)$ & \\
\hline$\vartheta_{\mathrm{CAP}}+\vartheta_{\text {inter }}^{*}$ : Wald test & F-stat.): $\mathrm{Q}[0.2$ & $5]=\mathrm{Q}[0.75]$ & N/A & & & & N/A & & & & N/A & & & & N/A & \\
\hline Islamic & $33.39^{* * * *}$ & $38.84 * * *$ & $37.06^{* * *}$ & & $13.98^{* * * *}$ & $28.85^{* * * *}$ & $38.15^{* * * *}$ & & $7.371 * * *$ & $13.68 * * *$ & $16.04 * * *$ & & 3.544 & $13.08^{* * *}$ & $15.96^{* * *}$ & \\
\hline & $(4.281)$ & $(2.460)$ & (2.709) & & (3.012) & $(4.769)$ & $(4.359)$ & & $(2.584)$ & $(3.686)$ & $(3.618)$ & & $(1.28)$ & $(3.05)$ & $(4.85)$ & \\
\hline Shareholders' equity & 0.0169 & $0.290 * * *$ & $0.441 * * *$ & & $0.423 * * *$ & 0.687 *** & $0.919 * * *$ & & $0.828 * * *$ & $0.871 * * *$ & $0.897 * * *$ & & $0.834 * * *$ & $0.912 * * *$ & $0.98^{* * * *}$ & \\
\hline & $(0.087)$ & $(0.089)$ & $(0.111)$ & & $(0.081)$ & $(0.079)$ & $(0.148)$ & & $(0.090)$ & $(0.124)$ & $(0.115)$ & & $(10.75)$ & $(9.52)$ & $(4.73)$ & \\
\hline Shareholders' equity $x$ & -0.1 & $-0.234^{*}$ & $-0.372 * * *$ & 4000 & 0.06 & $-0.282^{*}$ & $-0.543 * *$ & 4000 & $-0.352 * * *$ & $-0.427 * * *$ & -0.397 & 3079 & $-0.346^{* *}$ & $-0.497^{*}$ & $-0.451 *$ & 3004 \\
\hline Islamic & $(0.207)$ & $(0.122)$ & $(0.124)$ & & $(0.119)$ & $(0.145)$ & $(0.220)$ & & $(0.128)$ & $(0.158)$ & $(0.253)$ & & $(-2.93)$ & $(-2.43)$ & $(-2.11)$ & \\
\hline$\vartheta_{\mathrm{CAP}}:$ Wald test (F-stat.): & $\mathrm{Q}[0.25]=\mathrm{Q}[0$ & .75] & $30.51 * * *$ & & & & $40.62 * * *$ & & & & 0.46 & & & & 2.64 & \\
\hline The impact of capital on & lamic banks' & efficiency $[\vartheta$ & $\left.+\vartheta_{\text {inter }}^{*}\right] \mathrm{cc}$ & ared to & conventional & banks $\left[\vartheta_{\mathrm{CAP}}\right]$ & & & & & & & & & & \\
\hline & -0.083 & 0.056 & 0.069 & & $0.483 * * *$ & $0.405^{* * * *}$ & $0.376^{* *}$ & & $0.475^{* * * *}$ & $0.444 * * *$ & $0.5^{* *}$ & & $0.488 * * *$ & $0.415^{* *}$ & $0.529 * * *$ & \\
\hline & $(0.181)$ & $(0.077)$ & $(0.055)$ & & $(0.097)$ & $(0.111)$ & $(0.189)$ & & $(0.093)$ & $(0.110)$ & $(0.245)$ & & $(0.086)$ & $(0.195)$ & $(0.112)$ & \\
\hline$\vartheta_{\mathrm{CAP}}+\vartheta_{\text {inter }}^{*}:$ Wald test & F-stat.): $\mathrm{Q}[0.25$ & ]$=Q[0.75]$ & 1.38 & & & & 0.63 & & & & 0.85 & & & & 0.59 & \\
\hline Islamic & $32.90^{* * * *}$ & $38.45 * * *$ & $36.27 * * *$ & & $16.86 * * *$ & $29.27 * * *$ & $36.39 * * *$ & & $4.755^{*}$ & $10.65 * * *$ & $13.05 * * *$ & & 2.462 & $9.401^{* *}$ & $13.47 * * *$ & \\
\hline & $\begin{array}{l}(3.000) \\
0.096 * * *\end{array}$ & $\begin{array}{l}(2.367) \\
0.119 * * *\end{array}$ & $\begin{array}{l}(2.428) \\
0.122 * * *\end{array}$ & & $\begin{array}{l}(2.946) \\
0.107 * *\end{array}$ & $\begin{array}{l}(4.194) \\
0.149 * * *\end{array}$ & $\begin{array}{l}(2.877) \\
0.167 * * *\end{array}$ & & $\begin{array}{l}(2.585) \\
0.154 * * *\end{array}$ & $\begin{array}{l}(3.009) \\
0.151 * * *\end{array}$ & $\begin{array}{l}(2.978) \\
0.145 * * *\end{array}$ & & $\begin{array}{l}(0.79) \\
0.139 * * *\end{array}$ & $\begin{array}{l}(2.62) \\
0.145 * * *\end{array}$ & $\begin{array}{l}(4.69) \\
0.166 * * *\end{array}$ & \\
\hline Maturity match & $\begin{array}{l}0.096 \text { *** } \\
(0.012)\end{array}$ & $\begin{array}{l}0.119 * * * \\
(0.009)\end{array}$ & $\begin{array}{l}0.122 * * * \\
(0.014)\end{array}$ & & $\begin{array}{l}0.107 * * \\
(0.048)\end{array}$ & $\begin{array}{l}0.149 \text { *** } \\
(0.021)\end{array}$ & $(0.025)$ & & $\begin{array}{l}0.154 * * * \\
(0.019)\end{array}$ & $\begin{array}{l}0.151^{* * * *} \\
(0.013)\end{array}$ & $\begin{array}{l}0.145 * * * \\
(0.037)\end{array}$ & & $(9.49)$ & $(13.18)$ & $\begin{array}{l}0.166^{* * * *} \\
(5.60)\end{array}$ & \\
\hline Maturity match $x$ & $\begin{array}{l}(0.012) \\
-0.063 * * *\end{array}$ & $-0.092 * * *$ & $-0.101 * * *$ & 3989 & -0.05 & $-0.093 * * *$ & $-0.116^{* * * *}$ & 3989 & $-0.083^{* * * *}$ & $-0.097 * * *$ & $-0.096 * * *$ & 3077 & $-0.08^{*}$ & $-0.088^{* * * *}$ & $-0.116^{* * * *}$ & 3003 \\
\hline Islamic & $(0.016)$ & $(0.022)$ & $(0.016)$ & & $(0.048)$ & $(0.022)$ & $(0.026)$ & & $(0.020)$ & $(0.015)$ & $(0.037)$ & & $(-2.14)$ & $(-3.86)$ & $(-4.11)$ & \\
\hline$\vartheta_{\text {LIQ }}:$ Wald test (F-stat.): & {$[0.25]=\mathrm{Q}[0.7$} & & 2.06 & & & & $5.03 * *$ & & & & 0.45 & & & & $3.19^{*}$ & \\
\hline The impact of liquidity o & Islamic banks & ' efficiency & $\left.\mathrm{Q}+\vartheta_{\text {inter }}^{*}\right]$ & ipared & convention & I banks $\left[\vartheta_{\mathrm{LIQ}}\right]$ & & & & & & & & & & \\
\hline & $0.033^{* * *} *$ & 0.026 & $0.021 * *$ & & $0.057 * * *$ & $0.056^{* *}$ & $0.05^{* * *}$ & & $0.071 * * *$ & $0.055^{* * *}$ & $0.048 * * *$ & & $0.059^{*}$ & $0.057 * * *$ & $0.049^{* * *} *$ & \\
\hline & $(0.008)$ & $(0.021)$ & $(0.009)$ & & $(0.008)$ & $(0.009)$ & $(0.009)$ & & $(0.007)$ & $(0.008)$ & $(0.011)$ & & $(0.034)$ & $(0.022)$ & $(0.008)$ & \\
\hline$\vartheta_{\text {LIQ }}+\vartheta_{\text {inter }}^{*}:$ Wald test & -stat.): Q $[0.25$ & ]$=Q[0.75]$ & 2.1 & & & & 0.27 & & & & 1.65 & & & & 0.27 & \\
\hline
\end{tabular}


Table 8 - (Continued)

Other combinations for bank inputs and subsamples

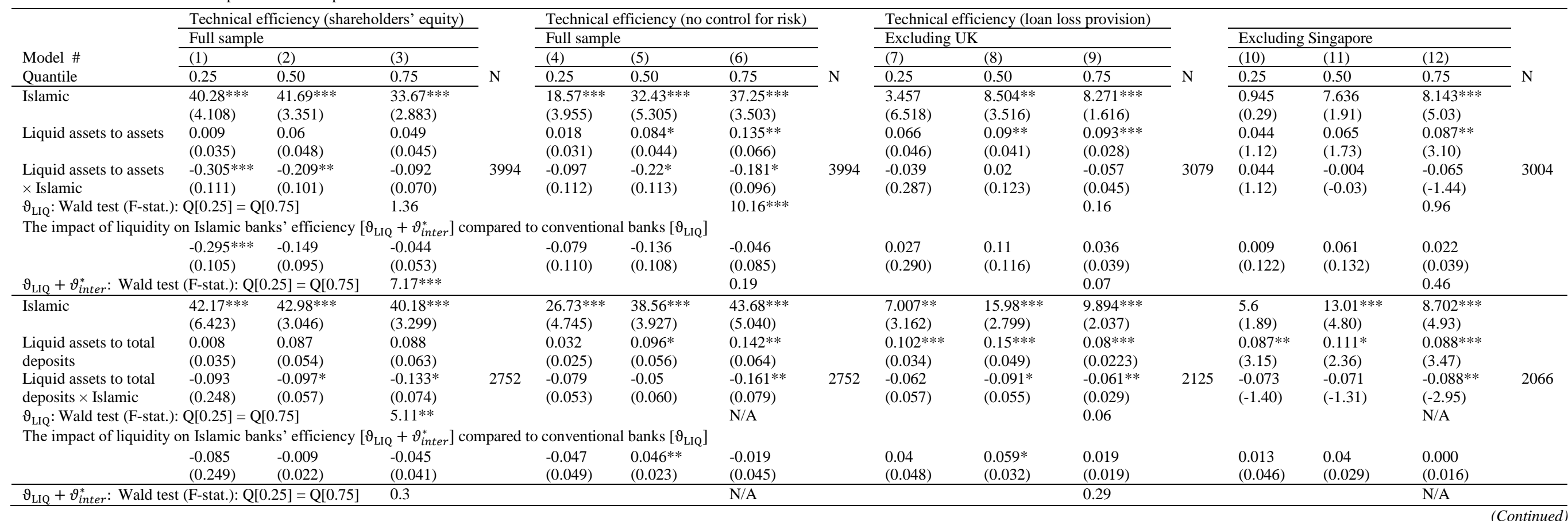

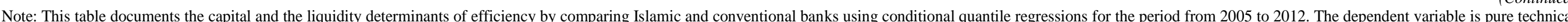



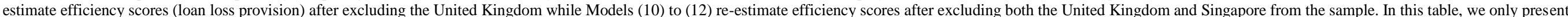


parentheses below their coefficient estimates. $*, * *$, and $* * *$ represent significance at the $10 \%, 5 \%$, and $1 \%$ level, respectively. 
Table 9

First difference regressions and other estimation techniques



Note: This table documents the capital and the liquidity determinants of efficiency by comparing Islamic and conventional banks using three different estimation techniques and standard errors. In Models (1) to (3) the dependent variable is the change in the bank efficiency scores. $\Delta$ indicates the firstdifference of the variable between two consecutive years. The estimation is based on conditional quantile regressions with standard errors clustered at the bank level. In the rest of the models the dependent variable is pure technical efficiency (loan loss provision). Model (4) uses truncated regressions and corrects for the heteroscedasticity of the standard errors using a White procedure. Models (5) and (6) use a random effect, GLS regression with bootstrapped standard errors (in Model (5)) and bank level clustered standard errors (in Model (6)). In this table, we only present the main independent variables to save space. BC, CC, CFE, and YFE are included but not reported. We present the 25th, 50th, and 75th quantile of the dependent variable. *, **, and *** represent significance at the $10 \%, 5 \%$, and $1 \%$ level, respectively. 
Table 10

More control variables and IV approach

\begin{tabular}{|c|c|c|c|c|c|c|c|c|c|c|c|c|c|c|c|c|}
\hline \multirow{4}{*}{$\begin{array}{l}\text { Model \# } \\
\text { Quantile }\end{array}$} & \multicolumn{7}{|c|}{ Conditional quantile regressions } & & \multicolumn{8}{|c|}{ IV approach } \\
\hline & \multicolumn{3}{|c|}{ More macro control } & \multirow[b]{3}{*}{$\mathrm{N}$} & \multicolumn{3}{|c|}{ One year lag } & \multirow[b]{3}{*}{$\mathrm{N}$} & \multicolumn{3}{|c|}{2 SLS } & \multirow{3}{*}{$\begin{array}{c}\text { Sargan } \\
\text { (p-value) }\end{array}$} & \multicolumn{3}{|c|}{ GMM } & \multirow{3}{*}{$\begin{array}{c}\text { Hansen's J } \\
\text { (p-value) }\end{array}$} \\
\hline & (1) & (2) & (3) & & (4) & (5) & (6) & & (7) & & & & (8) & & & \\
\hline & 0.25 & 0.50 & 0.75 & & 0.25 & 0.50 & 0.75 & & Coef. & $\mathrm{N}$ & $\mathrm{F}$ & & Coef. & $\mathrm{N}$ & $\mathrm{F}$ & \\
\hline Islamic & $\begin{array}{l}18.75^{* * * *} \\
(3.815)\end{array}$ & $\begin{array}{l}27.12 * * * \\
(6.340)\end{array}$ & $\begin{array}{l}28.14 * * * * \\
(5.272)\end{array}$ & & $\begin{array}{l}19.03 * * * \\
(3.644)\end{array}$ & $\begin{array}{l}22.76 * * * \\
(4.916)\end{array}$ & $\begin{array}{l}26.26 * * * * \\
(7.678)\end{array}$ & & $\begin{array}{l}11.52^{* * *} \\
(5.213)\end{array}$ & & & & $\begin{array}{l}11.36^{* * *} \\
(5.213)\end{array}$ & & & \\
\hline Tier1 capital $\left[\vartheta_{\mathrm{CAP}}\right]$ & $\begin{array}{l}0.059 \\
(0.073)\end{array}$ & $\begin{array}{l}0.265 \\
(0.172)\end{array}$ & $\begin{array}{l}0.255 \\
(0.172)\end{array}$ & & $\begin{array}{l}0.160^{*} \\
(0.084)\end{array}$ & $\begin{array}{l}0.239 * * \\
(0.097)\end{array}$ & $\begin{array}{l}0.391 \\
(0.356)\end{array}$ & & $\begin{array}{l}-0.327 \\
(0.316)\end{array}$ & & & & $\begin{array}{l}-0.327 \\
(0.316)\end{array}$ & & & \\
\hline $\begin{array}{l}\text { Tier1 capital }(-1) \\
\times \text { Islamic }\left[\vartheta_{\text {inter }}^{*}\right]\end{array}$ & $\begin{array}{l}-0.039 \\
(0.127)\end{array}$ & $\begin{array}{l}-0.068 \\
(0.217)\end{array}$ & $\begin{array}{l}-0.061 \\
(0.181)\end{array}$ & 1225 & $\begin{array}{l}-0.107 \\
(0.163)\end{array}$ & $\begin{array}{l}-0.016 \\
(0.197)\end{array}$ & $\begin{array}{l}-0.133 \\
(0.456)\end{array}$ & 1703 & $\begin{array}{l}0.372 \\
(0.276)\end{array}$ & 1759 & $27.89^{* * *}$ & 0.168 & $\begin{array}{l}0.38 \\
(0.276)\end{array}$ & 759 & $26.79 * * *$ & 0.182 \\
\hline \multicolumn{3}{|c|}{$\vartheta_{\text {CAP }}:$ Wald test (F-stat.): Q $[0.25]=\mathrm{Q}[0.75]$} & $3.13^{*}$ & & & & $3.67 *$ & & & & & & & & & \\
\hline \multicolumn{17}{|c|}{ The impact of capital on Islamic banks' efficiency $\left[\vartheta_{\mathrm{CAP}}+\vartheta_{\text {inter }}^{*}\right]$ compared to conventional banks $\left[\vartheta_{\mathrm{CAP}}\right]$} \\
\hline & $\begin{array}{l}0.02 \\
(0.093)\end{array}$ & $\begin{array}{l}0.167 \\
(0.173)\end{array}$ & $\begin{array}{l}0.193 * * * \\
(0.056)\end{array}$ & & $\begin{array}{l}0.052 \\
(0.145)\end{array}$ & $\begin{array}{l}0.224 \\
(0.175)\end{array}$ & $\begin{array}{l}0.258 \\
(0.291)\end{array}$ & & $\begin{array}{l}0.045 \\
(0.090)\end{array}$ & & & & $\begin{array}{l}0.053 \\
(0.089)\end{array}$ & & & \\
\hline \multicolumn{3}{|c|}{$\vartheta_{\mathrm{CAP}}+\vartheta_{\text {inter }}^{*}:$ Wald test (F-stat.): $\mathrm{Q}[0.25]=\mathrm{Q}[0.75]$} & 1.33 & & & & 2.33 & & & & & & & & & \\
\hline Islamic & $\begin{array}{l}18.23 * * * \\
(4.463)\end{array}$ & $\begin{array}{l}24.9^{* *} \\
(10.48)\end{array}$ & $\begin{array}{l}25.10 * * * \\
(4.919)\end{array}$ & & $\begin{array}{l}16.92 * * * \\
(4.009)\end{array}$ & $\begin{array}{l}22.47 * * * \\
(5.868)\end{array}$ & $\begin{array}{l}26.96^{* * * *} \\
(6.438)\end{array}$ & & $\begin{array}{l}17.19^{* * * *} \\
(4.940)\end{array}$ & & & & $\begin{array}{l}17.4^{* * * *} \\
(4.932)\end{array}$ & & & \\
\hline Capital adequacy $\left[\vartheta_{\text {CAP }}\right]$ & $\begin{array}{l}0.026 \\
(0.062)\end{array}$ & $\begin{array}{l}0.03 \\
(0.140)\end{array}$ & $\begin{array}{l}0.149 \\
(0.159)\end{array}$ & & $\begin{array}{l}0.127 \\
(0.081)\end{array}$ & $\begin{array}{l}0.249 * * * \\
(0.086)\end{array}$ & $\begin{array}{l}0.4 * * * \\
(0.097)\end{array}$ & & $\begin{array}{l}0.067 \\
(0.257)\end{array}$ & & & & $\begin{array}{l}0.074 \\
(0.256)\end{array}$ & & & \\
\hline \multirow{3}{*}{$\begin{array}{l}\text { Capital adequacy (-1) } \\
\times \text { Islamic }\left[\vartheta_{\text {inter }}^{*}\right] \\
\vartheta_{\text {CAP }}: \text { Wald test (F-stat.): Q }[0.2 \\
\text { The impact of capital on Islami }\end{array}$} & $\begin{array}{l}-0.03 \\
(0.156) \\
=Q[0.75]\end{array}$ & $\begin{array}{l}0.071 \\
(0.466)\end{array}$ & $\begin{array}{l}0.022 \\
(0.164) \\
1.22\end{array}$ & 1424 & $\begin{array}{l}-0.019 \\
(0.194)\end{array}$ & $\begin{array}{l}0.036 \\
(0.239)\end{array}$ & $\begin{array}{l}-0.155 \\
(0.313) \\
11.83 * * *\end{array}$ & 1981 & $\begin{array}{l}0.042 \\
(0.231)\end{array}$ & 2199 & $27.37 * * *$ & 0.333 & $\begin{array}{l}0.03 \\
(0.230)\end{array}$ & 2199 & $27.37 * * *$ & 0.324 \\
\hline & banks' effic & ency $\left[\vartheta_{\text {CAP }}+r-1-1\right.$ & *inter] compa & to con & entional banl & {$\left[\vartheta_{\mathrm{CAP}}\right]$} & & & & & & & & & & \\
\hline & $\begin{array}{l}-0.004 \\
(0.143)\end{array}$ & $\begin{array}{l}0.101 \\
(0.463)\end{array}$ & $\begin{array}{l}0.17 * * * \\
(0.061)\end{array}$ & & $\begin{array}{l}0.108 \\
(0.174)\end{array}$ & $\begin{array}{l}0.285 \\
(0.228)\end{array}$ & $\begin{array}{l}0.246 \\
(0.293)\end{array}$ & & $\begin{array}{l}0.109 \\
(0.076)\end{array}$ & & & & $\begin{array}{l}0.107 \\
(0.076)\end{array}$ & & & \\
\hline \multicolumn{3}{|c|}{$\vartheta_{\text {CAP }}+\vartheta_{\text {inter }}^{*}:$ Wald test (F-stat.): $\mathrm{Q}[0.25]=\mathrm{Q}[0.75]$} & 1.07 & & & & 0.04 & & & & & & & & & \\
\hline Islamic & $\begin{array}{l}17.52^{* * * *} \\
(3.493)\end{array}$ & $\begin{array}{l}34.82 * * * \\
(5.060)\end{array}$ & $\begin{array}{l}34.87 * * * \\
(5.274)\end{array}$ & & $\begin{array}{l}19.52 * * * \\
(3.308)\end{array}$ & $\begin{array}{l}29.05 * * * \\
(3.826)\end{array}$ & $\begin{array}{l}33.55 * * * \\
(3.399)\end{array}$ & & $\begin{array}{l}30.46^{* * * *} \\
(3.195)\end{array}$ & & & & $\begin{array}{l}30.74 * * * \\
(3.194)\end{array}$ & & & \\
\hline Shareholders' equity $\left[\vartheta_{\text {CAP }}\right]$ & $\begin{array}{l}0.589 * * * \\
(0.128)\end{array}$ & $\begin{array}{l}0.871 * * * \\
(0.122)\end{array}$ & $\begin{array}{l}1.006 * * * \\
(0.176)\end{array}$ & 1918 & $\begin{array}{l}0.556^{* * * *} \\
(0.106)\end{array}$ & $\begin{array}{l}0.754 * * * \\
(0.094)\end{array}$ & $\begin{array}{l}0.944 * * * \\
(0.148)\end{array}$ & & $\begin{array}{l}1.258 * * * \\
(0.235)\end{array}$ & & & & $\begin{array}{l}1.286 * * * \\
(0.235)\end{array}$ & & & \\
\hline \multirow{2}{*}{$\begin{array}{l}\text { Shareholders' equity }(-1) \\
\times \text { Islamic }\left[\vartheta_{\text {inter }}^{*}\right] \\
\vartheta_{\text {CAP }}: \text { Wald test (F-stat.): Q[0.2 }\end{array}$} & $\begin{array}{l}-0.077 \\
(0.162)\end{array}$ & $\begin{array}{l}-0.593^{* * * *} \\
(0.147)\end{array}$ & $\begin{array}{l}-0.79 * * * \\
(0.262)\end{array}$ & & $\begin{array}{l}-0.303 \\
(0.191)\end{array}$ & $\begin{array}{l}-0.454 * * * \\
(0.109)\end{array}$ & $\begin{array}{l}-0.763^{* * * *} \\
(0.143)\end{array}$ & 2727 & $\begin{array}{l}-0.81 * * * \\
(0.214)\end{array}$ & 3106 & $61.71 * * *$ & 0.125 & $\begin{array}{l}-0.83 * * * \\
(0.214)\end{array}$ & 3106 & $61.71 * * *$ & 0.111 \\
\hline & ]$=Q[0.75]$ & & $12.06^{* * * *}$ & & & & $10.14 * * *$ & & & & & & & & & \\
\hline \multicolumn{17}{|c|}{ The impact of capital on Islamic banks' efficiency $\left[\vartheta_{\mathrm{CAP}}+\vartheta_{\text {inter }}^{*}\right]$ compared to conventional banks $\left[\vartheta_{\mathrm{CAP}}\right]$} \\
\hline & $\begin{array}{l}0.513^{* * * *} \\
(0.091)\end{array}$ & $\begin{array}{l}0.278^{* * * *} \\
(0.080)\end{array}$ & $\begin{array}{l}0.216 \\
(0.226)\end{array}$ & & $\begin{array}{l}0.253 \\
(0.161)\end{array}$ & $\begin{array}{l}0.3^{* * * *} \\
(0.062)\end{array}$ & $\begin{array}{l}0.181 * * * \\
(0.058)\end{array}$ & & $\begin{array}{l}0.445^{* * * *} \\
(0.082)\end{array}$ & & & & $\begin{array}{l}0.451 * * * \\
(0.083)\end{array}$ & & & \\
\hline$\vartheta_{\mathrm{CAP}}+\vartheta_{\text {inter }}^{*}:$ Wald test (F-sta & $\mathrm{Q}: \mathrm{Q}[0.25]=$ & $\underline{\mathrm{Q}}[0.75]$ & $3.94 * *$ & & & & $8.13 * * *$ & & & & & & & & & \\
\hline Islamic & $\begin{array}{l}19.68 * * * \\
(4.638)\end{array}$ & $\begin{array}{l}30.34 * * * \\
(5.089)\end{array}$ & $\begin{array}{l}31.07 * * * * \\
(3.794)\end{array}$ & & $\begin{array}{l}17.39 * * * \\
(4.208)\end{array}$ & $\begin{array}{l}26.16 * * * \\
(3.577)\end{array}$ & $\begin{array}{l}25.23 * * * \\
(3.114)\end{array}$ & & $\begin{array}{l}38.72 * * * \\
(2.745)\end{array}$ & & & & $\begin{array}{l}38.9 * * * \\
(2.757)\end{array}$ & & & \\
\hline Maturity match $\left[\vartheta_{\mathrm{LIQ}}\right]$ & $\begin{array}{l}0.123^{* * *} \\
(0.026)\end{array}$ & $\begin{array}{l}0.157^{* * *} \\
(0.030)\end{array}$ & $\begin{array}{l}0.223 * * * \\
(0.040)\end{array}$ & & $\begin{array}{l}0.117 * * * \\
(0.015)\end{array}$ & $\begin{array}{l}0.14 * * * \\
(0.025)\end{array}$ & $\begin{array}{l}0.13^{* * * *} \\
(0.012)\end{array}$ & & $\begin{array}{l}0.431^{* * *} \\
(0.061)\end{array}$ & & & & $\begin{array}{l}0.436^{* * * *} \\
(0.061)\end{array}$ & & & \\
\hline $\begin{array}{l}\text { Maturity match }(-1) \\
\times \text { Islamic }\left[\vartheta_{\text {inter }}^{*}\right]\end{array}$ & $\begin{array}{l}-0.071 * * * \\
(0.027)\end{array}$ & $\begin{array}{l}-0.116^{* * * *} \\
(0.031)\end{array}$ & $\begin{array}{l}-0.199 * * * \\
(0.043)\end{array}$ & 1916 & $\begin{array}{l}-0.067 \\
(0.095)\end{array}$ & $\begin{array}{l}-0.079 * * * \\
(0.026)\end{array}$ & $\begin{array}{l}-0.074 * * * \\
(0.0147)\end{array}$ & 2717 & $\begin{array}{l}-0.38 * * * \\
(0.060)\end{array}$ & 3368 & $30.45^{* * *}$ & 0.336 & $\begin{array}{l}-0.39 * * * \\
(0.061)\end{array}$ & 3368 & $30.45^{* * *}$ & 0.364 \\
\hline$\vartheta_{\text {CAP }}:$ Wald test (F-stat.): Q $[0.2$ & $\mathrm{E}=\mathrm{Q}[0.75]$ & & $9.93 * * *$ & & & & 0.21 & & & & & & & & & \\
\hline The impact of liquidity on Islar & iic banks' ef & ciency $\left[\vartheta_{\text {LIQ }}\right.$ & $\left.\vartheta_{\text {inter }}^{*}\right]$ comp & d to $c$ & yentional bat & $\mathrm{ss}\left[\vartheta_{\mathrm{LIO}}\right]$ & & & & & & & & & & \\
\hline & $\begin{array}{l}0.051 * * * \\
(0.008)\end{array}$ & $\begin{array}{l}0.041 * * * * \\
(0.009)\end{array}$ & $\begin{array}{l}0.024 \\
(0.018)\end{array}$ & & $\begin{array}{l}0.05 \\
(0.095)\end{array}$ & $\begin{array}{l}0.062 * * * \\
(0.015)\end{array}$ & $\begin{array}{l}0.056 * * * \\
(0.008)\end{array}$ & & $\begin{array}{l}0.048 * * * \\
(0.008)\end{array}$ & & & & $\begin{array}{l}0.048 * * * \\
(0.008)\end{array}$ & & & \\
\hline$\vartheta_{\mathrm{LIQ}}+\vartheta_{\text {inter }}^{*}:$ Wald test (F-sta & : $\mathrm{Q}[0.25]=$ & $\mathrm{Q}[0.75]$ & 2.04 & & & & 0.22 & & & & & & & & & \\
\hline Islamic & $\begin{array}{l}32.57 * * * \\
(8.551)\end{array}$ & $\begin{array}{l}36.22 * * * \\
(5.856)\end{array}$ & $\begin{array}{l}27.62 * * * \\
(4.185)\end{array}$ & & $\begin{array}{l}18.37 * * * \\
(3.849)\end{array}$ & $\begin{array}{l}23.62 * * * \\
(5.378)\end{array}$ & $\begin{array}{l}24.97 * * * \\
(4.078)\end{array}$ & & $\begin{array}{l}208.4 * * * \\
(61.75)\end{array}$ & & & & $\begin{array}{l}209.7 * * * \\
(62.01)\end{array}$ & & & \\
\hline Liquid assets to assets $\left[\vartheta_{\mathrm{LIQ}}\right]$ & $\begin{array}{l}0.057 \\
(0.050)\end{array}$ & $\begin{array}{l}0.084 \\
(0.066)\end{array}$ & $\begin{array}{l}0.162^{*} \\
(0.090)\end{array}$ & & $\begin{array}{l}0.127 * * * \\
(0.040)\end{array}$ & $\begin{array}{l}0.133 * * * \\
(0.050)\end{array}$ & $\begin{array}{l}0.097 \\
(0.064)\end{array}$ & & $\begin{array}{l}6.613 * * * \\
(2.188)\end{array}$ & & & & $\begin{array}{l}6.657 * * * \\
(2.197)\end{array}$ & & & \\
\hline Liquid assets to assets (-1) & $-0.544 *$ & $-0.349^{*}$ & -0.178 & 1918 & -0.1 & 0.026 & -0.138 & 2722 & $-6.18 * * *$ & 3370 & $4.59 * *$ & 0.733 & $-6.23 * * *$ & 3370 & $4.6 * * *$ & 0.757 \\
\hline
\end{tabular}


The impact of liquidity on Islamic banks' efficie

entional banks $\left[\vartheta_{\mathrm{LIQ}}\right]$

$\begin{array}{ccccc} & & & & \\ 0.486^{*} & -0.265 & -0.016 & 0.026 & 0.159\end{array}$

$\begin{array}{lllll}-0.486 & -0.265 & -0.016 & 0.026 & 0.159 \\ (0.273) & (0.191) & (0.059) & (0.107) & (0.129)\end{array}$

$0.129)$

$(0.078)$ 0.45

Islamic $36.78^{* * *} \quad 38.52 * *$

(5.830)

Liquid assets to total deposits

$28.97 * * * \quad 35.86^{* * * *}$

$30.89^{* * * *}$

[ $\left.\vartheta_{\text {LIQ }}\right]$

$0.11 * *$

$\begin{array}{ll}28.97 * & 35.86 \\ (4.651) & (3.650)\end{array}$

$30.89^{* *}$
$(5.875)$
$0.125 * *$

0.428

$0.43^{3 *}$

(1) $\times$ Islases $\quad-0.308$

$(0.053)$

$0.133 *$

$(3.650)$
$0.146 * * *$

$(0.034) \quad(0.047)$

$0.125^{*}$

$53.49 * * *$
$(4.381)$

$-0.144$

$1437-0.088 * * \quad-0.105 * *$

$-0.133 * *$

0.14

$\begin{array}{lll}(0.040) & (0.049) \quad(0.053)\end{array}$

0.48

The impact of liquidity on Islamic banks' efficiency $\left[\vartheta_{\mathrm{LIQ}}+\vartheta_{\text {inter }}^{*}\right]$ compared to conventional banks $\left[\vartheta_{\mathrm{LIQ}}\right]$

$\begin{array}{lllll}-0.201 & 0.006 & -0.016 & 0.046 & 0.042 \\ (0.421) & (0.075) & (0.035) & (0.023) & (0.023)\end{array}$

$-0.008$

0.15

$(0.023) \quad(0.023)$

$(0.024)$

0.16

$(4.381)$
$0.761 * * *$

$(0.110)$

$1927-0.72^{* * * *}$

(1)

$(0.038)$

0.16

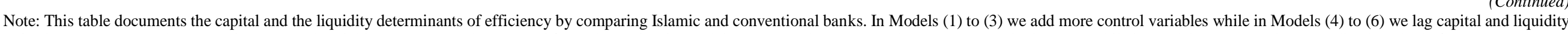

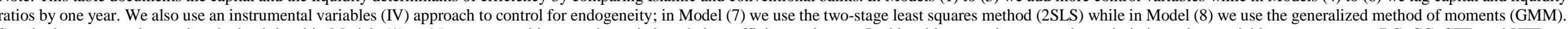

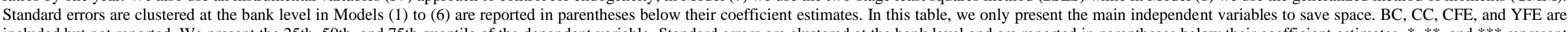

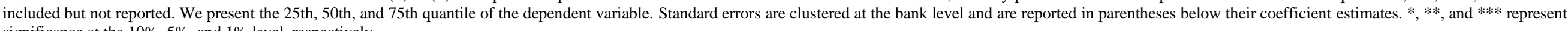
significance at the $10 \%, 5 \%$, and $1 \%$ level, respectively. 
Table 11

The effect of higher capital and liquidity on bank efficiency using a common efficiency frontier

\begin{tabular}{|c|c|c|c|c|c|c|c|c|c|c|c|c|}
\hline & \multicolumn{12}{|c|}{ Common efficiency frontier (loan loss provision) } \\
\hline & \multicolumn{3}{|l|}{ Full sample } & \multirow[b]{3}{*}{$\mathrm{N}$} & \multicolumn{3}{|c|}{ Excluding UK } & \multirow[b]{3}{*}{$\mathrm{N}$} & \multicolumn{3}{|c|}{ Excluding Singapore } & \multirow[b]{3}{*}{$\mathrm{N}$} \\
\hline Model \# & (1) & (2) & (3) & & (7) & (8) & (9) & & (10) & (11) & (12) & \\
\hline Quantile & 0.25 & 0.50 & 0.75 & & 0.25 & 0.50 & 0.75 & & 0.25 & 0.50 & 0.75 & \\
\hline Islamic & $\begin{array}{l}-5.19 * * \\
(2.476)\end{array}$ & $\begin{array}{l}-1.827 \\
(4.188)\end{array}$ & $\begin{array}{l}3.112 \\
(7.800)\end{array}$ & & $\begin{array}{l}-6.088^{*} \\
(-2.02)\end{array}$ & $\begin{array}{l}-3.7 \\
(-0.95)\end{array}$ & $\begin{array}{l}3.444 \\
(0.50)\end{array}$ & & $\begin{array}{l}-5.402 * * \\
(-2.58)\end{array}$ & $\begin{array}{l}-4.240 \\
(-1.22)\end{array}$ & $\begin{array}{l}3.206 \\
(0.33)\end{array}$ & \\
\hline Tier1 capital $\left[\vartheta_{\mathrm{CAP}}\right]$ & $\begin{array}{l}0.134 \\
(0.082)\end{array}$ & $\begin{array}{l}0.317 * * * \\
(0.096)\end{array}$ & $\begin{array}{l}0.405 * * * \\
(0.144)\end{array}$ & & $\begin{array}{l}0.109 \\
(1.13)\end{array}$ & $\begin{array}{l}0.274 * * \\
(2.66)\end{array}$ & $\begin{array}{l}0.473^{*} \\
(2.55)\end{array}$ & & $\begin{array}{l}0.159^{*} \\
(2.03)\end{array}$ & $\begin{array}{l}0.313^{* * * *} \\
(3.61)\end{array}$ & $\begin{array}{l}0.409^{* *} \\
(2.83)\end{array}$ & \\
\hline $\begin{array}{l}\text { Tier1 capital } \times \text { Islamic } \\
{\left[\vartheta_{\text {inter }}^{*}\right]}\end{array}$ & $\begin{array}{l}0.126 \\
(0.111)\end{array}$ & $\begin{array}{l}-0.043 \\
(0.242)\end{array}$ & $\begin{array}{l}-0.005 \\
(0.160)\end{array}$ & 2071 & $\begin{array}{l}0.149 \\
(0.98)\end{array}$ & $\begin{array}{l}0.055 \\
(0.25)\end{array}$ & $\begin{array}{l}0.029 \\
(0.19)\end{array}$ & 1862 & $\begin{array}{l}0.13 \\
(1.36)\end{array}$ & $\begin{array}{l}0.079 \\
(0.43)\end{array}$ & $\begin{array}{l}0.058 \\
(0.14)\end{array}$ & 1812 \\
\hline \multirow{2}{*}{\multicolumn{7}{|c|}{$\begin{array}{l}\vartheta_{\text {CAP: Wald test (p-value): }[0.25]=Q[0.75]} 2.14 \\
\text { The impact of higher capital on Islamic banks' efficiency }\left[\beta_{C A P}+\beta_{\text {inter }}\right] \text { compared to conventional banks }\left[\beta_{C A P}\right]\end{array}$}} & N/A & & & & N/A & \\
\hline & & \multicolumn{11}{|c|}{ The impact of higher capital on Islamic banks' efficiency $\left[\beta_{\mathrm{CAP}}+\beta_{\text {inter }}\right]$ compared to conventional banks [ $\left.\beta_{\mathrm{CAP}}\right]$} \\
\hline & $\begin{array}{l}0.259 * * * \\
(0.067)\end{array}$ & $\begin{array}{l}0.274 \\
(0.222)\end{array}$ & $\begin{array}{l}0.4 * * * * \\
(0.075)\end{array}$ & & $\begin{array}{l}0.257 * * \\
(0.126)\end{array}$ & $\begin{array}{l}0.328 \\
(0.203)\end{array}$ & $\begin{array}{l}0.402 * * * \\
(0.067)\end{array}$ & & $\begin{array}{l}0.289 * * * \\
(0.061)\end{array}$ & $\begin{array}{l}0.392 * * \\
(0.179)\end{array}$ & $\begin{array}{l}0.467 \\
(0.395)\end{array}$ & \\
\hline \multicolumn{3}{|c|}{$\vartheta_{\text {CAP }}+\vartheta_{\text {inter }}^{*}:$ Wald test (F-stat.): Q[0.25] $=\mathrm{Q}[0.75]$} & 2.13 & & & & N/A & & & & N/A & \\
\hline Islamic & $\begin{array}{l}-3.703 \\
(3.012)\end{array}$ & $\begin{array}{l}0.149 \\
(2.729)\end{array}$ & $\begin{array}{l}5.651 \\
(5.361)\end{array}$ & & $\begin{array}{l}-4.336^{*} \\
(-2.02)\end{array}$ & $\begin{array}{l}-1.979 \\
(-0.50)\end{array}$ & $\begin{array}{l}5.226 \\
(0.88)\end{array}$ & & $\begin{array}{l}-4.122 \\
(-1.88)\end{array}$ & $\begin{array}{l}-2.106 \\
(-0.46)\end{array}$ & $\begin{array}{l}4.776 \\
(0.63)\end{array}$ & \\
\hline Capital adequacy $\left[\vartheta_{\text {CAP }}\right]$ & $\begin{array}{l}0.163^{*} \\
(0.084)\end{array}$ & $\begin{array}{l}0.308 * * * \\
(0.073)\end{array}$ & $\begin{array}{l}0.482 * * * \\
(0.103)\end{array}$ & & $\begin{array}{l}0.135^{*} \\
(2.02)\end{array}$ & $\begin{array}{l}0.285 * * * \\
(3.78)\end{array}$ & $\begin{array}{l}0.465^{* * * *} \\
(3.68)\end{array}$ & & $\begin{array}{l}0.188^{*} \\
(2.26)\end{array}$ & $\begin{array}{l}0.312 * * * \\
(3.64)\end{array}$ & $\begin{array}{l}0.48 * * * \\
(5.07)\end{array}$ & \\
\hline \multirow{2}{*}{$\begin{array}{l}\text { Capital adequacy } \times \text { Islamic } \\
{\left[\vartheta_{\text {inter }}^{*}\right]} \\
\vartheta_{\text {CAP }}: \text { Wald test }(\mathrm{p} \text {-value }): \mathrm{Q}[\mathrm{C}\end{array}$} & $\begin{array}{l}0.091 \\
(0.145)\end{array}$ & $\begin{array}{l}-0.082 \\
(0.125)\end{array}$ & $\begin{array}{l}-0.071 \\
(0.121)\end{array}$ & 2550 & $\begin{array}{l}0.112 \\
(1.23)\end{array}$ & $\begin{array}{l}0.011 \\
(0.05)\end{array}$ & $\begin{array}{l}-0.062 \\
(-0.43)\end{array}$ & 2315 & $\begin{array}{l}0.075 \\
(0.72)\end{array}$ & $\begin{array}{l}0.039 \\
(0.16)\end{array}$ & $\begin{array}{l}-0.019 \\
(-0.07)\end{array}$ & 2265 \\
\hline & $.25]=\mathrm{Q}[0.7$ & & $15.96^{* * * *}$ & & & & N/A & & & & N/A & \\
\hline \multicolumn{13}{|c|}{ The impact of higher capital on Islamic banks' efficiency $\left[\beta_{\mathrm{CAP}}+\beta_{\text {inter }}\right]$ compared to conventional banks $\left[\beta_{\mathrm{CAP}}\right]$} \\
\hline & $0.254 * *$ & $0.226 * *$ & $0.411 * * *$ & & $0.247 * * *$ & 0.296 & $0.402 * * *$ & & $0.263 * * *$ & 0.352 & $0.462 *$ & \\
\hline & $(0.114)$ & $(0.101)$ & $(0.066)$ & & $(0.054)$ & $(0.195)$ & $(0.073)$ & & $(0.061)$ & $(0.242)$ & $(0.244)$ & \\
\hline \multicolumn{3}{|c|}{$\vartheta_{\mathrm{CAP}}+\vartheta_{\text {inter }}^{*}:$ Wald test (F-stat.): Q[0.25] $=\mathrm{Q}[0.75$} & 1.67 & & & & N/A & & & & N/A & \\
\hline Islamic & $\begin{array}{l}-3.117 \\
(3.323)\end{array}$ & $\begin{array}{l}0.541 \\
(1.859)\end{array}$ & $\begin{array}{l}7.904 \\
(5.702)\end{array}$ & & $\begin{array}{l}-1.843 \\
(-0.54)\end{array}$ & $\begin{array}{l}-0.616 \\
(-0.28)\end{array}$ & $\begin{array}{l}6.72 \\
(1.16)\end{array}$ & & $\begin{array}{l}-4.394 \\
(-1.93)\end{array}$ & $\begin{array}{l}-1.408 \\
(-0.63)\end{array}$ & $\begin{array}{l}5.533 \\
(1.36)\end{array}$ & \\
\hline Shareholders' equity $\left[\vartheta_{\mathrm{CAP}}\right]$ & $\begin{array}{l}0.534 * * * \\
(0.080)\end{array}$ & $\begin{array}{l}0.876 * * * \\
(0.068)\end{array}$ & $\begin{array}{l}1.01 * * * \\
(0.111)\end{array}$ & & $\begin{array}{l}0.593 * * * \\
(6.59)\end{array}$ & $\begin{array}{l}0.786 * * * \\
(7.84)\end{array}$ & $\begin{array}{l}0.976^{* * * *} \\
(5.90)\end{array}$ & & $\begin{array}{l}0.559 * * * \\
(6.55)\end{array}$ & $\begin{array}{l}0.802 * * * * \\
(8.52)\end{array}$ & $\begin{array}{l}1.015^{* * * *} \\
(5.43)\end{array}$ & \\
\hline \multirow{3}{*}{$\begin{array}{l}\text { Shareholders' equity } \times \\
\text { Islamic }\left[\vartheta_{\text {inter }}^{*}\right] \\
\vartheta_{\text {CAP }}: \text { Wald test (p-value): } Q[C\end{array}$} & 0.11 & -0.071 & -0.255 & 3583 & -0.03 & -0.066 & -0.263 & 3036 & 0.151 & 0.009 & -0.157 & 2961 \\
\hline & $(0.267)$ & $(0.087)$ & $(0.283)$ & & $(-0.11)$ & $(-0.52)$ & $(-0.73)$ & & $(1.28)$ & $(0.07)$ & $(-0.63)$ & \\
\hline & $.25]=\mathrm{Q}[0.7$ & & $14.61 * * *$ & & & & $9.84 * * *$ & & & & $12.88^{* * * *}$ & \\
\hline \multicolumn{13}{|c|}{ The impact of higher capital on Islamic banks' efficiency $\left[\beta_{\mathrm{CAP}}+\beta_{\text {inter }}\right]$ compared to conventional banks $\left[\beta_{\mathrm{CAP}}\right]$} \\
\hline \multirow{3}{*}{\multicolumn{2}{|c|}{$\begin{aligned} & 0.643^{* *} \\
& (0.261) \\
\vartheta_{\mathrm{CAP}}+\vartheta_{\text {inter }}^{*}: \text { Wald test (F-stat.): } & \mathrm{Q}[0.25]=\end{aligned}$}} & $0.805^{* * * *}$ & $0.755 * * *$ & & $0.562 * *$ & $0.72 * * * *$ & $0.714 * *$ & & $0.71 * * *$ & $0.811 * * *$ & $0.858 * * *$ & \\
\hline & & $(0.061)$ & $(0.267)$ & & $(0.258)$ & $(0.095)$ & $(0.347)$ & & $(0.078)$ & $(0.087)$ & $(0.176)$ & \\
\hline & & $\mathrm{Q}[0.75]$ & 0.11 & & & & 0.61 & & & & 0.64 & \\
\hline Islamic & $\begin{array}{l}1.16 \\
(1.422)\end{array}$ & $\begin{array}{l}0.777 \\
(2.938)\end{array}$ & $\begin{array}{l}9.25^{*} \\
(4.810)\end{array}$ & & $\begin{array}{l}-1.304 \\
(-0.80)\end{array}$ & $\begin{array}{l}0.043 \\
(0.02)\end{array}$ & $\begin{array}{l}8.081 \\
(1.28)\end{array}$ & & $\begin{array}{l}-1.124 \\
(-0.67)\end{array}$ & $\begin{array}{l}0.293 \\
(0.13)\end{array}$ & $\begin{array}{l}8.923 \\
(1.24)\end{array}$ & \\
\hline Maturity match $\left[\vartheta_{\mathrm{LIQ}}\right]$ & $\begin{array}{l}0.128^{* * *} \\
(0.011)\end{array}$ & $\begin{array}{l}0.158 * * * \\
(0.015)\end{array}$ & $\begin{array}{l}0.167 * * * \\
(0.026)\end{array}$ & & $\begin{array}{l}0.135^{* * * *} \\
(11.26)\end{array}$ & $\begin{array}{l}0.162 * * * \\
(13.62)\end{array}$ & $\begin{array}{l}0.199 * * * \\
(3.38)\end{array}$ & & $\begin{array}{l}0.138 * * * \\
(12.10)\end{array}$ & $\begin{array}{l}0.165^{* * * *} \\
(11.37)\end{array}$ & $\begin{array}{l}0.219 * * * \\
(3.97)\end{array}$ & \\
\hline $\begin{array}{l}\text { Maturity match } \times \text { Islamic } \\
{\left[\vartheta_{\text {inter }}^{*}\right]}\end{array}$ & $\begin{array}{l}-0.045^{* * * *} \\
(0.012)\end{array}$ & $\begin{array}{l}-0.049 \\
(0.033)\end{array}$ & $\begin{array}{l}-0.066^{* *} \\
(0.031)\end{array}$ & 3576 & $\begin{array}{l}-0.052 * * * \\
(-3.93)\end{array}$ & $\begin{array}{l}-0.064 * * * \\
(-4.21)\end{array}$ & $\begin{array}{l}-0.116 \\
(-1.94)\end{array}$ & 3035 & $\begin{array}{l}-0.05 * * * \\
(-4.31)\end{array}$ & $\begin{array}{l}-0.067 * * * \\
(-3.83)\end{array}$ & $\begin{array}{l}-0.13 \\
(-1.94)\end{array}$ & 2961 \\
\hline$\vartheta_{\text {LIQ: }}:$ Wald test (p-value): $\mathrm{Q}[0.2$ & $25]=Q[0.75]$ & & 0.34 & & & & $3.15^{*}$ & & & & $6.09 * *$ & \\
\hline The impact of higher liquidity & on Islamic ban & ks' efficienc & $\beta_{\text {LIQ }}+\beta_{\text {inte }}$ & ompare & to conventic & 1 banks $\left[\beta_{\mathrm{LIQ}}\right.$ & & & & & & \\
\hline & $\begin{array}{l}0.083 * * * \\
(0.006)\end{array}$ & $\begin{array}{l}0.108^{* * *} \\
(0.029)\end{array}$ & $\begin{array}{l}0.081 * * * \\
(0.016)\end{array}$ & & $\begin{array}{l}0.083 * * * \\
(0.006)\end{array}$ & $\begin{array}{l}0.098 * * * * \\
(0.010)\end{array}$ & $\begin{array}{l}0.083 * * * \\
(0.021)\end{array}$ & & $\begin{array}{l}0.082 * * * \\
(0.006)\end{array}$ & $\begin{array}{l}0.098^{* * * *} \\
(0.010)\end{array}$ & $\begin{array}{l}0.088 \\
(0.056)\end{array}$ & \\
\hline$\vartheta_{\text {LIQ }}+\vartheta_{\text {inter }}^{*}:$ Wald test (F-sta & $\mathrm{Q}[0.25]=$ & $\mathrm{Q}[0.75]$ & 0.03 & & & & 0.01 & & & & 0.1 & \\
\hline Islamic & $\begin{array}{l}-0.366 \\
(2.902)\end{array}$ & $\begin{array}{l}1.416 \\
(4.487)\end{array}$ & $\begin{array}{l}21.15 * * \\
(8.982)\end{array}$ & & $\begin{array}{l}0.622 \\
(0.17)\end{array}$ & $\begin{array}{l}3.741 \\
(0.62)\end{array}$ & $\begin{array}{l}20.21 \\
(1.87)\end{array}$ & & $\begin{array}{l}0.399 \\
(0.11)\end{array}$ & $\begin{array}{l}4.424 \\
(0.84)\end{array}$ & $\begin{array}{l}19.89^{*} \\
(2.08)\end{array}$ & \\
\hline Liquid assets to assets $\left[\vartheta_{\mathrm{LIQ}}\right]$ & $\begin{array}{l}0.055 \\
(0.038)\end{array}$ & $\begin{array}{l}0.124 * * \\
(0.050)\end{array}$ & $\begin{array}{l}0.126^{*} \\
(0.064)\end{array}$ & & $\begin{array}{l}0.025 \\
(0.56)\end{array}$ & $\begin{array}{l}0.111^{*} \\
(2.40)\end{array}$ & $\begin{array}{l}0.168 * * \\
(2.72)\end{array}$ & & $\begin{array}{l}0.014 \\
(0.33)\end{array}$ & $\begin{array}{l}0.12 * * \\
(2.67)\end{array}$ & $\begin{array}{l}0.177 * * \\
(2.96)\end{array}$ & \\
\hline
\end{tabular}




\begin{tabular}{|c|c|c|c|c|c|c|c|c|c|c|c|c|}
\hline \multicolumn{2}{|c|}{$\begin{array}{lc}\text { Liquid assets to assets } \times & -0.074 \\
\text { Islamic }\left[\vartheta_{\text {inter }}^{*}\right] & (0.098) \\
\vartheta_{\text {LIQ }}: \text { Wald test (p-value): } \mathrm{Q}[0.25]=\mathrm{Q}[0.75\end{array}$} & $\begin{array}{l}-0.06 \\
(0.132)\end{array}$ & $\begin{array}{l}-0.43^{*} \\
(0.246) \\
0.15\end{array}$ & 3577 & $\begin{array}{l}-0.151 \\
(-1.33)\end{array}$ & $\begin{array}{l}-0.195 \\
(-1.21)\end{array}$ & $\begin{array}{l}-0.508 \\
(-1.93) \\
9.37 * * *\end{array}$ & 3036 & $\begin{array}{l}-0.148 \\
(-1.45)\end{array}$ & $\begin{array}{l}-0.205 \\
(-1.37)\end{array}$ & $\begin{array}{l}-0.505^{*} \\
(-2.25) \\
10.1 * * *\end{array}$ & 2961 \\
\hline \multicolumn{13}{|c|}{ The impact of higher liquidity on Islamic banks' efficiency $\left[\beta_{\mathrm{LIQ}}+\beta_{\text {inter }}\right]$ compared to conventional banks $\left[\beta_{\mathrm{LIQ}}\right]$} \\
\hline$\vartheta_{\mathrm{LIO}}+\vartheta_{\text {inter }}^{*}:$ Wald test $(\mathrm{F}$ & $\begin{array}{l}-0.019 \\
(0.094) \\
\mathrm{t} .): \mathrm{Q}[0.25\end{array}$ & $\begin{array}{l}0.064 \\
(0.133) \\
Q[0.75]\end{array}$ & $\begin{array}{l}-0.314 \\
(0.246) \\
1.58\end{array}$ & & $\begin{array}{l}-0.156 \\
(0.108)\end{array}$ & $\begin{array}{l}-0.084 \\
(0.161)\end{array}$ & $\begin{array}{l}-0.341 \\
(0.275) \\
2.66\end{array}$ & & $\begin{array}{l}-0.133 \\
(0.097)\end{array}$ & $\begin{array}{l}-0.084 \\
(0.151)\end{array}$ & $\begin{array}{l}-0.328 \\
(0.225) \\
2.07\end{array}$ & \\
\hline Islamic & $\begin{array}{l}-0.603 \\
(4.481)\end{array}$ & $\begin{array}{l}1.15 \\
(5.174)\end{array}$ & $\begin{array}{l}17.74 * \\
(9.547)\end{array}$ & & $\begin{array}{l}1.182 \\
(0.31)\end{array}$ & $\begin{array}{l}-0.569 \\
(-0.10)\end{array}$ & $\begin{array}{l}17.16 \\
(1.67)\end{array}$ & & $\begin{array}{l}0.419 \\
(0.10)\end{array}$ & $\begin{array}{l}0.14 \\
(0.02)\end{array}$ & $\begin{array}{l}18.28 \\
(0.75)\end{array}$ & \\
\hline $\begin{array}{l}\text { Liquid assets to total } \\
\text { deposits }\left[\vartheta_{\text {LIQ }}\right]\end{array}$ & $\begin{array}{l}0.07 * * \\
(0.029)\end{array}$ & $\begin{array}{l}0.154^{* * *} * \\
(0.057)\end{array}$ & $\begin{array}{l}0.159 * * * \\
(0.051)\end{array}$ & & $\begin{array}{l}0.07 \\
(1.93)\end{array}$ & $\begin{array}{l}0.138 * * \\
(2.81)\end{array}$ & $\begin{array}{l}0.195^{*} \\
(2.26)\end{array}$ & & $\begin{array}{l}0.058 \\
(1.44)\end{array}$ & $\begin{array}{l}0.149 * * \\
(3.15)\end{array}$ & $\begin{array}{l}0.213^{*} \\
(2.36)\end{array}$ & \\
\hline $\begin{array}{l}\text { Liquid assets to total } \\
\text { deposits } \times \text { Islamic }\left[\vartheta_{\text {inter }}^{*}\right] \\
\vartheta_{\text {LIQ }}: \text { Wald test }(\mathrm{p} \text {-value }):\end{array}$ & $\begin{array}{c}-0.036 \\
(0.170) \\
25]=\mathrm{Q}[0 .\end{array}$ & $\begin{array}{l}0.022 \\
(0.095)\end{array}$ & $\begin{array}{l}-0.068 \\
(0.079) \\
1.04\end{array}$ & 2560 & $\begin{array}{l}-0.109 \\
(-0.86)\end{array}$ & $\begin{array}{l}0.014 \\
(0.09)\end{array}$ & $\begin{array}{l}-0.119 \\
(-0.45) \\
\text { N/A }\end{array}$ & 2105 & $\begin{array}{l}-0.094 \\
(-0.67)\end{array}$ & $\begin{array}{l}-0.015 \\
(-0.09)\end{array}$ & $\begin{array}{l}-0.149 \\
(-0.17) \\
\text { N/A }\end{array}$ & 2046 \\
\hline \multicolumn{13}{|c|}{ The impact of higher liquidity on Islamic banks' efficiency $\left[\beta_{\mathrm{LIQ}}+\beta_{\text {inter }}\right]$ compared to conventional banks [ $\left.\beta_{\mathrm{LIQ}}\right]$} \\
\hline$\vartheta_{\mathrm{LIQ}}+\vartheta_{\text {inter }}^{*}: \mathrm{V}$ & $\begin{array}{l}0.034 \\
(0.168) \\
\text { t.): Q }[0.25\end{array}$ & $\begin{array}{l}0.176^{* *} \\
(0.085) \\
Q[0.75]\end{array}$ & $\begin{array}{l}0.089 \\
(0.071) \\
0.17\end{array}$ & & $\begin{array}{l}-0.038 \\
(0.126)\end{array}$ & $\begin{array}{l}0.152 \\
(0.144)\end{array}$ & $\begin{array}{l}0.075 \\
(0.259) \\
\text { N/A }\end{array}$ & & $\begin{array}{l}-0.037 \\
(0.139)\end{array}$ & $\begin{array}{l}0.133 \\
(0.180)\end{array}$ & $\begin{array}{l}0.064 \\
(0.875) \\
\text { N/A }\end{array}$ & \\
\hline
\end{tabular}

Note: This table documents the capital and the liquidity determinants of efficiency by comparing Islamic and conventional banks using conditional quantile regressions for the period from 2005 to 2012. The dependent variable is pure technical efficiency (loan loss provision) computed by comparing banks to a common efficiency frontier. All models use loan loss provision to control for bank risk in bank input. Models (7) to (9) re-estimate efficiency scores (loan loss provision) after excluding the United Kingdom while Models (10) to (12) re-estimate efficiency scores after excluding both the United Kingdom and Singapore from the sample. In this table, we only present the main independent variables to save space. BC, CC, CFE, and YFE are included but not reported. We present the 25th, 50th, and 75th quantile of the dependent variable. Standard errors are clustered at the bank level and are reported in parentheses below their coefficient estimates. *,

$* *$, and $* * *$ represent significance at the $10 \%, 5 \%$, and $1 \%$ level, respectively. 


\section{Figures}

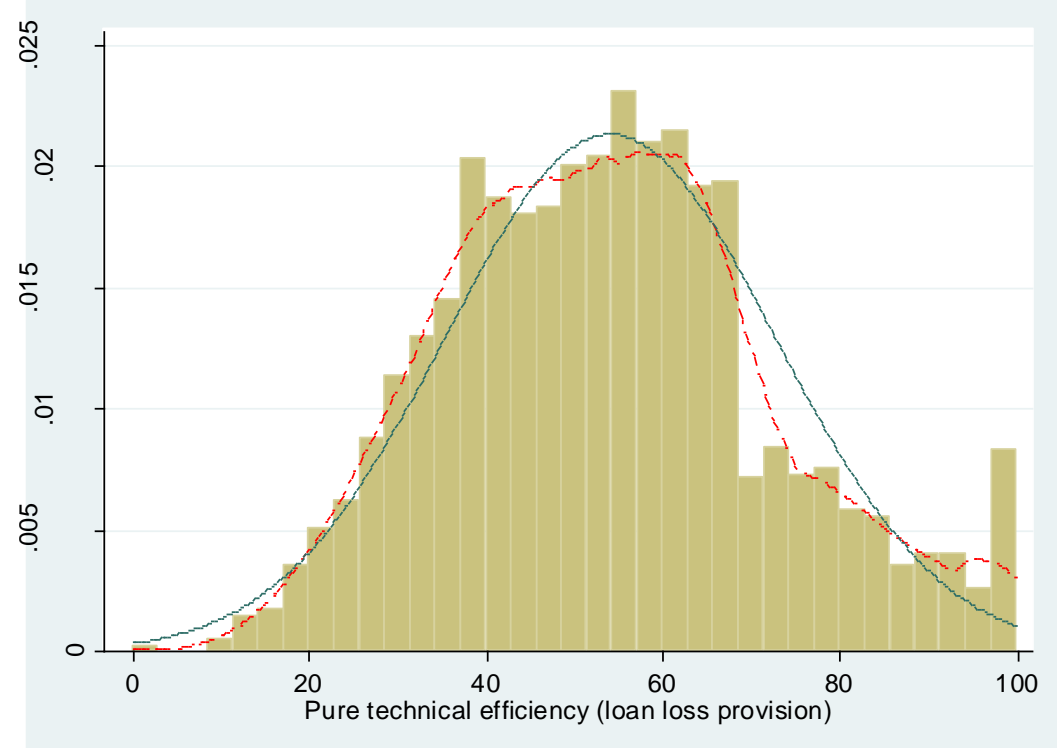

Figure 1. Unconditional distribution of the dependent variable. The solid green line represents a normal distribution while the red dashed line represents the distribution of the efficiency measure we use in our study.

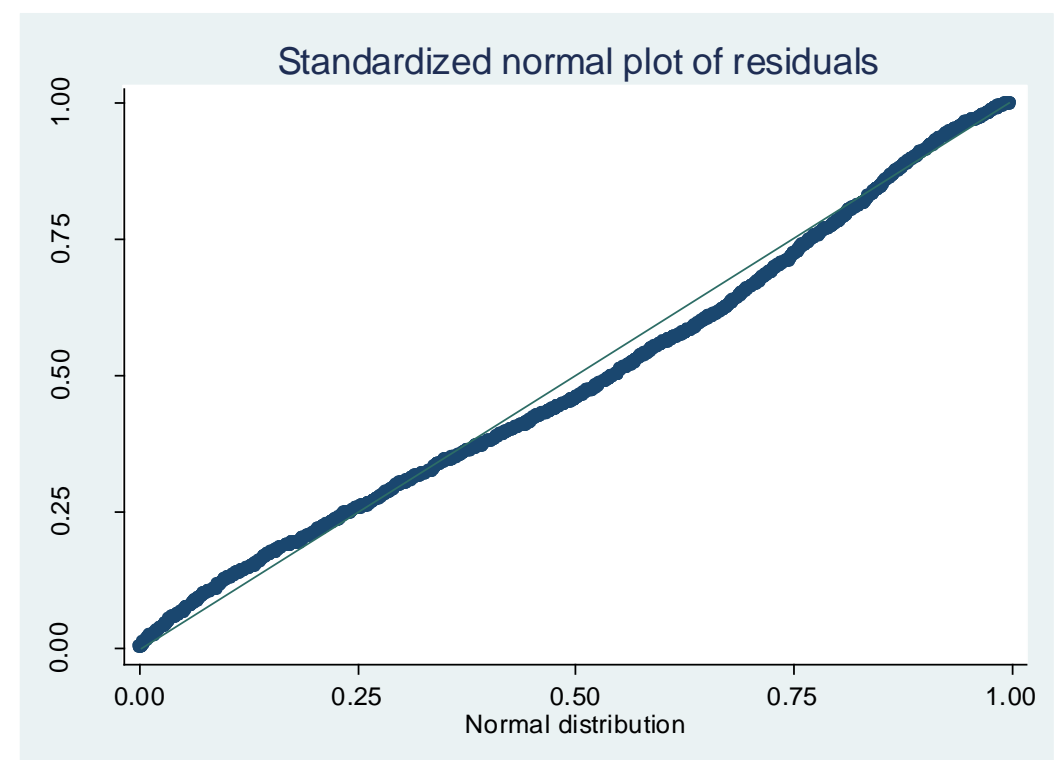

Figure 2. Distribution of standard errors. The thin blue line represents a normal distribution of standard errors while the thick blue line represents the distribution of standard errors from our study. 


\section{Appendix}

\section{Table A1}

Variable definitions and data sources

\begin{tabular}{|c|c|c|}
\hline Variable & Definition & Data Source \\
\hline \multicolumn{3}{|l|}{ Efficiency model } \\
\hline \multicolumn{3}{|l|}{ Outputs of banks } \\
\hline Total loans & Loans and total other lending (US\$ thousands) & Bankscope \\
\hline $\begin{array}{l}\text { Other earning } \\
\text { assets }\end{array}$ & Total other earning assets (US\$ thousands) & Bankscope \\
\hline $\begin{array}{l}\text { Other operating } \\
\text { income }\end{array}$ & Other operating income (US\$ thousands) & Bankscope \\
\hline \multicolumn{3}{|l|}{ Inputs of banks } \\
\hline $\begin{array}{l}\text { Deposits and short } \\
\text { term funding }\end{array}$ & The sum of deposits and short term funding (US\$ thousands) & Bankscope \\
\hline Fixed assets & Fixed assets (US\$ thousands) & Bankscope \\
\hline Overheads & Overhead (US\$ thousands) & Bankscope \\
\hline $\begin{array}{l}\text { Loan loss } \\
\text { provision }\end{array}$ & Loan loss provisions (US\$ thousands) & Bankscope \\
\hline \multicolumn{3}{|l|}{ Dependent variable } \\
\hline Efficiency & $\begin{array}{l}\text { Bank pure technical efficiency, ranging between } 0 \text { and } 100 \text {. It is calculated by comparing each bank } \\
\text { category (i.e. Islamic and conventional banks) to its own efficiency frontier. Efficiency includes } \\
\text { loan loss provisions to control for risk }\end{array}$ & Authors' calculations \\
\hline \multicolumn{3}{|c|}{ Independent variables } \\
\hline \multicolumn{3}{|c|}{ Regulatory variables } \\
\hline Capital adequacy & $\begin{array}{l}\text { The capital adequacy ratio. It is the sum of bank Tier } 1 \text { plus Tier } 2 \text { capital as a percentage of risk } \\
\text { weighted assets. This includes subordinated debt, hybrid capital, loan loss reserves, and valuation } \\
\text { reserves as a percentage of risk weighted assets and off-balance sheet risks. This ratio must be } \\
\text { maintained at a level of at least } 8 \% \text { under Basel II rules. }\end{array}$ & $\begin{array}{l}\text { Bankscope and } \\
\text { banks' annual } \\
\text { reports }\end{array}$ \\
\hline Tier 1 capital & $\begin{array}{l}\text { Similar to the capital adequacy ratio. This measure of capital adequacy measures Tier } 1 \text { capital } \\
\text { divided by risk weighted assets computed under the Basel rules. Banks must maintain a minimum } \\
\text { Tier } 1 \text { capital of } 4 \% \text {. }\end{array}$ & $\begin{array}{l}\text { Bankscope and } \\
\text { banks' annual } \\
\text { reports }\end{array}$ \\
\hline $\begin{array}{l}\text { Shareholders' } \\
\text { equity }\end{array}$ & The traditional leverage ratio measured as the ratio of equity to assets times 100 . & Bankscope \\
\hline \multicolumn{3}{|l|}{ 2. Liquidity ratios } \\
\hline Maturity match & $\begin{array}{l}\text { The ratio of liquid assets to deposits and short term funding. It measures and assesses the sensitivity } \\
\text { to bank runs; therefore, it promotes financial soundness, but it can also be interpreted as excess of } \\
\text { liquidity coverage. }\end{array}$ & Bankscope \\
\hline $\begin{array}{l}\text { Liquid assets to } \\
\text { assets }\end{array}$ & $\begin{array}{l}\text { The ratio of liquid assets to total assets. The ratio measures assets that are easily convertible to cash } \\
\text { at any time and without any constraints. }\end{array}$ & Bankscope \\
\hline $\begin{array}{l}\text { Liquid assets to } \\
\text { total deposits }\end{array}$ & $\begin{array}{l}\text { The ratio of liquid assets to total deposits and borrowing. Similar to the liquid assets to deposit and } \\
\text { short term funding ratio, this ratio considers the amount of liquid assets available not only for } \\
\text { depositors but also for borrowers. }\end{array}$ & Bankscope \\
\hline \multicolumn{3}{|l|}{ Control variables } \\
\hline \multicolumn{3}{|c|}{ Bank control variables } \\
\hline Size & The natural logarithm of total assets & Bankscope \\
\hline Tangibility & The ratio of bank fixed assets to total assets times 100 & Bankscope \\
\hline $\begin{array}{l}\text { Activity } \\
\text { diversification }\end{array}$ & The share of bank net loans in total earning assets times 100 & Bankscope \\
\hline ROAA & $\begin{array}{l}\text { The profitability ratio is a measure of bank profitability at the operational level. It reports the } \\
\text { amount of a bank's net income divided by average total assets times } 100 .\end{array}$ & Bankscope \\
\hline CIR & The share of bank costs to bank income before provisions times 100 & Bankscope \\
\hline OVERTA & The percentage of bank overhead to total assets & \\
\hline \multicolumn{3}{|c|}{ Country control variables } \\
\hline GDP per capita & The natural logarithm of GDP per capita & $\begin{array}{l}\text { World Development } \\
\text { Indicators (WDI) }\end{array}$ \\
\hline GDP growth & Growth rate of GDP & $\begin{array}{l}\text { World Development } \\
\text { Indicators (WDI) }\end{array}$ \\
\hline Inflation & Inflation rate, based on changes in the consumer price index & $\begin{array}{l}\text { World Development } \\
\text { Indicators (WDI) }\end{array}$ \\
\hline LEGAL & $\begin{array}{l}\text { A variable that takes on a value of } 0 \text { if a country does not apply Shari'a rules in its legal system, a } \\
\text { value of } 1 \text { if Shari'a law and other legal systems are considered, and a value of } 2 \text { if Shari'a is the } \\
\text { only accepted law }\end{array}$ & $\begin{array}{l}\text { The CIA World Fact } \\
\text { Book }\end{array}$ \\
\hline GLOBAL & A dummy variable that equals 1 for the years 2008 and 2009 and 0 otherwise & Authors' calculation \\
\hline Arab Spring & A dummy variable that equals 1 if a country is affected by the Arab Spring and 0 otherwise & $\begin{array}{l}\text { Ghosh (2016), Bitar } \\
\text { et al. (2017b) }\end{array}$ \\
\hline Islamic & A dummy variable that equals 1 for Islamic banks and 0 otherwise & Authors' calculation \\
\hline
\end{tabular}


Table A2

Correlation matrix

\begin{tabular}{|c|c|c|c|c|c|c|c|c|c|c|c|c|c|c|c|c|c|}
\hline & 1 & 2 & 3 & 4 & 5 & 6 & 7 & 8 & 9 & 10 & 11 & 12 & 13 & 16 & 17 & 18 & 19 \\
\hline (1) Tier1 capital & 1.00 & & & & & & & & & & & & & & & & \\
\hline (2) Capital adequacy & $0.98^{\mathrm{c}}$ & 1.00 & & & & & & & & & & & & & & & \\
\hline (3) Shareholders' equity & $0.69^{\mathrm{c}}$ & $0.67^{\mathrm{c}}$ & 1.00 & & & & & & & & & & & & & & \\
\hline (4) Maturity match & $0.47^{\mathrm{c}}$ & $0.48^{\mathrm{c}}$ & $0.62^{\mathrm{c}}$ & 1.00 & & & & & & & & & & & & & \\
\hline $\begin{array}{l}\text { (5) Liquid assets to } \\
\text { assets }\end{array}$ & $0.34^{\mathrm{c}}$ & $0.33^{\mathrm{c}}$ & $0.20^{\mathrm{c}}$ & $0.51^{\mathrm{c}}$ & 1.00 & & & & & & & & & & & & \\
\hline $\begin{array}{l}\text { (6) Liquid assets to total } \\
\text { deposits }\end{array}$ & $0.42^{\mathrm{c}}$ & $0.49^{\mathrm{c}}$ & $0.56^{\mathrm{c}}$ & $0.74^{\mathrm{c}}$ & $0.78^{\mathrm{c}}$ & 1.00 & & & & & & & & & & & \\
\hline (7) Size & $-0.42^{\mathrm{c}}$ & $-0.38^{c}$ & $-0.46^{c}$ & $-0.27^{\mathrm{c}}$ & $-0.26^{c}$ & $-0.26^{\mathrm{c}}$ & 1.00 & & & & & & & & & & \\
\hline (8) Tangibility & $0.17^{\mathrm{c}}$ & $0.11^{\mathrm{c}}$ & $0.27^{\mathrm{c}}$ & $0.11^{\mathrm{c}}$ & $-0.07^{\mathrm{c}}$ & $-0.03^{\mathrm{a}}$ & $-0.31^{c}$ & 1.00 & & & & & & & & & \\
\hline $\begin{array}{l}\text { (9) Loans to earning } \\
\text { assets }\end{array}$ & $-0.25^{c}$ & $-0.24^{c}$ & $-0.17^{c}$ & $-0.38^{c}$ & $-0.59^{c}$ & $-0.46^{c}$ & $0.19^{\mathrm{c}}$ & $-0.10^{c}$ & 1.00 & & & & & & & & \\
\hline (10) ROAA & 0.00 & 0.03 & $0.11^{\mathrm{c}}$ & $-0.08^{c}$ & $-0.03^{\mathrm{b}}$ & $-0.06^{\mathrm{c}}$ & 0.02 & $-0.08^{c}$ & $0.10^{\mathrm{c}}$ & 1.00 & & & & & & & \\
\hline (11) CIR & $0.20^{\mathrm{c}}$ & $0.17^{\mathrm{c}}$ & $0.16^{\mathrm{c}}$ & $0.16^{\mathrm{c}}$ & $0.08^{\mathrm{c}}$ & $0.13^{\mathrm{c}}$ & $-0.26^{\mathrm{c}}$ & $0.23^{\mathrm{c}}$ & $-0.18^{\mathrm{c}}$ & $-0.52^{\mathrm{c}}$ & 1.00 & & & & & & \\
\hline (12) OVERTA & $0.22^{\mathrm{c}}$ & $0.19^{\mathrm{c}}$ & $0.34^{\mathrm{c}}$ & $0.17^{\mathrm{c}}$ & $-0.06^{\mathrm{c}}$ & 0.02 & $-0.43^{c}$ & $0.46^{\mathrm{c}}$ & $-0.03^{b}$ & $-0.10^{\mathrm{c}}$ & $0.45^{\mathrm{c}}$ & 1.00 & & & & & \\
\hline (13) Efficiency (LLP) & $0.05^{\mathrm{b}}$ & $0.09^{\mathrm{c}}$ & $0.21^{\mathrm{c}}$ & $0.19^{\mathrm{c}}$ & 0.02 & $0.05^{\mathrm{b}}$ & $0.27^{\mathrm{c}}$ & $-0.17^{c}$ & -0.02 & $0.18^{c}$ & $-0.20^{c}$ & $-0.24^{c}$ & 1.00 & & & & \\
\hline (16) Legal system & $0.05^{\mathrm{b}}$ & 0.01 & $0.05^{\mathrm{b}}$ & $-0.04^{b}$ & $-0.17^{c}$ & $-0.10^{c}$ & $0.03^{\mathrm{b}}$ & $0.16^{\mathrm{c}}$ & $0.16^{\mathrm{c}}$ & $0.07^{\mathrm{c}}$ & $-0.10^{c}$ & $-0.04^{\mathrm{b}}$ & $0.09^{\mathrm{c}}$ & 1.00 & & & \\
\hline (17) GDP per capita & $0.09^{\mathrm{c}}$ & $0.07^{\mathrm{b}}$ & $0.15^{\mathrm{c}}$ & $0.09^{\mathrm{c}}$ & $0.14^{\mathrm{c}}$ & $0.14^{\mathrm{c}}$ & $0.29^{\mathrm{c}}$ & $-0.24^{\mathrm{c}}$ & $-0.06^{\mathrm{c}}$ & -0.01 & -0.03 & $-0.23^{c}$ & $0.38^{\mathrm{c}}$ & $-0.32^{c}$ & 1.00 & & \\
\hline (18) GDP growth & 0.03 & 0.01 & 0.00 & $-0.06^{\mathrm{c}}$ & $-0.11^{c}$ & $-0.07^{\mathrm{c}}$ & -0.01 & 0.01 & $0.10^{\mathrm{c}}$ & $0.15^{\mathrm{c}}$ & $-0.12^{\mathrm{c}}$ & -0.02 & $-0.03^{\mathrm{a}}$ & $0.16^{\mathrm{c}}$ & $-0.21^{\mathrm{c}}$ & 1.00 & \\
\hline (19) Inflation & $-0.09^{\mathrm{c}}$ & $-0.06^{\mathrm{c}}$ & $-0.07^{\mathrm{c}}$ & $-0.07^{\mathrm{c}}$ & $-0.12^{c}$ & $-0.12^{\mathrm{c}}$ & $-0.08^{c}$ & $0.19^{\mathrm{c}}$ & $0.05^{\mathrm{b}}$ & $0.05^{\mathrm{b}}$ & 0.01 & $0.12^{\mathrm{c}}$ & $-0.14^{c}$ & $0.25^{\mathrm{c}}$ & $-0.41^{\mathrm{c}}$ & $-0.06^{\mathrm{c}}$ & 1.00 \\
\hline
\end{tabular}

$\frac{(19) \text { Inflation }}{{ }^{\mathrm{a}} \mathrm{b},}$, and $^{\mathrm{c}}$ represent significance at the $10 \%, 5 \%$, and $1 \%$ level, respectively 